\title{
Isotopic Ages and Stratigraphy of Cenozoic Rocks of the Marysvale Volcanic Field and Adjacent Areas, West-Central Utah
}

\section{U.S. GEOLOGICAL SURVEY BULLETIN 2071}

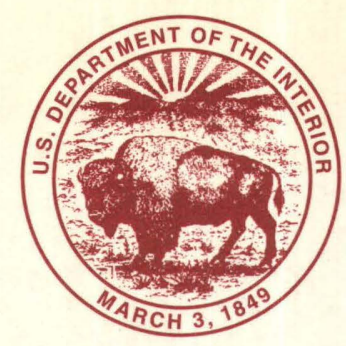




\section{AVAILABILITY OF BOOKS AND MAPS OF THE U.S. GEOLOGICAL SURVEY}

Instructions on ordering publications of the U.S. Geological Survey, along with prices of the last offerings, are given in the current-year issues of the monthly catalog "New Publications of the U.S. Geological Survey." Prices of available U.S. Geological Survey publications released prior to the current year are listed in the most recent annual "Price and Availability List." Publications that may be listed in various U.S. Geological Survey catalogs (see back inside cover) but not listed in the most recent annual "Price and Availability List" may no longer be available.

Reports released through the NTIS may be obtained by writing to the National Technical Information Service, U.S. Department of Commerce, Springfield, VA 22161; please include NTIS report number with inquiry.

Order U.S. Geological Survey publications by mail or over the counter from the offices listed below.

\section{BY MAIL}

\section{Books}

Professional Papers, Bulletins, Water-Supply Papers, Techniques of Water-Resources Investigations, Circulars, publications of general interest (such as leaflets, pamphlets, booklets), single copies of Earthquakes \& Volcanoes, Preliminary Determination of Epicenters, and some miscellaneous reports, including some of the foregoing series that have gone out of print at the Superintendent of Documents, are obtainable by mail from

\section{U.S. Geological Survey, Map Distribution Box 25286, MS 306, Federal Center Denver, CO 80225}

Subscriptions to periodicals (Earthquakes \& Volcanoes and Preliminary Determination of Epicenters) can be obtained ONLY from the

\section{Superintendent of Documents Government Printing Office \\ Washington, DC 20402}

(Check or money order must be payable to Superintendent of Documents.)

\section{Maps}

For maps, address mail orders to

\section{U. S. Geological Survey, Map Distribution Box 25286, Bldg. 810, Federal Center Denver, CO 80225}

Residents of Alaska may order maps from

\section{U.S. Geological Survey, Earth Science Information Center 101 Twelfth Ave., Box 12 Fairbanks, AK 99701}

\section{OVER THE COUNTER}

\section{Books and Maps}

Books and maps of the U.S. Geological Survey are available over the counter at the following U.S. Geological Survey offices, all of which are authorized agents of the Superintendent of Documents.

- ANCHORAGE, Alaska-Rm. 101, 4230 University Dr.

- LAKEWOOD, Colorado-Federal Center, Bldg. 810

- MENLO PARK, California-Bldg. 3, Rm. 3128, 345 Middlefield Rd.

- RESTON, Virginia-USGS National Center, Rm. 1C402, 12201 Sunrise Valley Dr.

- SALT LAKE CITY, Utah-Federal Bldg., Rm. 8105, 125 South State St.

- SPOKANE, Washington-U.S. Post Office Bldg., Rm. 135, West 904 Riverside Ave.

- WASHINGTON, D.C.-Main Interior Bldg., Rm. 2650, 18th and C Sts., NW.

\section{Maps Only}

Maps may be purchased over the counter at the following U.S. Geological Survey offices:

- FAIRBANKS, Alaska-New Federal Bldg, 101 Twelfth Ave.

- ROLLA, Missouri-1400 Independence Rd.

- STENNIS SPACE CENTER, Mississippi-Bldg. 3101 


\section{Isotopic Ages and Stratigraphy of Cenozoic Rocks of the Marysvale Volcanic Field and Adjacent Areas, West-Central Utah}

By Peter D. Rowley, Harald H. Mehnert, Charles W. Naeser, Lawrence W. Snee, Charles G. Cunningham, Thomas A. Steven, John J. Anderson, Edward G. Sable, and R. Ernest Anderson

U.S. GEOLOGICAL SURVEY BULLETIN 2071

An update of the Cenozoic stratigraphy of the Marysvale volcanic field, based on new and published $K$-Ar, fission-track, and ${ }^{40} \mathrm{Ar}{ }^{\beta 9} \mathrm{Ar}$ ages on igneous rocks

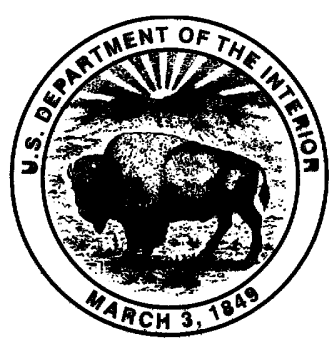




\title{
U.S. DEPARTMENT OF THE INTERIOR BRUCE BABBITT, Secretary
}

\author{
U.S. GEOLOGICAL SURVEY \\ Gordon P. Eaton, Director
}
For Sale by U.S. Geological Survey, Map Distribution Box 25286, MS 306, Federal Center Denver, CO 80225

\begin{abstract}
Any use of trade, product, or firm names in this publication is for descriptive purposes only and does not imply endorsement by the U.S. Government
\end{abstract}

\section{Library of Congress Cataloging-in-Publication Data}

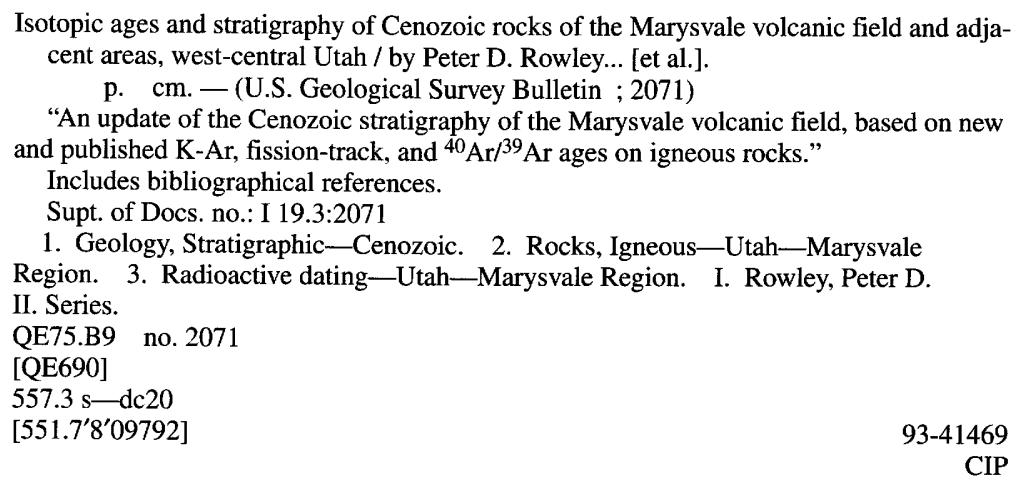




\section{CONTENTS}

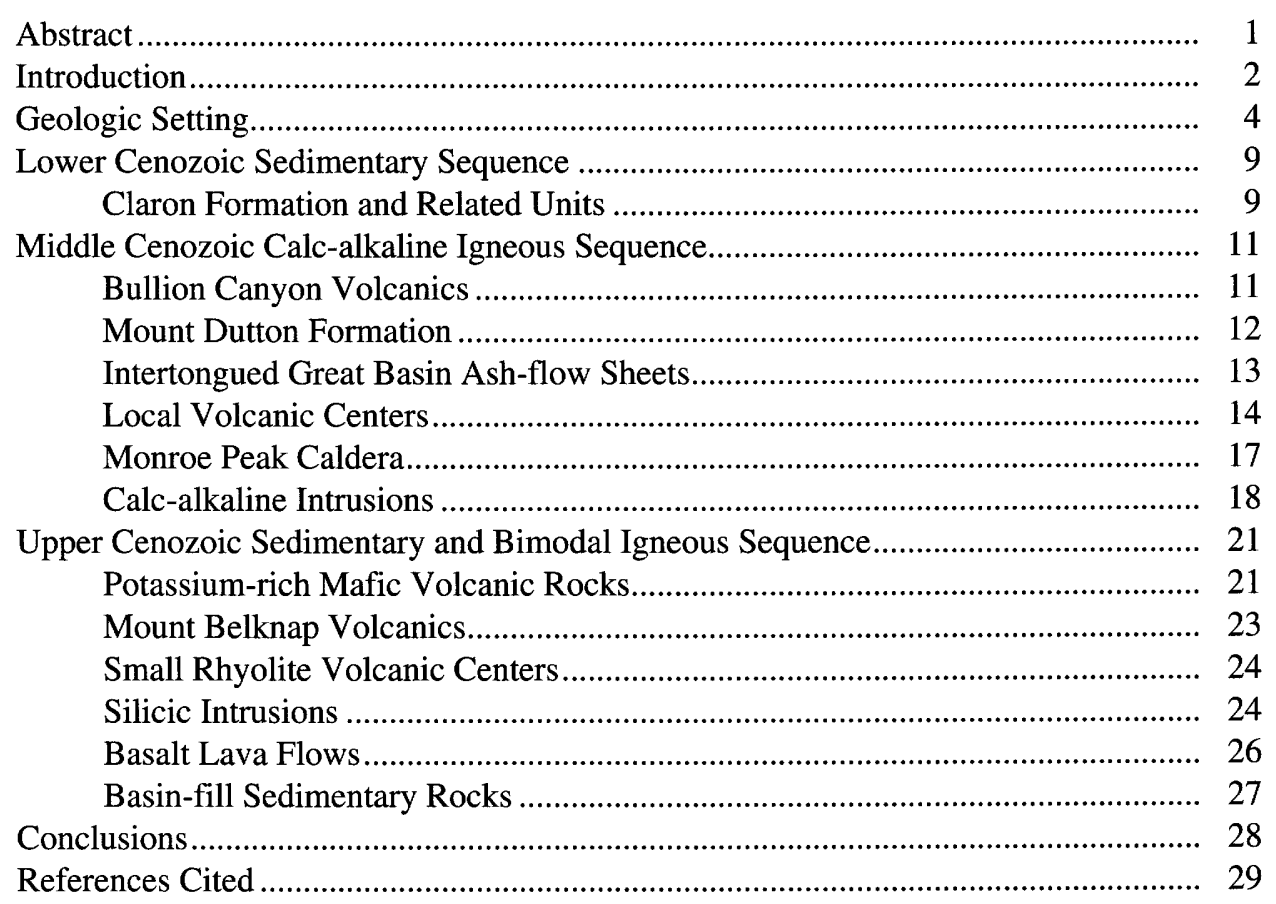

\section{FIGURES}

1. Index map showing location of the Marysvale volcanic field, Utah ......................................................................

2. Composite stratigraphic column of Cenozoic rocks in and near the Marysvale volcanic field ................................. 5

3. Generalized geologic map, showing locality of samples whose ages and analytical data are reported here ................ 7

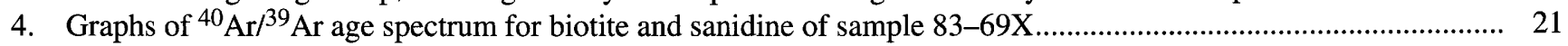

\section{TABLES}

1. Data for potassium-argon dates, Marysvale volcanic field and adjacent areas, Utah ........................................ 10

2. Data for fission-track dates, Marysvale volcanic field and adjacent areas, Utah .................................................. 18

3. Data for ${ }^{40} \mathrm{Ar} /{ }^{39} \mathrm{Ar}$ dates for biotite and sanidine from sample 83-69X, eastern Sevier Plateau, Utah...................... 20 


\title{
Isotopic Ages and Stratigraphy of Cenozoic Rocks of the Marysvale Volcanic Field and Adjacent Areas, West-Central Utah
}

\author{
By Peter D. Rowley, Harald H. Mehnert, Charles W. Naeser, Lawrence W. Snee, \\ Charles G. Cunningham, Thomas A. Steven, John J. Anderson, ${ }^{1}$ \\ Edward G. Sable, and R. Ernest Anderson
}

ABSTRACT

\begin{abstract}
The Marysvale volcanic field lies at the east end of the east-northeast-trending Pioche-Marysvale igneous belt, the site of extensive Cenozoic volcanism and mineralization above a major batholith complex. The field is mostly in the High Plateaus transition zone between the Great Basin and the main part of the Colorado Plateau. Cenozoic rocks of the Marysvale field can be divided into three main sequences: (1) lower Cenozoic (Paleocene through Oligocene) fluviallacustrine sedimentary rocks (mostly the Claron Formation) that overlie Paleozoic and Mesozoic rocks with angular unconformity; (2) thick, middle Cenozoic (Oligocene and lower Miocene, 34? to $22 \mathrm{Ma}$ ), intermediate-composition, predominantly calc-alkaline volcanic rocks and related source intrusions; and (3) upper Cenozoic (23 Ma to Quaternary), compositionally bimodal (basalt and high-silica rhyolite) volcanic rocks, local source intrusions associated with these bimodal rocks, and overlying and intertongued clastic basin-fill sedimentary rocks. The overall volume of volcanic rocks in the field is at least $12,000 \mathrm{~km}^{3}$, of which about 95 percent is calc-alkaline and 5 percent is part of a bimodal assemblage. More than 90 percent of the volume of Marysvale volcanic rocks consists of lava flows, volcanic mudflow breccia, and flow breccia, and less than 10 percent consists of tuff.
\end{abstract}

The lower Cenozoic sequence consists of continental sedimentary rocks that are locally tuffaceous. Most of the sedimentary rocks in the Marysvale volcanic field have been mapped as the upper Paleocene to Oligocene Claron Formation, but new stratigraphic studies are currently redefining the sequence. Airfall tuffs in the upper part of the sedimentary sequence have isotopic ages as old as $34 \mathrm{Ma}$, and most of these tuffs probably represent early eruptions from the Marysvale field.

${ }^{1}$ John J. Anderson, Dept. of Geology, Kent State University, Kent, Ohio 44242.
The middle Cenozoic calc-alkaline rocks centered in the northern and central Tushar Mountains and northern Sevier Plateau are mostly relatively highly evolved dacite and subordinate andesite called the Bullion Canyon Volcanics, deposited between about 34 ? and $22 \mathrm{Ma}$. Deposits from volcanic centers that intertongue on the north include the andesitic to dacitic volcanic rocks of Dog Valley and the overlying andesitic to dacitic volcanic rocks of Wales Canyon. Deposits from volcanic centers that intertongue on the east include the andesitic volcanic rocks of Signal Peak, the andesitic volcanic rocks of Little Table, the dacitic volcanic rocks of Willow Spring, and the dacitic volcanic rocks of Langdon Mountain. Large, shallow, intermediate-composition consanguineous intrusions were emplaced into the flanks and cores of the major volcano complexes late during Bullion Canyon volcano evolution. Failure of the cover rocks above some of these shallow intrusions resulted in eruption of ash-flow tuffs and subsidence of the source areas to form calderas. Two tuff members in the Bullion Canyon Volcanics, the 27-Ma Three Creeks Tuff Member and the 24-Ma Delano Peak Tuff Member, came from calderas in the southern Pavant Range and southern Tushar Mountains, respectively. Bullion Canyon volcanism was largely terminated by eruption of the Osiris Tuff at about $23 \mathrm{Ma}$ in the Marysvale area and northern Sevier Plateau, resulting in the large Monroe Peak caldera. Hydrothermally altered rocks and deposits of base and precious metals formed during Bullion Canyon magmatism in the Tushar Mountains and Sevier Valley.

In contrast to the moderately evolved rocks in the center of the Marysvale field, the middle Cenozoic rocks in the southern part of the field are less evolved andesite and dacite, containing small sparse phenocrysts. Most rocks of the southern part of the field belong to the 34?- to 21-Ma Mount Dutton Formation, a thick sequence that intertongues to its north with the Bullion Canyon Volcanics and other units. The Mount Dutton Formation contains several tuff members 
whose sources probably were in the northern Marysvale field. Shallow, 26-20?-Ma calc-alkaline laccoliths unrelated to Mount Dutton magmatism were emplaced into lower parts of the Claron Formation in the northern Markagunt Plateau, mostly south of the Mount Dutton source volcanoes. Some of these laccoliths erupted to form dacitic lava flows and ashflow tuff. The laccoliths were fed from a batholith complex that underlay the southern flank of the Marysvale volcanic field; this complex is at the east end of the Delamar-Iron Springs igneous belt, an east-northeast-trending belt south of and parallel to the Pioche-Marysvale igneous belt.

The beginning of late Cenozoic bimodal (basalt and high-silica rhyolite) magmatism overlapped in time with the termination of calc-alkaline magmatism. The switch to bimodal magmatism corresponded with an increase in eastwest extension and the progressive decrease and final cessation of subduction under much of the western United States. Bimodal magmatism generally began with potassium-rich mafic volcanic rocks that began to be erupted 23-21 Ma from small local centers scattered throughout the Marysvale field. The main mass of bimodal rocks, however, is high-silica rhyolite of the Mount Belknap Volcanics, which formed from 22 to 14 Ma. The Mount Belknap Volcanics consist mostly of ash-flow tuff, lava flows, flow breccia, and intrusions derived from an eastern source area in the Antelope Range and southeastern Tushar Mountains and a western source area in the central Tushar Mountains. The western source area includes the Mount Belknap caldera that erupted the Joe Lott Tuff Member (19 Ma) of the Mount Belknap Volcanics. Hydrothermally altered rocks and associated vein alunite deposits and lithophile-element mineral deposits such as uranium and molybdenum formed during Mount Belknap magmatism. Small centers of high-silica rhyolite domes and lava flows as young as $0.5 \mathrm{Ma}$ are scattered elsewhere in the volcanic field. Basalt lava flows and cones with normal potassium contents were erupted from $16 \mathrm{Ma}$ to Quaternary time from widely scattered sources in and near the Marysvale field; these are interbedded with basin-fill sedimentary rocks derived largely from erosion of nearby higher areas. The oldest of these sedimentary rocks is about $14 \mathrm{Ma}$, but the main grabens of the Great Basin and transition zone probably did not start to form until about $10 \mathrm{Ma}$, when the episode of basin-range extension began. In the area of the Marysvale volcanic field, the main part of this extensional episode took place between 8 and 5 Ma.

\section{INTRODUCTION}

The Marysvale volcanic field is one of the major Cenozoic volcanic fields in the western United States (fig. 1). Most of the field is in the High Plateaus subprovince of the Colorado Plateaus province, a transition zone between the Great Basin and the stable, main part of the Colorado
Plateau. Part of the field extends into the Great Basin as in the Mineral Mountains and the east half of the Black Mountains. The Marysvale field lies at the east end of the east-northeast-trending Pioche-Marysvale igneous belt, the site of extensive Tertiary volcanism and mineralization above a major batholith complex; thus igneous rocks of the same general types and ages as in the Marysvale field extend west and west-southwest along the belt from west of the Mineral Mountains into Nevada. East of the Marysvale field, new dates from laccoliths of the Henry, La Sal, and Abajo Mountains of central and southeastern Utah indicate that most intrusive activity there is coeval with that in the Marysvale field (Sullivan and others, 1991; Nelson and others, 1992).

Although investigations of the geology of the Marysvale field began in the late 19th century (for example, Dutton, 1880), detailed studies did not begin until the 1930's and 1940 's, when Callaghan $(1938,1939)$ described the basic stratigraphy during geologic mapping and studies of mineral deposits centered around Marysvale (Callaghan and Parker, 1961a, b, 1962a, b; Willard and Callaghan, 1962). In the 1950 's, P.F. Kerr and his students at Columbia University (Kerr and others, 1957, among others) undertook detailed studies of the uranium deposits in the Marysvale mining district. The reports of these studies included the first isotopic ages of the volcanic rocks and ore deposits (Bassett and others, 1963). A significant development that would prove useful in the Marysvale field was the realization by Mackin (1960), based on studies in the Iron Springs mining district $15 \mathrm{~km}$ west of Cedar City (fig. 1), that many volcanic units in southwestern Utah are regional ash-flow sheets that provide key marker horizons in working out volcanic stratigraphy. Mackin (1960), with help from his students at the Universities of Washington and Texas, set up the basic stratigraphy of these tuff units in the eastern Great Basin, and Armstrong (1970) was the first to determine their K-Ar ages. Two of these students, J.J. Anderson and P.D. Rowley, applied Mackin's concepts to the northern Markagunt Plateau and southern Sevier Plateau beginning in 1963, and developed the first modern stratigraphic framework of the southern part of the Marysvale volcanic field (for example, Anderson and Rowley, 1975); K-Ar ages of numerous units in the same area were determined by Fleck and others (1975). Williams and Hackman (1971) described the basic stratigraphy of the eastern Marysvale field. In 1975, T.A. Steven, C.G. Cunningham, P.D. Rowley, J.J. Anderson, M.G. Best, and others began a major USGS mapping initiative in the heart of the Marysvale field, with special attention directed toward establishing the geologic framework of the widespread mineral resource occurrences. Isotopic dating by H.H. Mehnert and C.W. Naeser established the chronology of the detailed stratigraphy, and many of the ages obtained are given in earlier reports (such as Cunningham and Steven, 1979a; Rowley, Steven, and others, 1979; Steven and others, 1979). The USGS project resulted in more than 200 open-file 


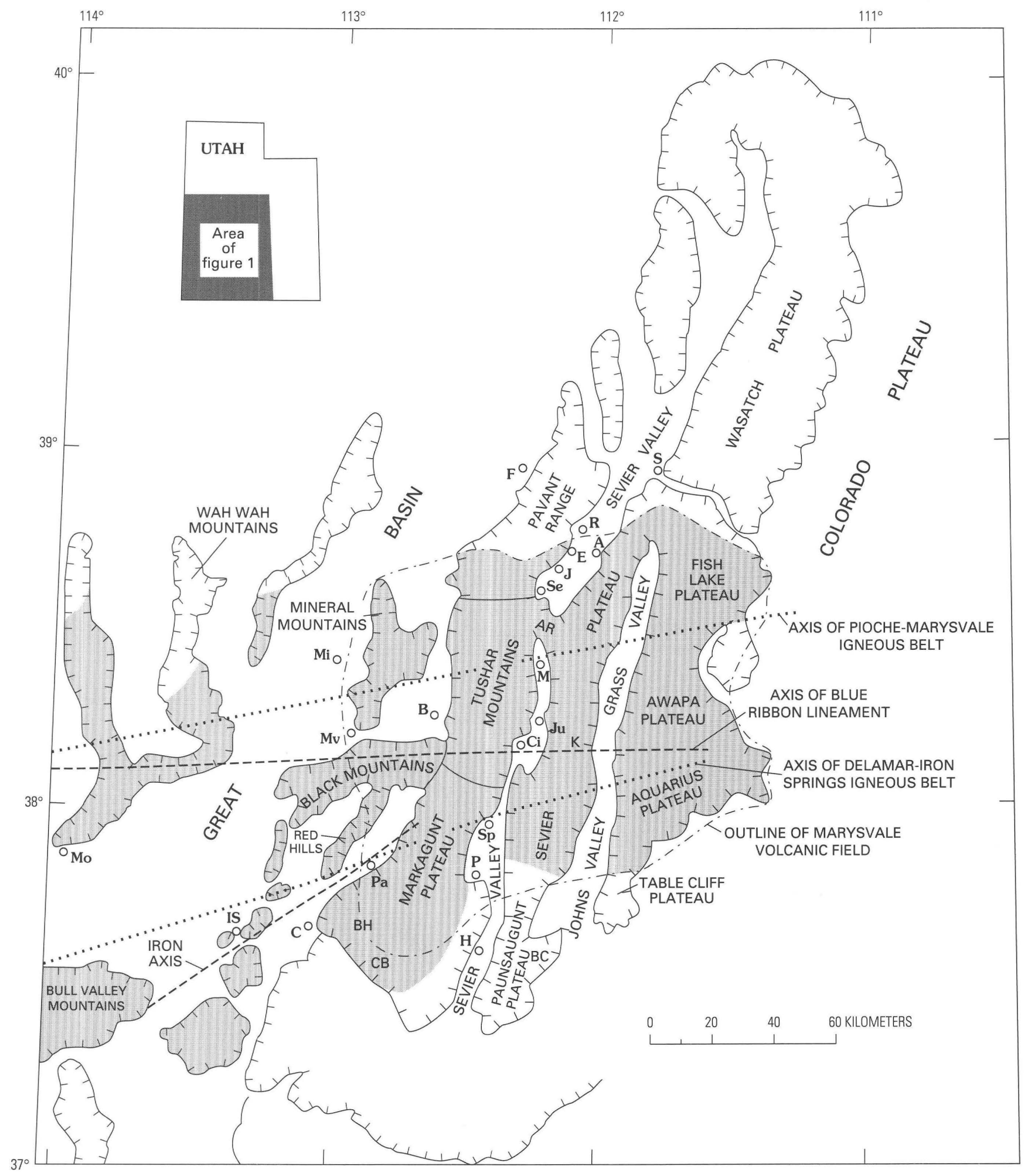

Figure 1. Index map showing location of the Marysvale volcanic field, plateaus and ranges of the High Plateaus, and adjacent areas in Utah, modified from Anderson and Rowley (1975, fig. 1) and Steven and others (1979, fig. 1). A, Annabella; AR, Antelope Range; B, Beaver; BC, Bryce Canyon National Park; BH, Brian Head; C, Cedar City; CB, Cedar Breaks National Monument; Ci, Circleville; E, Elsinore; F, Fillmore; H, Hatch; IS, Iron Springs; J, Joseph; Ju, Junction; K, Kingston Canyon; M, Marysvale; Mi, Milford; Mo, Modena; Mv, Minersville; P, Panguitch; Pa, Parowan; R, Richfield; S, Salina; Se, Sevier; Sp, Spry. Great Basin-Colorado Plateau boundary is just west of the towns of Fillmore, Beaver, Parowan, and Cedar City. Patterned areas are underlain largely by volcanic rocks. 
and published maps and reports, many of which are listed by Steven and Morris (1987). Many of these are detailed $(1: 24,000$ and 1:50,000) geologic maps of the volcanic field. The geology, geophysics, and mineral resources of the main eruptive center were compiled at 1:50,000 scale as USGS IMaps 1430-A through 1430-G (Cunningham and others, 1983; Cunningham, Steven, Rowley, and others, 1984; Cook and others, 1984; Campbell and others, 1984; Miller and others, 1984 a, b, c). Calderas within the volcanic field were discussed by Cunningham and Steven (1979a), Steven (1981), Steven, Rowley, and Cunningham (1984), Steven, Cunningham, and Anderson (1984), and Budding and others (1987). Reports of specific mineral deposits, including their isotopic ages, are given by Cunningham and Steven $(1979 b, c)$, Steven and others (1981), Cunningham and others (1982), Cunningham, Rye, and others (1984), Cunningham, Steven, Campbell, and others (1984), Podwysocki and Segal (1983), Beaty and others (1986), and Steven and Morris (1987). In 1990 , Steven and others published a 1:250,000-scale geologic map showing most of the Marysvale field and much of the rest of the Pioche-Marysvale igneous belt. In a report in progress, Rowley and others discuss the regional tectonic and magmatic setting of the Marysvale field.

This report summarizes what is presently known about the Cenozoic stratigraphy of the Marysvale field, with an emphasis on our estimate of the best ages of the various rock units. We discuss previously published isotopic ages and we publish new ages and analytical data. Most ages are by the K-Ar technique, but fission-track and two ${ }^{40} \mathrm{Ar} /{ }^{39} \mathrm{Ar}$ ages also are reported. The K-Ar method is described by Evernden and Curtis (1965).

The fission-track age of apatite was determined with the population technique, whereas the external detector method was used to date zircons (Naeser, 1976, 1979). Apatite separates were mounted in epoxy, polished, then etched in 7 percent $\mathrm{HNO}_{3}$ at $23{ }^{\circ} \mathrm{C}$ for 40 seconds. Zircon grains were mounted in Teflon and etched in a eutectic melt of $\mathrm{KOH}-$ $\mathrm{NaOH}$ (Gleadow and others, 1976) at $215{ }^{\circ} \mathrm{C}$ for $30-50$ hours. The Teflon mounts were covered with a muscovite detector and irradiated along with neutron dose monitors (Udoped glasses SRM 962 also covered with muscovite detectors) in the USGS reactor at Denver, Colo. The neutron dose was determined using the track density in the muscovite detectors and the $\mathrm{Cu}$ calibration for SRM 962 (Carpenter and Reimer, 1974).

Two new ${ }^{40} \mathrm{Ar} /{ }^{39} \mathrm{Ar}$ mineral ages from a single sample help constrain temporal relationships in the Marysvale volcanic field. The ${ }^{40} \mathrm{Ar} /{ }^{39} \mathrm{Ar}$ isotopic dating method is a variant of the conventional K-Ar method. For ${ }^{40} \mathrm{Ar} /{ }^{39} \mathrm{Ar}$ analysis, samples are irradiated in a nuclear reactor to produce ${ }^{39} \mathrm{Ar}$ from ${ }^{39} \mathrm{~K}$. In this study, 100 -mg samples of sanidine and 63mg samples of biotite were irradiated in the USGS Denver TRIGA reactor for 30 hours at 1 megawatt. Each sample was irradiated adjacent to an aliquant of standard MMhb- 1 hornblende for which $\mathrm{K}=1.555$ percent, ${ }^{40} \mathrm{Ar}_{\mathrm{K}}=1.624 \times 10^{-9}$ $\mathrm{mol} / \mathrm{g}$, and $\mathrm{K}-\mathrm{Ar}$ date=520.4 Ma (Samson and Alexander, 1987). Samples were experimentally degassed in a doublevacuum resistance furnace via step heating in 10-13 steps under ultra-high vacuum for about 20 minutes at each temperature step. The mass $40,39,38,37$, and 36 isotopes of argon were analyzed using a Mass Analyser Products series 215 rare-gas mass spectrometer. Raw isotopic data were corrected for volume, mass discrimination, trap current, radioactive decay of ${ }^{37} \mathrm{Ar}$ and ${ }^{39} \mathrm{Ar}$, and interfering isotopes of argon.

Where necessary, previously determined isotopic ages compiled here have been recalculated using the IUGS decay constants (Steiger and Jäger, 1977). Classifications of volcanic and plutonic rocks are those of IUGS (Le Bas and others, 1986, and Streckeisen, 1976, respectively). We have not attempted in this report to review comprehensively the voluminous literature on the stratigraphy of the area, but in the discussion of individual units, we cite the most pertinent references, to which the reader may refer for additional information.

Acknowledgments.-We thank D.M. Cheney, P.L. FitzMaurice, G.T. Cebula, and Ezekiel Rivera for their care in separating the minerals dated in this study. We are grateful to J.H. Mackin, P.L. Williams, D.S. Barker, M.G. Best, H.R. Blank, Florian Maldonado, A.L. Deino, R.B. Scott, M.E. MacLachlan, C.S. Grommé, and L.F. Hintze for many comments over many years that helped formulate concepts given in this report. Significant improvements to the manuscript were kindly provided by K.S. Kellogg, J.M. O’Neill, Florian Maldonado, M.G. Best, W.A. Bryant, and L.M. Carter.

\section{GEOLOGIC SETTING}

Cenozoic rocks of the Marysvale volcanic field can be divided into three main sequences: (1) lower Cenozoic (Paleocene through Oligocene) fluvial-lacustrine sedimentary rocks that overlie Paleozoic and Mesozoic rocks in angular unconformity; (2) thick, middle Cenozoic (Oligocene and lower Miocene, 34 ? to $22 \mathrm{Ma}$ ), intermediate-composition, generally calc-alkaline volcanic rocks deposited mostly from

Figure 2 (facing page). Composite stratigraphic column of Cenozoic rocks in and near the Marysvale volcanic field. Numbers refer to isotopic ages of volcanic rocks rounded to the nearest half million years. Boundaries of the three stratigraphic sequences shown by heavy lines. Most rock units intertongue with units shown to their left or right; units that are restricted in age (thin boxes) are shown within the unit with which they intertongue the most, but many of the units shown by thin boxes intertongue with other units farther left or right. See text for discussion of "related units" that cannot be adequately shown in the figure. The age of the Brian Head-Claron boundary is poorly known and is shown by a queried line. For emphasis, patterns shown for Mount Belknap Volcanics, Mount Dutton Formation, and Bullion Canyon Volcanics. 


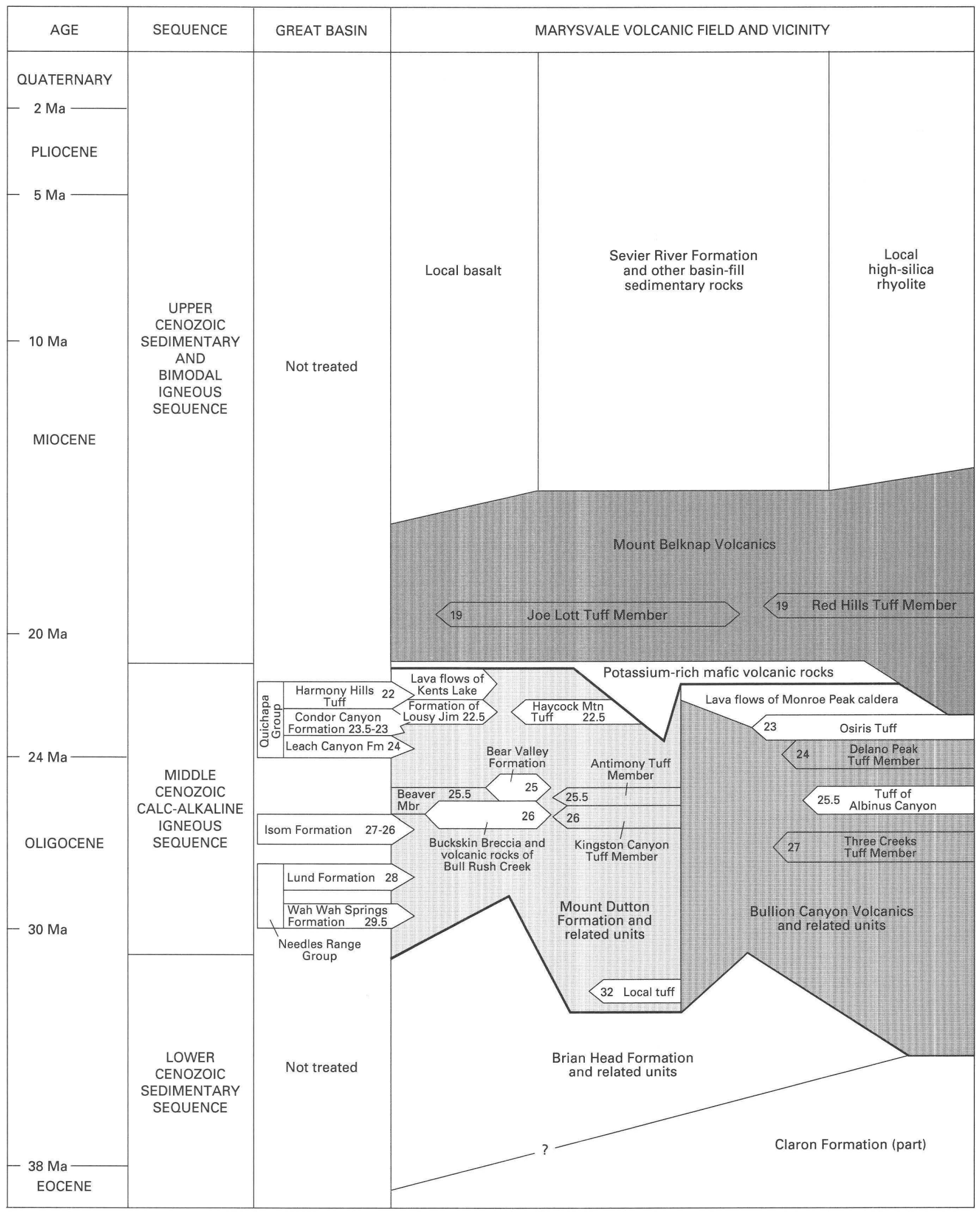


stratovolcanoes and calderas, and related source intrusions; and (3) upper Cenozoic (23 Ma to Quaternary), compositionally bimodal (basalt and high-silica rhyolite) volcanic rocks, deposited from varied rhyolite sources such as calderas and volcanic domes and from basalt sources such as cinder cones and shield volcanoes, local source intrusions associated with these bimodal rocks, and overlying and intertongued clastic basin-fill sedimentary rocks (fig. 2).

The basal, mostly prevolcanic sedimentary sequence consists in large part of the Claron Formation in and near the Marysvale field; the age of this formation is poorly constrained but probably is late Paleocene through Oligocene. The overlying volcanic rocks in the field have a volume of at least $12,000 \mathrm{~km}^{3}$, of which about 95 percent is generally calc-alkaline and 5 percent is part of a bimodal assemblage (basalt and high-silica rhyolite) (Rowley and others, report in progress). More than 90 percent of the volume of Marysvale volcanic rocks consists of lava flows, volcanic mudflow breccia, and flow breccia, and less than 10 percent consists of tuff (Rowley and others, report in progress). Calc-alkaline magmatism began in the field by at least $32 \mathrm{Ma}$, and probably earlier (34 Ma?), and continued until about $21 \mathrm{Ma}$. Most bimodal magmatism took place between $23 \mathrm{Ma}$ and $16 \mathrm{Ma}$, but some small rhyolitic and basalt centers erupted after this, to as recently as the Quaternary. Basin-fill sedimentation in the northern Tushar Mountains began between 19 and $14 \mathrm{Ma}$ and continues today.

The majority of the magmatism in the Marysvale volcanic field took place in middle Cenozoic (Oligocene and Miocene) time, and resulted in intermediate-composition, calc-alkaline lava flows, flow breccia, volcanic mudflow breccia, and tuff derived from central volcanoes and calderas clustered near Marysvale, Utah. The sequence corresponds to the voluminous calc-alkaline magmatism common throughout the western United States that probably formed during subduction beneath the western United States. (See for example Lipman and others, 1972; Lipman, 1992.) Most volcanic edifices were small to large stratovolcanoes, but shield volcanoes and volcanic domes also were common. Near Marysvale, especially in the northern and central Tushar Mountains and northern Sevier Plateau, most rocks are dacite and andesite that contain abundant phenocrysts. Most of these relatively highly evolved rocks were called the Bullion Canyon Volcanics, a name first used by Callaghan (1939). This thick sequence was deposited between 34 ? and $22 \mathrm{Ma}$ (Steven and others, 1979) from vents centered in the Tushar Mountains (fig. 3). Volcanic rocks from centers on the north (southern Pavant Range) that intertongue with the lower part of the Bullion Canyon Volcanics include the informally named volcanic rocks of Dog Valley, the overlying volcanic rocks of Wales Canyon, and an unnamed dome (Cunningham and others, 1983). Other volcanic rocks that intertongue on the northeast (Pavant Range) and east (Sevier Plateau) with rocks of the Bullion Canyon Volcanics include, from north to south (Cunningham and others, 1983),
(1) the volcanic rocks of Signal Peak, an andesitic shield volcano sequence in the northern Sevier Plateau and southern Pavant Range; (2) the volcanic rocks of Little Table, an andesitic shield volcano sequence in the central Sevier Plateau; (3) the volcanic rocks of Willow Spring, a dacitic stratovolcano sequence in the central Sevier Plateau; and (4) the volcanic rocks of Langdon Mountain, a dacitic stratovolcano sequence in the central Sevier Plateau. These units are more extensive east of the areas we have mapped (Williams and Hackman, 1971; Mattox, 1991a, 1992). The units are not specifically shown in figure 2 .

Shallow consanguineous intrusions of monzonite and quartz monzonite were emplaced into the flanks and cores of the major volcanoes of the Bullion Canyon Volcanics and other units late during volcano evolution. Failure of roof rocks above some of these shallow intrusions resulted in eruption of ash-flow tuff units, which covered much of the field and beyond, and in subsidence of source areas to form calderas (Steven, Rowley, and Cunningham, 1984). The Three Creeks Tuff Member and the Delano Peak Tuff Member of the Bullion Canyon Volcanics came from the Three Creeks caldera in the southern Pavant Range and the Big John caldera in the southern Tushar Mountains, respectively. Most Bullion Canyon volcanism terminated with eruptions of the Osiris Tuff at about $23 \mathrm{Ma}$ from the northern Sevier Plateau; the source area subsided as the Monroe Peak caldera, which occupies an area in the Marysvale and northern Sevier Plateau area. Hydrothermally altered rocks and mineral deposits of base and precious metals (mostly of chalcophile elements) formed during Bullion Canyon magmatism in the Tushar Mountains and Sevier Valley.

In contrast to the shallow, more evolved rocks in the center of the Marysvale field, the stratovolcano rocks in the southern part of the field are more mafic (andesite and subordinate dacite) and most contain small sparse phenocrysts. These belong to the Mount Dutton Formation (Anderson and Rowley, 1975), a thick sequence of volcanic mudflow breccia, lava flows, and flow breccia that formed from about 34 to $21 \mathrm{Ma}$ and intertongued on the north with Bullion Canyon Volcanics and the products of other volcanoes (Fleck and others, 1975). The Mount Dutton is derived from numerous centers that are aligned roughly east-west through the northern Markagunt Plateau, southern Tushar Mountains, and

Figure 3 (facing page). Generalized geologic map of the Marysvale volcanic field and vicinity, Utah, showing locality of samples whose ages and analytical data are reported here. Sample numbers are those given in tables 1, 2, and 3. A, Annabella; B, Beaver; BC, Bryce Canyon National Park; BH, Brian Head; C, Cedar City; CB, Cedar Breaks National Monument; Ci, Circleville; E, Elsinore; F, Fillmore; H, Hatch; J, Joseph; Ju, Junction; K, Kingston Canyon; M, Marysvale, Mi, Milford; Mv, Minersville; P, Panguitch; Pa, Parowan; R, Richfield; S, Salina; Se, Sevier; Sp, Spry. Hachures show the following calderas: BJ, Big John caldera; MB, Mount Belknap caldera; MP, Monroe Peak caldera; TC, Three Creeks caldera. 


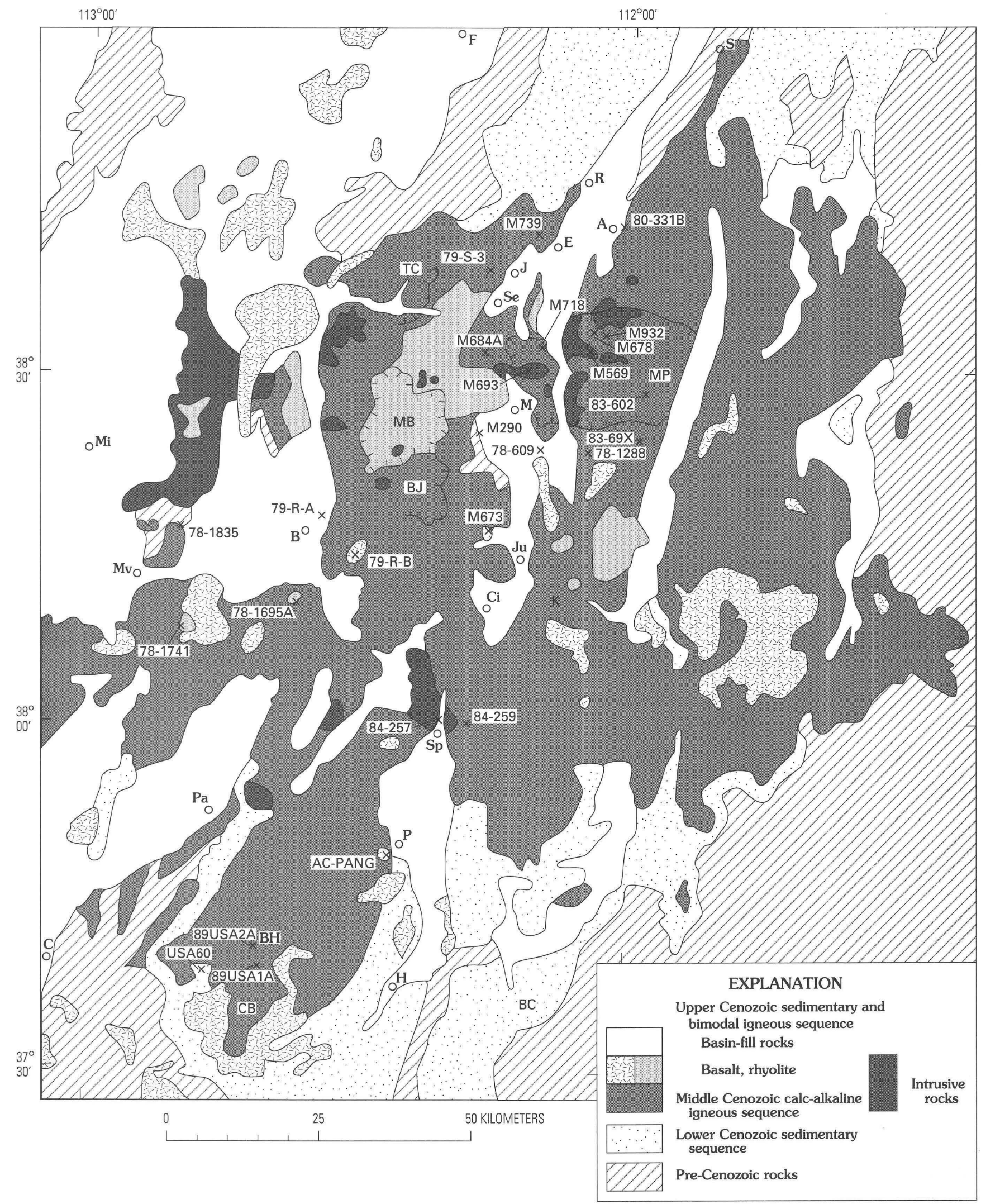


southern Sevier Plateau. These centers occur along a broad, long-lived, east-striking fault zone named the Blue Ribbon lineament, which extends westward into Nevada (Rowley, Lipman, and others, 1978; Bartley and others, 1992) and is one of numerous lineaments in the Great Basin and transition zone (Ekren and others, 1976; Rowley and others, report in progress). Mount Dutton source intrusions are rarely exposed, probably because phenocryst-poor Mount Dutton rocks were erupted from deep magma chambers. As a consequence, hydrothermally altered surface rocks and mineral deposits are sparse in areas underlain by the Mount Dutton Formation. The Mount Dutton Formation also contains several tuff members whose eruptive sources probably were in the northern Marysvale field.

Shallow, calc-alkaline laccoliths unrelated to Mount Dutton magmatism were emplaced into lower parts of the Claron Formation in the northern Markagunt Plateau south of the Mount Dutton sources. The largest of these laccoliths is the Spry intrusion (Anderson and Rowley, 1975), which erupted to form a dacitic vent complex, lava flows, and tuffs (Anderson, Rowley, Blackman, and others, 1990). Borrowing on an idea of H.R. Blank (oral commun., 1991) and developed in greater detail by Nickelsen and Merle (1991), Merle and others (1993), Anderson (1993), and Maldonado (in press), we conclude that this and other laccoliths in the area were fed from a batholith complex that underlies the southern flank of the Marysvale volcanic field (Rowley and others, report in progress). This batholith complex is part of the Delamar-Iron Springs igneous belt, which is south of and parallel to the Pioche-Marysvale igneous belt, and it may extend westward to laccoliths of the "Iron Axis" (Blank and others, 1992).

The middle Cenozoic calc-alkaline volcanic rocks of the Marysvale volcanic field are overlain by upper Cenozoic bimodal (basalt and high-silica rhyolite) volcanic rocks. The changeover from calc-alkaline to bimodal magmatism was abrupt in places and marks a dramatic change in petrologic regime, as in other parts of the western United States (Christiansen and Lipman, 1972), as subduction along the west side of North America waned. For example, in the western part of the Monroe Peak caldera, latest calcalkaline intracaldera lava flows that mark the termination of caldera activity were deposited at $22-21 \mathrm{Ma}$, the same time as nearby high-silica rhyolite volcanic domes of the bimodal sequence were being extruded. In general, the first products of bimodal magmatism in the Marysvale field consist of potassium-rich mafic volcanic rocks from local centers (Best and others, 1980). Some of these have been named, such as the mafic lava flows of Birch Creek Mountain (22.5 Ma) and the mafic lava flows of Circleville Mountain (23 Ma) (Anderson and Rowley, 1975; Anderson, Rowley, Blackman, and others, 1990). Other smaller centers of similar-age potassium-rich mafic volcanic rocks have been mapped elsewhere in the Marysvale field (Steven and others, 1990).
The oldest bimodal rocks, defined by Callaghan (1939) as the Mount Belknap Volcanics, were deposited in part within but mostly west of the Monroe Peak caldera between 22 and $14 \mathrm{Ma}$ (Cunningham and Steven, 1979a). Mount Belknap Volcanics consist mostly of high-silica rhyolitic ash-flow tuff, lava flows, flow breccia, and intrusions exposed in the central and northern Tushar Mountains and Antelope Range. The tuff units and most flows are derived from two main sources, an eastern source area mostly in the Antelope Range that includes the small Red Hills caldera, and a western source area in the central Tushar Mountains that includes the large Mount Belknap caldera and its main ash-flow tuff, the Joe Lott Tuff Member (19 Ma) of the Mount Belknap Volcanics (Steven, Rowley, and Cunningham, 1984; Budding and others, 1987). Hydrothermally altered rocks, including vein alunite deposits, and lithophileelement mineral deposits such as uranium and molybdenum formed during Mount Belknap volcanic activity.

Small high-silica rhyolite domes and related lava flows of the bimodal suite, as young as Pleistocene, are scattered throughout the volcanic field. Basalt lava flows derived from small local cones, as young as Pleistocene, are also widely scattered in and near the Marysvale field.

The Marysvale field, which is mostly in the Colorado Plateau-Great Basin transition zone (fig. 1), is broken by numerous high-angle normal faults of several middle Tertiary to Quaternary episodes of east-west extension (Rowley and others, report in progress). The faults of the oldest of these episodes of extensional deformation, which formed during emplacement of fundamentally calc-alkaline rocks, are not well known because they have been covered by younger volcanic rocks and have been deformed by later faults. Some faults of this older episode bound a series of west-northwest-striking horsts and grabens in the northern Markagunt Plateau, perhaps related to the Blue Ribbon lineament, that are well constrained at about 27-25 Ma (J.J. Anderson, 1971, 1985, 1988). Older faults also include those formed above calc-alkaline batholiths (Steven, 1988). The change to bimodal magmatism at about $22 \mathrm{Ma}$ was coeval with a regional increase in east-west extension; faults of the interval from 22 to $10 \mathrm{Ma}$, however, are poorly known, in part because of a lack of regional stratigraphic units of this age. Certainly basins started to form, perhaps largely by warping, soon after $22 \mathrm{Ma}$, and basin-fill sediments derived from erosion of upwarped areas started to be deposited then; these sediments make up the lower part of the Sevier River Formation (Callaghan, 1938; Steven and others, 1979). The main extensional deformation in the Marysvale field probably took place later, during the basin-range episode, which began at about $10 \mathrm{Ma}$ and created the present fault-block topography. The age of most deformation of this episode is constrained by relationships in the Kingston Canyon area of the southern Sevier Plateau (see section, "Small Rhyolite Volcanic Centers") at between 8 and $5 \mathrm{Ma}$ (Rowley and others, 1981), with lesser offset continuing into the Pliocene and 
Quaternary. Most faults are normal faults, but strike-slip zones occur locally as accommodation zones or in areas where the maximum principal stress axis changed locally from vertical to horizontal and oriented north-south (Anderson and Barnhard, 1992). Grabens formed during basinrange faulting, and basin-fill sedimentary rocks of the upper part of the Sevier River Formation (Steven and others, 1979; Anderson, 1987) were deposited in these basins.

\section{LOWER CENOZOIC SEDIMENTARY SEQUENCE}

\section{CLARON FORMATION AND RELATED UNITS}

The oldest Tertiary unit in the Marysvale volcanic field is a sequence of fluvial and lacustrine sedimentary rocks that we have mapped as the Claron Formation (Anderson and Rowley, 1975), after correlating them with rocks in the Iron Springs mining district (for example, Mackin, 1947, 1960; Mackin and Rowley, 1976). The lower "red" Claron, as much as about $400 \mathrm{~m}$ of red and orange limestone, shale, sandstone, and conglomerate, is spectacularly exposed as the beautiful hoodoos in Bryce Canyon National Park and Cedar Breaks National Monument south of the Marysvale field (fig. 1). The rocks record erosion of highlands formed during Laramide deformation and deposition in the basin that may have started to form in the west and south and transgressed north and northeast (Goldstrand, 1990, 1992). These rocks are overlain by a sequence that we previously mapped as "white" Claron (Anderson and Rowley, 1975), also as much as about $400 \mathrm{~m}$ thick, of white and light-gray limestone succeeded upward by mostly gray tuffaceous sandstone, claystone, conglomerate, and minor white limestone and chalcedony. In places, some beds in the "white" sequence are unconformable on the "red" Claron. In the heart of the Marysvale field, the Claron is thin or missing, suggesting either that the area was a topographic high and few sediments were deposited or that uplift that preceded deposition of the volcanic rocks led to erosion of Claron rocks (Anderson and Rowley, 1975).

We have not studied the Claron Formation in detail. With additional work, the rocks now lumped as the Claron could probably be partly or completely reassigned as other formations and members, as was done locally for the lower Claron by Bowers (1972) in Table Cliff Plateau southeast of the Marysvale volcanic field (fig. 1), Bowers (1990) in the Bryce Canyon Park area, and Anderson and Kurlich (1989) and Kurlich and Anderson (1991, in press) in the Hatch area of the southeastern Markagunt Plateau (fig. 1). In a regional study of southwest Utah, Goldstrand $(1990,1992)$ studied and extended Bowers' units and proposed a new unit, all of rocks that we formerly may have mapped as the lower part of the red Claron. In addition, mapping and stratigraphic studies in progress by E.G. Sable, J.J. Anderson, Florian Maldonado, and others in the Brian Head area of the southwestern Markagunt Plateau (fig. 1) indicate that the upper white part of the sequence that here we previously called the Claron is better broken into the Claron (the lower white and light-gray limestone, about $60 \mathrm{~m}$ thick) and an overlying clastic unit (about $300 \mathrm{~m}$ near Brian Head). The overlying clastic unit was mapped in the Red Hills west of the Markagunt Plateau (fig. 1) as the sedimentary and volcanic rocks of the Red Hills (Maldonado and Williams, 1993a, b; Maldonado and others, 1992). Based on later work in the Brian Head area, this clastic sequence now is identified as the Brian Head Formation (restricted) by Maldonado and Moore (1993), Anderson (1993), and Maldonado (in press). Presently Claron rocks are the subject of a major study on their continental depositional environments and overall origin (Mullett and others, 1988a, b; Mullett, 1989). Preliminary results of this study indicate that the original strata in the formation were modified and extensively bioturbated during development of B soil horizons that formed after deposition.

The age of the Claron is poorly constrained, and because of the incidence of rare invertebrate fossils (Gregory, 1951) that suggested that lower parts are Eocene, we previously considered the formation to be Eocene and Oligocene (Anderson and Rowley, 1975). Goldstrand (1990), however, noted that palynomorph fossils in samples from basal Claron rocks from the eastern Pine Valley Mountains indicate a late Paleocene age for these rocks, whereas a fission-track date of $50 \pm 6 \mathrm{Ma}$ that he determined from rocks collected just below the Claron contact in the Table Cliff Plateau indicates that there the basal Claron is Eocene. He also found gastropod fossils in the lower part of the Claron that resemble those collected from the Paleocene to Eocene Flagstaff Formation of central Utah by LaRocque (1960). Thus we agree with Goldstrand $(1990,1992)$ that, as currently used, the Claron Formation ranges from late Paleocene to Oligocene. The current stratigraphic studies of the Brian Head Formation, however, may restrict the upper age of the Claron, and the long overall age range of the Claron suggests its further future subdivision.

Regionally, the age of the upper parts of the Claron and Brian Head Formations is constrained by a widespread ash-flow tuff that commonly overlies them, the Oligocene Wah Wah Springs Formation of the Needles Range Group (see p. 13), whose K-Ar ages average $29.5 \mathrm{Ma}$ (Best, Christiansen, and Blank, 1989) and whose unpublished ${ }^{40} \mathrm{Ar} /{ }^{39} \mathrm{Ar}$ ages are somewhat older than $29.5 \mathrm{Ma}$ (M.G. Best, written commun., 1993). In the southeastern Bull Valley Mountains (fig. 1), tuff beds of the Wah Wah Springs Formation and overlying Isom Formation (described in section, "Intertongued Great Basin Ash-flow Sheets") occur interbedded within limestone near the top of basal Tertiary units that may correlate with either the Claron Formation or the Brian Head Formation (Blank, 1959; Wiley, 1963; Hintze, 1986; Anderson and Hintze, 1993). Similarly, 
Wah Wah Springs Formation in the top part of the Brian Head Formation just east-southeast of Brian Head received four new $\mathrm{K}$-Ar dates (see table 1).

In an effort to better constrain the age of the upper part of the Claron and the age of the Brian Head Formation, we dated tuffs in the units. Schneider (1967) reported "mica zones" in the red Claron rocks at Cedar Breaks National Monument but, despite a careful search, we were unable to find any such beds. In the northern Markagunt Plateau and southern Sevier Plateau (Anderson, Rowley, Machette, and others, 1990), a local, densely welded, crystal-poor ash-flow tuff (sample R-4 of Fleck and others, 1975) in beds apparently equivalent to the Brian Head Formation has a K-Ar date on biotite of $31.9 \pm 0.5 \mathrm{Ma}$ (Fleck and others, 1975; Anderson and Kurlich, 1989). Maldonado (in press) reported a K-Ar date of about $34 \mathrm{Ma}$ from an ash-flow tuff bed in the Brian Head Formation from the Red Hills. Probably some of the airfall and ash-flow tuffs in the Claron and Brian Head Formations represent early eruptions from the Marysvale volcanic field.
Table 1. Data for potassium-argon dates, Marysvale volcanic field and adjacent areas, Utah.

\begin{tabular}{|c|c|c|c|c|}
\hline $\begin{array}{l}\text { Rock unit, sample No. } \\
\text { (fig. 3); mineral analyzed }\end{array}$ & $\begin{array}{c}{ }^{2} \mathrm{~K}_{2} \mathrm{O} \\
\text { (percent) }\end{array}$ & $\begin{array}{l}{ }^{* 40} \mathrm{Ar}\left(10^{-10}\right. \\
\text { moles/gram })\end{array}$ & $\begin{array}{l}{ }^{*} 40 \mathrm{Ar} \\
\text { (percent) }\end{array}$ & $\begin{array}{l}\text { Age in } \\
\text { m.y. } \pm 2 \sigma\end{array}$ \\
\hline \multicolumn{5}{|l|}{ Sevier River Formation } \\
\hline 80-331B; S & $5.62,5.58$ & 0.448 & 34.1 & $5.6 \pm 0.4$ \\
\hline $78-609 ; \mathrm{S}$ & $3.48,3.48$ & 0.684 & 39.2 & $13.6 \pm 0.8$ \\
\hline \multicolumn{5}{|l|}{ Rhyolite of Teddys Valley } \\
\hline $78-1741 ; W$ & $5.01,4.96$ & 0.570 & 31.6 & $7.9 \pm 0.5$ \\
\hline \multicolumn{5}{|l|}{ Rhyolite of Beaver airport } \\
\hline $78-1695 \mathrm{~A} ; \mathrm{W}$ & $5.13,5.09$ & 0.615 & 83.5 & $8.3 \pm 0.3$ \\
\hline \multicolumn{5}{|l|}{ Basalt } \\
\hline M673; W & $2.76,2.80$ & 0.436 & 55.5 & $10.9 \pm 0.4$ \\
\hline AC-PANG; W & $1.60,1.62$ & 0.1231 & 21.8 & $5.3 \pm 0.5$ \\
\hline \multicolumn{5}{|l|}{ Basaltic andesite } \\
\hline $79-S-3 ; W$ & $2.51,2.61$ & 0.912 & 70.3 & $21.6 \pm 1.0$ \\
\hline \multicolumn{5}{|l|}{$\begin{array}{l}\text { Potassium-rich mafic volcanic } \\
\text { rocks }\end{array}$} \\
\hline 79-R-A; W & $3.74,3.79$ & 1.182 & 78.4 & $21.7 \pm 0.8$ \\
\hline 79-R-B. W & $3.72,3.80$ & 1.201 & 76.4 & $22.1 \pm 0.8$ \\
\hline \multicolumn{5}{|l|}{ Mineral Mountains batholith } \\
\hline $78-1835 ; S$ & $7.75,7.72$ & 2.496 & 78.3 & $22.3 \pm 0.8$ \\
\hline $78-1835 ; \mathrm{B}$ & $8.33,8.34$ & 2.719 & 70.3 & $22.5 \pm 0.9$ \\
\hline \multicolumn{5}{|l|}{$\begin{array}{l}\text { Lava flows, Monroe Peak } \\
\text { caldera }\end{array}$} \\
\hline M678; S & $6.05,6.45$ & 1.835 & 45.2 & $20.3 \pm 0.8$ \\
\hline M678; B & $8.38,8.39$ & 2.649 & 78.5 & $21.8 \pm 0.8$ \\
\hline M718; S & $7.88,8.17$ & 2.480 & 87.4 & $21.3 \pm 0.7$ \\
\hline $83-602 ; S$ & $8.69,8.70$ & 2.803 & 70.0 & $22.3 \pm 0.8$ \\
\hline $83-602 ; \mathrm{B}$ & $7.19,7.34$ & 2.377 & 67.0 & $22.6 \pm 1.0$ \\
\hline \multicolumn{5}{|l|}{ Haycock Mountain Tuff } \\
\hline 89USA2A; P & $1.002,0.995$ & 0.218 & 58.7 & $22.3 \pm 1.1$ \\
\hline 89USA1A; B & $7.54,7.64$ & 2.627 & 48.6 & $22.8 \pm 1.1$ \\
\hline 89USAlA; S & $11.54,11.27$ & 0.323 & 91.8 & $24.8 \pm 1.0$ \\
\hline \multicolumn{5}{|l|}{ Pluton, Monroe Peak caldera } \\
\hline M932; A & $6.81,6.95$ & 2.293 & 40.8 & $23.2 \pm 1.2$ \\
\hline \multicolumn{5}{|l|}{ Antimony Tuff Member } \\
\hline $78-1288 ; \mathrm{S}$ & $8.47,8.49$ & 3.127 & 89.9 & $25.4 \pm 0.9$ \\
\hline \multicolumn{5}{|l|}{ Tuff of Albinus Canyon } \\
\hline M739; P & $0.73,0.75$ & 0.273 & 71.2 & $25.3 \pm 1.3$ \\
\hline \multicolumn{5}{|l|}{ Spry intrusion } \\
\hline $84-257 ; P$ & $0.59,0.58$ & 0.2214 & 57.9 & $26.1 \pm 1.8$ \\
\hline \multicolumn{5}{|l|}{$\begin{array}{l}\text { Volcanic rocks of Bull Rush } \\
\text { Creek }\end{array}$} \\
\hline $84-259 ; \mathrm{P}$ & $0.47,0.48$ & 0.1820 & 18.7 & $26.4 \pm 3.2$ \\
\hline $84-259 ; \mathrm{H}$ & $0.65,0.65$ & 0.2771 & 40.3 & $29.4 \pm 2.2$ \\
\hline \multicolumn{5}{|l|}{ Wah Wah Springs Formation } \\
\hline USA60A; B & $5.76,6.25$ & 2.6557 & 58.2 & $30.4 \pm 3.1$ \\
\hline USA60A; H & $0.95,0.94$ & 0.4172 & 68.8 & $30.4 \pm 1.1$ \\
\hline USA60B; B & $5.93,5.57$ & 2.7101 & 54.1 & $32.4 \pm 3.4$ \\
\hline USA60B; H & $0.83,0.84$ & 0.3564 & 85.9 & $29.1 \pm 1.0$ \\
\hline
\end{tabular}

${ }^{1}$ Constants: ${ }^{40} \mathrm{~K} \lambda_{\varepsilon}=0.581 \times 10^{-10} \mathrm{yr}^{-1}, \lambda_{\beta}=4.962 \times 10^{-10} \mathrm{yr}^{-1},{ }^{40} \mathrm{~K} / \mathrm{K}=1.67 \times 10^{-4}$; mineral analyzed: $A$, alunite; $B$, biotite; $H$, hornblende; $P$, plagioclase; $S$, sanidine; $\mathrm{W}$, whole rock

${ }^{2}$ Determined by flame photometer.

\section{SAMPLE DESCRIPTIONS}

80-331B. Airfall tuff from upper part of Sevier River Formation, from $3.9 \mathrm{~km}$ east of Annabella; lat $38^{\circ} 42^{\prime} 38^{\prime \prime} \mathrm{N}$., long $112^{\circ} 00^{\prime} 42^{\prime \prime} \mathrm{W}$.

78-609. Airfall tuff from Sevier River Formation, from $11 \mathrm{~km}$ south-southeast of Marysvale; lat $38^{\circ} 21^{\prime} 45^{\prime \prime} \mathrm{N}$., long $112^{\circ} 10^{\prime} 35^{\prime \prime} \mathrm{W}$.

78-1741. Apache tears from rhyolite lava flow of the rhyolite of Teddys Valley, from about $17 \mathrm{~km}$ south-southwest of Beaver (shown by Anderson, Rowley, Machette, and others, 1990); lat $38^{\circ} 08^{\prime} 55^{\prime \prime}$ N., long $112^{\circ} 43^{\prime} 25^{\prime \prime}$ W. Preliminary data published by Anderson, Rowley, Machette, and others, 1990.

78-1695A. Apache tears from rhyolite lava flow of the rhyolite of Beaver airport, from about $10 \mathrm{~km}$ south-southwest of Beaver (shown by Anderson, Rowley, Machette, and others, 1990): lat $38^{\circ} 11^{\prime} 40^{\prime \prime}$ N., long $112^{\circ} 41^{\prime} 10^{\prime \prime} \mathrm{W}$. Preliminary data first published by Anderson, Rowley, Machette, and others, 1990.

M673. Basalt lava flow from ridge just north of City Creek, west of Junction; lat $38^{\circ} 16^{\prime} 12^{\prime \prime} \mathrm{N}$., long $112^{\circ} 16^{\prime} 22^{\prime \prime} \mathrm{W}$.

AC-PANG. Basalt lava flow from $1.5 \mathrm{~km}$ south-southeast of Panguitch; lat $47^{\circ} 48^{\prime} \mathrm{N}$., long $112^{\circ} 25^{\prime} 45^{\prime \prime} \mathrm{W}$.

79-S-3. Basaltic andesite lava flow that overlies tuff of Albinus Canyon, from Dry Gulch, west of Joseph; lat $38^{\circ} 37^{\prime} 40^{\prime \prime}$ N., long $112^{\circ} 15^{\prime} 30^{\prime \prime} \mathrm{W}$.

79-R-A. Lava flow in fault block poking through basin-fill sediments, from $1.5 \mathrm{~km}$ east-northeast of the racetrack east of Beaver; lat $38^{\circ} 17^{\prime} 10^{\prime \prime} \mathrm{N}$., long $112^{\circ} 35^{\prime} 20^{\prime \prime} \mathrm{W}$.

79-R-B. Lava flow capping Black Mountain, from $3 \mathrm{~km}$ southeast of the racetrack east of Beaver; lat $38^{\circ} 15^{\prime} 50^{\prime \prime}$ N., long $112^{\circ} 34^{\prime} 30^{\prime \prime} \mathrm{W}$.

78-1835. Glassy margin of a hypabyssal plug in southern Mineral Mountains; lat $38^{\circ} 14^{\prime} 50^{\prime \prime} \mathrm{N}$., long $112^{\circ} 51^{\prime} 20^{\prime \prime} \mathrm{W}$.

M678. Lava flows of Monroe Peak, within Monroe Peak caldera, from roadcut $0.35 \mathrm{~km}$ northeast of Hunts Lake and $16.5 \mathrm{~km}$ northeast of Marysvale; lat $38^{\circ} 32^{\prime} 54^{\prime \prime} \mathrm{N}$., long $112^{\circ} 05^{\prime} \mathrm{W}$

M718. Lava flows of Monroe Peak, within Monroe Peak caldera, from $9.6 \mathrm{~km}$ southsoutheast of Joseph (shown by Rowley and others, 1988b); lat $38^{\circ} 32^{\prime} 30^{\prime \prime} \mathrm{N}$., long $112^{\circ} 10^{\prime} 40^{\prime \prime} \mathrm{W}$. Preliminary data published by Rowley and others (1988b). See also fission-track date of this sample in table 2.

83-602. Lava flows from volcanic dome of Lower Box Creek Reservoir, within Monroe Peak caldera; lat $38^{\circ} 28^{\prime} 15^{\prime \prime} \mathrm{N}$., long $111^{\circ} 58^{\prime} \mathrm{W}$.

89USA2A. Basal vitrophyre of Haycock Mountain Tuff from the southwest side of the top of Haycock Mountain; lat $37^{\circ} 43^{\prime} 03^{\prime \prime}$ N., long $112^{\circ} 34^{\prime} 50^{\prime \prime} \mathrm{W}$.

89USA1A. Haycock Mountain Tuff from Bunker Creek: $0.2 \mathrm{~km}$ north of dirt road and $3.4 \mathrm{~km}$ west-southwest of Panguitch Lake, lat $37^{\circ} 42^{\prime} 01^{\prime \prime} \mathrm{N}$., long $112^{\circ} 41^{\prime} 40^{\prime \prime} \mathrm{W}$.

M932. Replacement alunite due to emplacement of intracaldera pluton of Monroe Peak caldera, from summit of Monroe Peak; lat $38^{\circ} 28^{\prime} 42^{\prime \prime} \mathrm{N}$., long $112^{\circ} 06^{\prime} 16^{\prime \prime} \mathrm{W}$.

78-1288. Basal vitrophyre of Antimony Tuff Member of Mount Dutton Formation, from $22 \mathrm{~km}$ southeast of Marysvale; lat $38^{\circ} 20^{\prime} 45^{\prime \prime} \mathrm{N}$., long $112^{\circ} 04^{\prime} 35^{\prime \prime} \mathrm{W}$.

M739. Ash-flow tuff collected in Albinus Canyon, from $3 \mathrm{~km}$ west-northwest of Elsinore; lat $38^{\circ} 41^{\prime} 46^{\prime \prime} \mathrm{N}$., long $112^{\circ} 11^{\prime} 30^{\prime \prime} \mathrm{W}$.

84-257. Intrusive rock from roadcut along U.S. Highway 89 about $17 \mathrm{~km}$ south-southwest of Circleville (shown by Anderson, Rowley, Blackman, and others, 1990); lat $38^{\circ} 02^{\prime} 10^{\prime \prime} \mathrm{N}$., long $112^{\circ} 21^{\prime} 20^{\prime \prime} \mathrm{W}$. Preliminary data published by Anderson, Rowley, Blackman, and others, 1990.

84-259. Dike of the volcanic rocks of Bull Rush Creek, from about $16.5 \mathrm{~km}$ southsouthwest of Circleville (shown by Anderson, Rowley, Blackman, and others, 1990 ); lat $38^{\circ} 01^{\prime} 55^{\prime \prime}$ N., long $112^{\circ} 19^{\prime} 25^{\prime \prime}$ W. Preliminary data published by Anderson, Rowley, Blackman, and others, 1990.

USA60. Ash-flow tuff about $3 \mathrm{~m}$ thick and located $3 \mathrm{~m}$ below Isom Formation (sample USA60A is from higher in the bed than B) in Brian Head Formation from Lowder Creek, from $3.7 \mathrm{~km}$ east-southeast of Brian Head; lat $37^{\circ} 40^{\prime} 52^{\prime \prime} \mathrm{N}$., long $112^{\circ} 47^{\prime} 48^{\prime \prime} \mathrm{W}$. 


\section{MIDDLE CENOZOIC CALC-ALKALINE IGNEOUS SEQUENCE}

\section{BULLION CANYON VOLCANICS}

The Oligocene and Miocene Bullion Canyon Volcanics (Callaghan, 1939; Steven and others, 1979) is a complex assemblage of stratovolcano rocks in the central and northern parts of the Marysvale volcanic field. The rocks range in composition from andesite to low-silica rhyolite, but most are dacitic and commonly contain abundant phenocrysts of mostly plagioclase and subordinate amounts of biotite, hornblende, and pyroxene. These relatively highly evolved rocks were derived from shallow source cupolas of an underlying batholith; numerous intrusions are currently exposed, emplaced into Bullion Canyon and other volcanic units. Using terminology adapted from Parsons $(1965,1969)$ and Smedes and Prostka (1973), Anderson and Rowley (1975) applied "vent facies" to rocks deposited in and near sources made up of clustered stratovolcanoes and "alluvial facies" for more distal flank asemblages. Vent-facies rocks consist mainly of lava flows, autoclastic flow breccia, and volcanic mudflow breccia that were deposited on the slope of a volcanic edifice (stratovolcano), whereas alluvial facies rocks consist of volcanic mudflow breccia, conglomerate, and sandstone deposited farther away on the edifice and in valleys draining the edifice. The Bullion Canyon Volcanics fits these criteria, although intertonguing vent facies and alluvial facies were not separated during mapping. Bullion Canyon vent-facies rocks are concentrated in the area between the central Tushar Mountains and the western Sevier Plateau; alluvial-facies rocks occur in other parts of the Tushar Mountains as well as in the southern Pavant Range and northern Sevier Plateau. The thickness of the formation is probably at least $1,500 \mathrm{~m}$, although no complete sections are known in the heart of the vent complex, where deposits are thickest. Basal parts of the Bullion Canyon Volcanics underlie the >29.5-Ma Wah Wah Springs Formation. A clast from a bed of apparent volcanic mudflow breccia near the base of the unit in the southwestern Tushar Mountains was dated directly using fission-track methods on zircon at $29.9 \pm 2.6$ Ma (Kowallis and Best, 1990); the bed underlies the 27-Ma Three Creeks Tuff Member (fig. 2; see paragraph following), but its stratigraphic relationship to the Wah Wah Springs Formation is unknown. Airfall and waterlaid tuff near Salina that is believed to have been derived from the Marysvale volcanic field was dated by $\mathrm{K}-\mathrm{Ar}$ methods at $34.2 \mathrm{Ma}$ by Willis (1985). Along with the tuffs in the Brian Head Formation, this is the oldest volcanic activity yet reported in the Marysvale field, and it may represent early eruptions of the Bullion Canyon Volcanics.

Subdivision of the Bullion Canyon Volcanics is partly based upon mapping distinctive ash-flow tuff members in the unit. One of these is a thick, crystal-rich, ash-flow sheet that earlier (for example, Rowley, 1968) was correlated with one of the ash-flow tuffs of the Needles Range Group (see section, "Intertongued Great Basin Ash-flow Sheets"). Best and others (1973), during a regional stratigraphic study of Needles Range tuffs, traced the same unit over large parts of the Great Basin and proposed for it the name Wallaces Peak Tuff Member of the Needles Range Formation (later raised to group rank; fig. 2); they interpreted it to be the youngest Needles Range unit. Later mapping in the Marysvale field showed that the unit was derived from the Marysvale field, and Steven and others (1979) defined it as the Three Creeks Tuff Member of the Bullion Canyon Volcanics. Best and Grant (1987) later correlated the Wallaces Peak with the Three Creeks, then abandoned the name Wallaces Peak in favor of Three Creeks; they also elevated the rank of Needles Range to a group. Some exposures of Three Creeks Tuff Member miscorrelated with the Needles Range Group (for example, Cunningham and others, 1983) are now recognized as the Three Creeks (in for example, Rowley and others, 1987; Steven and others, 1990). The Three Creeks Tuff Member is a light-gray and tan, moderately welded, crystalrich, dacitic ash-flow tuff that occurs in the lower part of the Bullion Canyon Volcanics and is spread over much of the southern High Plateaus and adjacent Great Basin. It probably was the largest ash-flow tuff from the Marysvale field and was derived from the Three Creeks caldera in the southern Pavant Range (Steven, 1981). A thin sequence of mostly volcanic mudflow breccia and conglomerate containing abundant clasts of the Three Creeks Tuff Member was mapped in a few places in the northern Sevier Plateau (Cunningham and others, 1983) and called the volcanic rocks of Cliff Canyon; it represents erosion of near-source Three Creeks rocks and should be included with the Bullion Canyon Volcanics. Similar clasts in mudflow and conglomerate beds at the same stratigraphic level have been seen in the southern Sevier Plateau (Rowley, 1968) and in the Brian Head Formation in the Red Hills (Florian Maldonado, written commun., 1993). Steven and others (1979) reported a series of K-Ar and fission-track mineral ages on the Three Creeks Tuff Member, two K-Ar dates (32.1 1.4 and $30.6 \pm 1.3 \mathrm{Ma}$, both on biotite) of which were rejected because they predate the underlying Wah Wah Springs Formation; K-Ar dates on plagioclase of $26.9 \pm 2.2$ and $28.9 \pm 1.3 \mathrm{Ma}$ and fission-track dates on zircon of $27.4 \pm 1.3$ and $27.0 \pm 1.2 \mathrm{Ma}$, however, are reasonable. In addition, Caskey and Shuey (1975) reported a K-Ar date on biotite of 27.5 $\pm 0.4 \mathrm{Ma}$. Kowallis and Best (1990) published a zircon fission-track date of $25.1 \pm 2.2 \mathrm{Ma}$ on a sample of the Three Creeks collected from western Utah. The average age of the six dates that we consider reliable is $27.1 \mathrm{Ma}$, our best estimate of the age of the member.

The Delano Peak Tuff Member was redefined by Steven and others (1979) from the Delano Peak Latite Member initially named by Callaghan (1939) that occurs in the upper part of the Bullion Canyon Volcanics. It is a dark-reddish-brown, densely welded, crystal-rich, dacitic ash-flow 
tuff whose distribution is largely confined to the Tushar Mountains. It was derived from the Big John caldera of the central Tushar Mountains (Steven, Cunningham, and Anderson, 1984). Steven and others (1979) determined three discordant dates on a single sample of the unit. One, a K-Ar date on biotite of $28.9 \pm 1.4 \mathrm{Ma}$, is suspect because it is older than the Three Creeks Tuff Member; another, a fission-track date on zircon of $21.8 \pm 1.0 \mathrm{Ma}$, is suspect because it is younger than the Osiris Tuff (see section, "Monroe Peak Caldera"), which stratigraphically overlies it. The third, a fission-track date on apatite of $23.7 \pm 3.6 \mathrm{Ma}$, has a larger error bar than the other two but is the most reasonable based on stratigraphic relationships and ages of underlying and overlying units. Our best estimate of the age of the Delano Peak is thus 24 $\mathrm{Ma}$, although it could be slightly younger. Steven, Cunningham, and Anderson (1984) published a fission-track date on zircon of $22.6 \pm 1.0 \mathrm{Ma}$, but it is suspect because it is numerically younger than the age of the overlying Osiris Tuff. Thick sequences of flows and breccia of the Bullion Canyon Volcanics overlie the Delano Peak Tuff Member.

\section{MOUNT DUTTON FORMATION}

The Oligocene and Miocene Mount Dutton Formation (Anderson and Rowley, 1975) makes up another complex assemblage of stratovolcano deposits that is comparable in thickness (about $1,500 \mathrm{~m}$ ) to, although more widespread and voluminous than, the Bullion Canyon Volcanics. The formation intertongues with the south edges of the Bullion Canyon Volcanics, and makes up the southern flank of the Marysvale field. The rocks are mostly andesite and subordinate dacite (Mattox and Walker, 1989; Mattox, 1992) and are in general more mafic than those of the Bullion Canyon. The Mount Dutton also differs from the Bullion Canyon in that in large part it contains sparse, small phenocrysts, mostly of pyroxene and plagioclase. These less evolved rocks apparently came from much deeper source magma chambers than the numerous consanguineous intrusions that fed and were emplaced into the Bullion Canyon Volcanics. Thus only dikes and sparse small plugs of the Mount Dutton Formation are presently exposed, as opposed to the large and abundant plutons associated with the Bullion Canyon Volcanics. Most of the clustered stratovolcano sources of the Mount Dutton Formation make up an east-trending belt along the Blue Ribbon lineament (Rowley, Lipman, and others, 1978), which extends from the northern Black Mountains eastward along the boundary between the southern Tushar Mountains and northern Markagunt Plateau and into parts of the southern Sevier Plateau. Most vents that have been mapped are spectacularly exposed locally (Blackman, 1985; Anderson, Rowley, Machette, and others, 1990; Anderson, Rowley, Blackman, and others, 1990) so that Anderson and coworkers were able in most places to separate vent-facies rocks from more distal alluvial-facies rocks. The formation can be subdivided in many places by thin ash-flow tuff members that serve as markers in the thick stratovolcano sequence. Lower parts of the formation underlie the Wah Wah Springs Formation, and upper parts overlie the Osiris Tuff (see p. 17). Fleck and others (1975) determined the following K-Ar ages on flows and dikes from within the Mount Dutton Formation: (1) $26.7 \pm 0.8 \mathrm{Ma}$ on hornblende from a lava flow (their sample R-19) from low in a section of vent-facies rocks in the southeastern Tushar Mountains; (2) 25.8 \pm 0.7 Ma on whole rock from a lava flow (sample R-5) from low in a section of alluvial-facies rocks in the northern Markagunt Plateau; (3) $23.5 \pm 0.4$ Ma on whole rock from a dike (sample R-23) of upper vent-facies rocks in the southern Tushar Mountains; (4) 23.0 $\pm 0.4 \mathrm{Ma}$ on biotite from a lava flow (sample R-24; incorrectly reported as the Osiris Tuff in Fleck and others, 1975) from high in a section of vent-facies rocks in the southwestern Tushar Mountains; and (5) $21.2 \pm 0.5 \mathrm{Ma}$ on whole rock from a lava flow (sample R-27) in alluvial-facies rocks that may represent an extrusive product of the Iron Peak intrusion (see section, "Calc-alkaline Intrusions") in the northern Markagunt Plateau but is mapped within the top of the Mount Dutton Formation. Mattox (1992) reported one K-Ar whole-rock date of $24.9 \pm 1.1$ Ma on a basalt lava flow of the Mount Dutton Formation from Little Creek Peak in the northern Markagunt Plateau.

The Beaver Member of the Mount Dutton Formation (Anderson and Rowley, 1975) is a sequence of crystal-rich dacitic volcanic domes and lava flows occurring low in the Mount Dutton Formation, above the Wah Wah Springs Formation. It is exposed in the northwestern Markagunt Plateau and eastern Black Mountains (Anderson, Rowley, Machette, and others, 1990). Fleck and others (1975) determined two $\mathrm{K}$-Ar dates on plagioclase from the member, $26.2 \pm 0.5$ (sample R-13) and 25.0 \pm 0.8 (sample R-15) Ma. Our best estimate of the age of the member is the average of the dates, 25.6 Ma.

The Kingston Canyon Tuff Member of the Mount Dutton Formation (Anderson and Rowley, 1975) is a thin, purple, densely welded, crystal-poor, trachytic ash-flow tuff occurring within alluvial-facies mudflow breccia in the Sevier Plateau and the southwestern Tushar Mountains; it is rarely exposed within vent-facies rocks. It overlies the Wah Wah Springs Formation and Three Creeks Member of the Bullion Canyon Volcanics in the lower part of the Mount Dutton sequence. Its source has not been discovered, but it is similar in petrology to the tuff of Albinus Canyon (see section, "Local Volcanic Centers") that is exposed in the general area of the town of Sevier. Although the source of that unit is also unknown, textural features in the Albinus Canyon rocks near Sevier suggest proximity here to its source, perhaps under the basin-fill sedimentary rocks of nearby Sevier Valley. Fleck and others (1975) determined a K-Ar date of $25.8 \pm 0.4 \mathrm{Ma}$ on biotite from the Kingston Canyon Tuff Member (sample R-1).

The Antimony Tuff Member of the Mount Dutton Formation (Anderson and Rowley, 1975) occurs above the 
Kingston Canyon Tuff Member, and volcanic mudflow breccia locally more than $300 \mathrm{~m}$ thick generally separates them. The Antimony Tuff Member is a thin, red, densely welded, crystal-poor trachytic ash-flow tuff similar to the Kingston Canyon Tuff Member, and it likewise is exposed mostly within alluvial-facies rocks in the Sevier Plateau. It is chemically and petrologically almost identical to the tuff of Albinus Canyon, on which it rests near Sevier (Rowley and others, 1988b), and thus it probably was derived from the same source as the tuff of Albinus Canyon. A new K-Ar date on sanidine from a sample (78-1288) of the Antimony Tuff Member collected from the central Sevier Plateau is 25.4 \pm 0.9 Ma (table 1). In addition to the Kingston Canyon and Antimony Tuff Members, a petrologically similar informal unit, the tuff member of Piute Reservoir, was mapped between Kingston and Antimony in the western part of the central Sevier Plateau (Rowley, Cunningham, and others, 1979).

\section{INTERTONGUED GREAT BASIN ASH-FLOW SHEETS}

Regional ash-flow tuff units derived from caldera sources in the Great Basin, generally southwest of the Marysvale field, are locally intertongued marginally with rocks of the Marysvale field, where they provide thin, welldated, distinctive stratigraphic markers. The tuff units are widespread southwest of the Marysvale field in southwestern Utah and southeastern Nevada (Mackin, 1960; Anderson and Rowley, 1975; Siders and Shubat, 1986; Best, Christiansen, and others, 1989; Best and others, 1993; Rowley, Nealey, and others, in press; Scott and others, in press). Many are intertongued with Marysvale rocks only in the southwestern part of the Marysvale field (in the southern Black Mountains and Markagunt Plateau); an exception is the Wah Wah Springs Formation, which is distributed over most of the Marysvale field (Rowley, Anderson, and others, 1978; Best, Christiansen, and Blank, 1989). Rowley, Anderson, and others (1978) suggested that the distribution pattern of the post-Wah Wah Springs tuffs was influenced by an early (26-24 Ma) episode of structural uplift of the Colorado Plateau with respect to the Great Basin. This suggestion was disputed by Anderson and Mehnert (1979), who provided evidence for east-sloping physiography across the Great Basin-Colorado Plateau boundary south of Cedar City, Utah, sometime following emplacement of plutons in the Pine Valley Mountains (21.5 Ma). Maldonado (in press) favored an easterly sloping northern Markagunt Plateau at about 21-20 Ma. Nonetheless, Great Basin tuffs pinch out along the southwest edges of the Marysvale field, so a regional paleoslope in this area to the west or southwest remains possible; such a west or southwesterly paleoslope could be due to structural control or to highlands caused by the locally derived Marysvale volcanic rocks. Of these alternatives, J.J. Anderson (1985, 1988, 1993) favored structural control by west-northwest-striking, southwest-facing fault scarps that formed after $26 \mathrm{Ma}$.

The oldest of the Great Basin tuff sheets in the Marysvale volcanic field is the widespread Wah Wah Springs Formation of the Needles Range Group (Mackin, 1960; Best and Grant, 1987). This is a light-gray, pink, and tan, moderately welded, crystal-rich, dacitic ash-flow tuff derived from the huge Indian Peak caldera straddling the Nevada-Utah State line and north of Modena (fig. 1) (Best, Christiansen, and Blank, 1989). The tuff generally rests on the Claron and Brian Head Formations and intertongues with lower parts of the Bullion Canyon Volcanics and Mount Dutton Formation. It extends even farther to the northeast into and north of the Marysvale field than the distribution shown by Best, Christiansen, and Blank (1989, fig. 5b; Best, Christiansen, and others, 1989, fig. R29) according to recent field and paleomagnetic studies by C.S. Grommé and M.G. Best (M.G. Best, written commun., 1993). The average K-Ar age of the Wah Wah Springs Formation is $29.5 \mathrm{Ma}$ (Best, Christiansen, and Blank, 1989), but unpublished ${ }^{40} \mathrm{Ar} /{ }^{39} \mathrm{Ar}$ dates indicate that the actual age is somewhat older than this (M.G. Best, written commun., 1993). E.G. Sable collected a 3-m-thick ash-flow tuff of the Wah Wah Springs Formation from the top part of what we now call the Brian Head Formation and a few meters below the Isom Formation, from Lowder Creek, about $3 \mathrm{~km}$ east-southeast of Brian Head (fig. 3). Four new dates on biotite and hornblende, respectively, on each of two samples from the same bed are: $30.4 \pm 3.1$ and $30.4 \pm 1.1$ $\mathrm{Ma}$ (sample USA60A) and 32.4 \pm 3.4 and $29.1 \pm 1.0 \mathrm{Ma}$ (sample USA60B) (table 1).

Above the Wah Wah Springs Formation, but exposed only in a few places in the Black Mountains and northern Markagunt Plateau (Best, Christiansen, and Blank, 1989; Best, Christiansen, and others, 1989), is the Lund Formation of the Needles Range Group. It resembles the Wah Wah Springs Formation but was derived from the White Rock caldera, which overlaps the west side of the Indian Peak caldera. The Lund Formation has an average isotopic age of 27.9 Ma (Best, Christiansen, and Blank, 1989), which accords with the average age of $27.1 \mathrm{Ma}$ that we determined for the overlying Three Creeks Tuff Member of the Bullion Canyon Volcanics.

The Isom Formation (Mackin, 1960) consists of numerous densely welded, crystal-poor, trachytic ash-flow tuff, tufflava, and lava flows. The source of the formation is unknown and probably buried by younger rocks, but based on isopach data it seems to be on the southeast side of the Indian Peak caldera (Best, Christiansen, and Blank, 1989). The formation is more than $200 \mathrm{~m}$ thick in much of southwestern Utah, including the western part of the northern Markagunt Plateau, but farther east and north it is thin; it is not present in the Tushar Mountains. The lowest member of the Isom Formation in the Markagunt Plateau is the Blue Meadows Tuff Member, a simple ash-flow cooling unit 
apparently restricted to the plateau. We have yet to find the Blue Meadows west of the Markagunt Plateau, in the direction of the source of the Isom Formation, so it is possible that it is a small local tuff derived from the Marysvale field and related to the lithologically similar Kingston Canyon and Antimony Tuff Members of the Mount Dutton Formation (J.J. Anderson, unpub. data, 1992). The Blue Meadows has a $\mathrm{K}$-Ar date on plagioclase of $25.9 \pm 0.4 \mathrm{Ma}$ (sample R-7; Fleck and others, 1975).

Most Isom cooling units in the southwestern Marysvale field and to the west are contained within the Baldhills Tuff Member, and they are mostly dark reddish brown and dark gray. The average K-Ar age of tuffs correlated with the Baldhills Member is 25.7 Ma based on two dates, one by Armstrong (1970) on whole rock of $25.7 \pm 0.5 \mathrm{Ma}$ (sample $160)$ and one by Fleck and others (1975) on plagioclase of $25.7 \pm 0.4 \mathrm{Ma}$ (sample R-8). Scott and others (in press) recently published a plagioclase $\mathrm{K}-\mathrm{Ar}$ date of $25.9 \pm 0.8 \mathrm{Ma}$ determined by H.H. Mehnert on a Baldhills sample from the Delamar Mountains of Nevada. These ages, however, may have been superseded by a ${ }^{40} \mathrm{Ar} /{ }^{39} \mathrm{Ar}$ date of about $27 \mathrm{Ma}$ on the Baldhills published by Best, Christiansen, and others (1989; fig. R1; no analytical data yet published). This date is similar to ${ }^{40} \mathrm{Ar} /{ }^{39} \mathrm{Ar}$ date on plagioclase of $27.4 \pm 2.5 \mathrm{Ma}$ for the "tuff of Hamilton Spring" (Taylor and others, 1989), a unit correlated on the basis of paleomagnetic data and petrology with the Baldhills Tuff Member (C.S. Grommé, written commun., 1989). The uppermost member of the Isom Formation is the Hole-in-the-Wall Tuff Member, an undated, red, simple cooling unit that, unlike the Baldhills, was recognized by C.S. Grommé to overlie the Shingle Pass Tuff of Nevada (Scott and others, in press); the upper cooling unit of the Shingle Pass Tuff has a ${ }^{40} \mathrm{Ar} /{ }^{39} \mathrm{Ar}$ date of $26.0 \mathrm{Ma}$ (Best, Christiansen, and others, 1989, table R3; analytical data not published). The discrepancy of the Ar ages with the concordant K-Ar ages suggests that the samples of the "Baldhills" dated by the K-Ar method are from upper parts of the Baldhills Tuff Member or are from the Hole-in-the-Wall Tuff Member. The ages on the Blue Meadows suggest that it is mapped in the upper part of the Baldhills west of the Markagunt Plateau.

A series of ash-flow tuff units belonging to the Quichapa Group (Williams, 1967; Anderson and Rowley, 1975) are exposed along the southwestern margin of the Marysvale field. The oldest of these is the Leach Canyon Formation, a tan, poorly welded, crystal-poor, rhyolite ashflow tuff whose source is not known but which, on the basis of isopach data (Williams, 1967), may be near the north side of the Caliente caldera complex of Nevada-Utah, about 180 $\mathrm{km}$ southwest of Marysvale. The average age of the Leach Canyon Formation is $24.0 \mathrm{Ma}$, on the basis of three $\mathrm{K}-\mathrm{Ar}$ dates $(26.7 \pm 1.0 \mathrm{Ma}$ on plagioclase from a sample from Nevada and $24.6 \pm 0.5 \mathrm{Ma}$ on biotite and $22.9 \pm 0.5 \mathrm{Ma}$ on sanidine from a sample from Utah) by Armstrong (1970) and two zircon fission-track dates $(24.2 \pm 2.0 \mathrm{Ma}$ from a sample from Utah and 21.6 $\pm 2.0 \mathrm{Ma}$ from a sample from Nevada) by Kowallis and Best (1990). These discordant ages make it impossible for us to determine the actual age of the tuff at this time. Preliminary Ar dates obtained by A.L. Deino and M.G. Best (oral commun., 1991), however, suggest an age of 23.8 Ma, Miocene (Best and others, 1993).

The Condor Canyon Formation of the Quichapa Group consists of two dark-reddish-brown, densely welded, crystalpoor, rhyolite ash-flow tuff units, from older to younger the Swett Tuff Member and the Bauers Tuff Member. The Bauers Tuff Member and probably the Swett Tuff Member were derived from the Clover Creek caldera, near Caliente in the Caliente caldera complex (Rowley and Siders, 1988; Rowley, Anderson, and others, 1990; Rowley and others, 1992). The average isotopic age of the Swett is $23.7 \mathrm{Ma}$, representing six K-Ar dates on biotite and plagioclase by Armstrong (1970). The average K-Ar age of the Bauers is 22.3 Ma from two determinations on biotite and sanidine by Armstrong (1970) and one on plagioclase by Fleck and others (1975), but these ages have been supplanted by more precise ${ }^{40} \mathrm{Ar} /{ }^{39} \mathrm{Ar}$ determinations that average $22.78 \mathrm{Ma}$ (Best, Christiansen, and others, 1989, table R3; no analytical data yet published). A similar unpublished ${ }^{40} \mathrm{Ar} /{ }^{39} \mathrm{Ar}$ date on sanidine of $22.8 \pm 0.1 \mathrm{Ma}$ by L.W. Snee was obtained from a sample from the intracaldera pluton in the Clover Creek caldera (Rowley, Shroba, and others, in press).

The Harmony Hills Tuff, the youngest unit of the Quichapa Group, is a light-gray and pink, moderately welded, crystal-rich, high-alkali andesite ash-flow tuff. The caldera source has not been found, but isopach and distribution data suggest that it is in the Bull Valley Mountains of Utah (Blank, 1959; Williams, 1967; H.R. Blank, oral commun., 1990). The average K-Ar age of the Harmony Hills Tuff is $21.6 \mathrm{Ma}$ from five dates on biotite and plagioclase by Armstrong (1970) and one on biotite by Noble and McKee (1972); the actual age, however, is probably 22.5 to $22 \mathrm{Ma}$ on the basis of isotopic ages of plutons and ash-flow tuff units in the Iron Springs mining district (Rowley and others, 1989) that postdate the Harmony Hills.

\section{LOCAL VOLCANIC CENTERS}

The Marysvale volcanic field contains numerous local calc-alkaline volcanic centers whose products were mapped separately from the Bullion Canyon Volcanics and Mount Dutton Formation. Centers include stratovolcanoes, volcanic domes, shield volcanoes, and tuff vents, and they consist of lava flows, flow breccia, volcanic mudflow breccia, and tuff. The oldest rocks belong to an andesitic to dacitic vent- and alluvial-facies sequence of probable stratovolcano origin that underlies the Three Creeks Tuff Member of the Bullion Canyon Volcanics in the southern Pavant Range. These were mapped as informal units at 1:50,000 by Cunningham and others (1983) as the volcanic rocks of Dog Valley and the 
overlying volcanic rocks of Wales Canyon; during compilation at 1:250,000, Steven and others (1990) lumped them with the Bullion Canyon Volcanics. The volcanic rocks of Dog Valley are at least $400 \mathrm{~m}$ thick; the Wah Wah Springs Formation is shown intertongued in the middle of the section by Cunningham and others (1983), but we now correlate this tuff with the Three Creeks Tuff Member. A lava flow in the lower part of the volcanic rocks of Dog Valley below the Three Creeks Tuff Member yielded a fission-track date on zircon of 33.6 $\pm 2.6 \mathrm{Ma}$ (Kowallis and Best, 1990). The volcanic rocks of Wales Canyon, with a thickness of at least 200 $\mathrm{m}$, occur between the Wah Wah Springs Formation and the Three Creeks Tuff Member. About $7 \mathrm{~km}$ west of Joseph, also in the southern Pavant Range, a dacitic center at least $6 \mathrm{~km}$ in diameter, probably a volcanic dome complex, formed after deposition of the volcanic rocks of Wales Canyon and before deposition of the Three Creeks Tuff Member. This complex was mapped informally as a quartz latite and rhyodacite volcanic dome and flow (unit Tqd) by Cunningham and others (1983). The complex remained a topographic highland during later deposition of the Three Creeks Tuff Member, which pinched out against it.

A thick sequence of andesite and basaltic andesite lava flows, flow breccia, and volcanic mudflow breccia that overlies the Three Creeks Tuff Member makes up a volcanic plateau and shield volcano in the northern Sevier Plateau. This sequence has been called informally the volcanic rocks of Signal Peak and is at least $1,000 \mathrm{~m}$ thick. The Antimony Tuff Member is intertongued with lava flows in the middle and upper part of the sequence. To the west, in the Antelope Range, the Osiris Tuff ( $23 \mathrm{Ma}$ ) overlies similar basaltic andesite lava flows, as much as $50 \mathrm{~m}$ thick, that in most places rest on the Antimony Tuff Member, which in turn rests on the tuff of Albinus Canyon (Rowley and others, 1988b). In the southeastern Pavant Range, the basaltic andesite is thicker and overlies the tuff of Albinus Canyon, although some of the basaltic andesite may intertongue with the tuff of Albinus Canyon, which in turn overlies the Three Creeks Tuff Member. The volcanic rocks of Signal Peak are extensive east of the area we have mapped (Rowley and others, 1986b) and were previously mapped as the latite and basaltic andesite flows undifferentiated unit of Williams and Hackman (1971).

A new whole-rock K-Ar date of 21.6 $\pm 1.0 \mathrm{Ma}$ (table 1) on basaltic andesite (sample 79-S-3) that overlies the tuff of Albinus Canyon in the southeastern Pavant Range is surprisingly young because in the northern Antelope Range $5 \mathrm{~km}$ to the southeast, lithologically similar basaltic andesite underlies the Osiris Tuff. This calc-alkaline basaltic andesite may represent late volcanism that formed the volcanic rocks of Signal Peak. The date indicates that at least some of the basaltic andesite is the same age as the potassium-rich mafic volcanic rocks (see section of this name). However, the chemistry of the basaltic andesite is distinctly different from that of both the potassium-rich mafic volcanic rocks and the tuff of Albinus Canyon; thus they are mapped separately (Cunningham and others, 1983).

The tuff of Albinus Canyon consists of numerous thin cooling units, as much as $200 \mathrm{~m}$ thick, of red and gray, vesicular, densely welded, crystal-poor, trachytic ash-flow tuff, tufflava, and basaltic andesite lava flows. The tuffs and tufflavas resemble those of the Isom Formation as well as the Kingston Canyon and Antimony Tuff Members of the Mount Dutton Formation. A new K-Ar date on plagioclase (sample M739) from the tuff of Albinus Canyon in the Pavant Range is $25.3 \pm 1.3$ Ma (table 1); this is concordant, within analytical error, with dates on the Kingston Canyon and Antimony. The tuff of Albinus Canyon is considered a proximal accumulation from a nearby source that also erupted the Kingston Canyon and Antimony Tuff Members. The similarity in composition, appearance, and age of the tuff of Albinus Canyon and the Kingston Canyon and Antimony Tuff Members with the units of the Isom Formation and other units from sources in Nevada is a regional petrologic problem about which we and others currently are perplexed. Best, Christiansen, and others (1989) have discussed the Isom compositional type of tuff and other compositional types and have suggested that they represent magmas in different areas that had similar origins and crystallization histories.

In the central and northern Sevier Plateau, products of several stratovolcanoes and shield volcanoes were mapped (Cunningham and others, 1983) between the Bullion Canyon Volcanics to the north and west and the Mount Dutton Formation to the south. The oldest of these, the volcanic rocks of Little Table, consists of andesitic and trachyandesitic lava flows, flow breccia, and volcanic mudflow breccia making up a volcanic plateau derived from either a stratovolcano or a shield volcano. Both vent- and alluvial-facies rocks were mapped, with a total thickness at any one place of at least 700 $\mathrm{m}$. The unit overlies the Three Creeks Tuff Member of the Bullion Canyon Volcanics and intertongues with the Mount Dutton Formation, including the Kingston Canyon and Antimony Tuff Members. The upper part of the volcanic rocks of Little Table intertongues with and is overlain by two local, informally named stratovolcano sequences, one a dacitic to andesitic alluvial-facies sequence named the volcanic rocks of Willow Spring, at least $150 \mathrm{~m}$ thick, and the other a trachyandesitic to trachydacitic alluvial- and vent-facies sequence named the volcanic rocks of Langdon Mountain, at least $400 \mathrm{~m}$ thick. These two units postdate the Antimony Tuff Member of the Mount Dutton Formation and predate the Osiris Tuff. The volcanic rocks of Little Table, Willow Spring, and Langdon Mountain are probably more extensive east of our area of detailed mapping (Rowley and others, 1986a, b; Mattox, 1991a), where only reconnaissance maps are now available (Williams and Hackman, 1971).

A series of shallow calc-alkaline laccoliths unrelated to Mount Dutton magmatism were emplaced into the Claron Formation in the northern Markagunt Plateau and adjacent 
areas (Anderson and Rowley, 1975). These laccoliths are south of the area of Mount Dutton sources, and they were intruded in a region where alluvial-facies Mount Dutton volcanic rocks are relatively thin. The largest of these laccoliths is the Spry intrusion (described in detail in the section, "Calc-alkaline Intrusions"), which is consanguineous with an overlying dacitic central vent complex consisting of lava flows and tuff; the deposits of the vent complex intertongue with the lower part of the Mount Dutton Formation (Anderson, Rowley, Blackman, and others, 1990). During and after volcanic eruptions, the Spry intrusion invaded the lower part of the related volcanic edifice. The central vent complex is exposed in unnamed hills between the northern Markagunt Plateau on the west and the southern Sevier Plateau on the east, about $15 \mathrm{~km}$ south-southwest of Circleville. The central vent complex is on the northeast side of the Spry intrusion and consists of as much as $250 \mathrm{~m}$ of lava flows, dikes, volcanic mudflow breccia, sandstone, and tuff, probably including the Buckskin Breccia (see next paragraph). This vent complex is informally named the volcanic rocks of Bull Rush Creek (Anderson, Rowley, Blackman, and others, 1990). Two K-Ar dates determined on a sample from a glassy dike of the unit were first reported by Anderson, Rowley, Blackman, and others (1990) and are repeated here (table 1, sample 84-259). One of these dates, $29.4 \pm 2.2 \mathrm{Ma}$ on hornblende, is rejected because it is considered too old due to excess argon; the other, $26.4 \pm 3.2 \mathrm{Ma}$ on plagioclase from the same sample, is geologically reasonable and is similar to a new date on the Spry intrusion (see following).

The most widespread product of the Spry intrusion vent complex is the Buckskin Breccia (Anderson and Rowley, 1975), which consists of at least five cooling units of a tan and light-gray, poorly welded, crystal-poor, dacitic ash-flow tuff that spread over much of the northern Markagunt Plateau and southern Sevier Plateau (Yannacci, 1986). Eruption of the Buckskin Breccia may have produced a caldera, but none has been found. The Buckskin Breccia is distinctive in that it is characterized by as much as 50 percent by volume of cognate lithic fragments of white, crystal-rich flow rocks that are petrologically similar to quartz monzonite porphyry of the Spry intrusion and to flows and dikes of the volcanic rocks of Bull Rush Creek. The Buckskin Breccia, which overlies and intertongues with rocks of the Isom Formation, exhibits large thickness variations, from zero to $250 \mathrm{~m}$, because it fills westnorthwest-striking grabens that formed after emplacement of the Isom (Anderson, 1965, 1971, 1993). The Buckskin Breccia probably dates at $26 \mathrm{Ma}$ because it interfingers with some cooling units of the Isom Formation (Anderson, Rowley, Machette, and others, 1990) and because of dates of this age on the Spry intrusion (described in a subsequent section) and volcanic rocks of Bull Rush Creek. The youngest age of the Buckskin Breccia is constrained by the overlying Bear Valley Formation, an eolian sandstone locally more than $300 \mathrm{~m}$ thick that filled the remainder of some of the grabens (Anderson, 1971). Fleck and others (1975) determined two K-Ar dates on tuff beds in the upper part of the Bear Valley Formation, one of $24.6 \pm 0.4 \mathrm{Ma}$ from biotite from an airfall tuff (sample R-10) and one of $24.5 \pm 0.5 \mathrm{Ma}$ from plagioclase from a crystal-poor ash-flow tuff (sample R-9). Armstrong (1970) determined two K-Ar dates on separates of hornblende-bearing biotite from the "Rodger (sic) Park [Basaltic] Breccia" (a stratigraphic name proposed by Callaghan and Parker, 1962a, but abandoned by Anderson and Rowley, 1975) from the northern Markagunt Plateau of $26.5 \pm 0.5$ and $27.9 \pm 0.6$ Ma. The coordinates Armstrong gave for these dates, when plotted on geologic maps of the area (Anderson and Rowley, 1987, and Anderson and others, 1987, respectively), leave unclear exactly what unit he dated, but the presence of biotite and hornblende that he reported in the sample suggests that the unit is the Buckskin Breccia.

The relative ages of the Bear Valley and Leach Canyon Formations are not known because, where exposed together in the Red Hills west of the Markagunt Plateau, they are in fault contact along bedding-parallel low-angle faults (Red Hills shear zone of Maldonado and others, 1992; Maldonado, in press) and in the Markagunt megabreccia (Anderson, 1993) that are partly within soft beds of the Bear Valley Formation. Isotopic ages so far determined suggest, however, that the Leach Canyon is younger than the Bear Valley. Yet deposition of eolian sand apparently continued after deposition of the type Bear Valley Formation. In the southern Black Mountains (Rowley, 1978), thin Bear Valley-type sandstone interfingers between two ash-flow cooling units of the Leach Canyon Formation, and eolian sandstone lenses lithologically similar to the Bear Valley Formation have been mapped from levels above the Isom Formation to well up in the Mount Dutton Formation (for example, Anderson, Rowley, Blackman, and others, 1990).

Local volcanic centers are exposed about $8 \mathrm{~km}$ east of Beaver, in the southwestern Tushar Mountains. The oldest center erupted the tuff of Lion Flat, a light-gray, unwelded, crystal-poor, rhyolite ash-flow tuff (Cunningham and others, 1983) that overlies the Osiris Tuff (see p. 17). The center (Wickstrom, 1982) was suggested to be a small caldera (Steven, Rowley, and Cunningham, 1984), but more likely the tuff of Lion Flat represents tuff-ring deposits associated with an overlying trachydacite volcanic dome because the tuff contains clasts of dome rock (C.G. Cunningham, unpub. data, 1993). This dome is about $8 \mathrm{~km}$ in diameter and exhibits spectacularly exposed vertical flow foliation. Originally mapped within the Dry Hollow Formation (Callaghan and Parker, 1962a), the dome was briefly described under this name by Anderson and Rowley (1975), but later detailed study indicated that a local name was more appropriate (Sigmund, 1979). The name Dry Hollow Formation was abandoned by Steven and others (1979), who found that rocks previously mapped as that unit were correlated with several other units. Following the suggestions of Sigmund, the rocks of the dome are called informally the formation of Lousy Jim (Cunningham and others, 1983). Fleck and others (1975) 
determined two K-Ar dates on the unit, one of $22.4 \pm 0.4 \mathrm{Ma}$ on sanidine (sample R-16) and the other of $22.3 \pm 0.4 \mathrm{Ma}$ on biotite (sample R-32).

The youngest of the local accumulations of calc-alkaline rocks in the southern Tushar Mountains is called the lava flows of Kents Lake (Anderson, Rowley, Blackman, and others, 1990). These flows overlie the Mount Dutton Formation, uppermost parts of which contain the Osiris Tuff. The main rock type is strongly flow layered, porphyritic andesite, accumulating to thicknesses of as much as $250 \mathrm{~m}$.

A local, recently recognized, densely welded ash-flow tuff, whose source is unknown but which is confined to the central Markagunt Plateau, was defined by Anderson (1993) as the Haycock Mountain Tuff. The tuff is significant because it is reported by Anderson to overlie the Markagunt megabreccia, a major gravity-slide deposit that is widely exposed in the central and northern Markagunt Plateau (Sable and Anderson, 1985; Anderson, 1993). The Markagunt megabreccia is one of several large Tertiary deformational features in the southern High Plateaus and Red Hills; others of these are the 22.5-20 Ma shallow, low-angle, extensional Red Hills shear zone (Maldonado and others, 1989, 1990, 1992; Maldonado, in press) and 30-20 Ma thinskinned thrust faults (Davis and Krantz, 1986; Lundin and Davis, 1987; Lundin, 1989; Bowers, 1990; Nickelsen and Merle, 1991; Merle and others, 1993). All or some of these structural features may have a common denominator, namely the emplacement of a major shallow batholith (H.R. Blank, oral commun., 1991) centered under the area west of Spry and Panguitch (see section, "Calc-alkaline Intrusions"). A new K-Ar date (sample 89USA2A, collected by E.G. Sable) on biotite from the Haycock Mountain Tuff is $22.3 \pm 1.1 \mathrm{Ma}$ (table 1), but new K-Ar dates on another sample (89USA1A) are discordant, at $22.8 \pm 1.1 \mathrm{Ma}$ on biotite and $24.8 \pm 1.0 \mathrm{Ma}$ on sanidine (table 1 ). The discordant sanidine date is here rejected, and we currently are making ${ }^{40} \mathrm{Ar} /{ }^{39} \mathrm{Ar}$ analyses of the separates as well as chemical studies of the tuff itself, which petrographically is similar to the Leach Canyon Formation.

A local sequence of "latite" lava flows was mapped by Williams and Hackman (1971) in the eastern Awapa Plateau at the east edge of the Marysvale field. Rocks of these flows were chemically analyzed by Mattox (1991a), who showed them to be trachyte. Mattox (1991a) reported a K-Ar date on

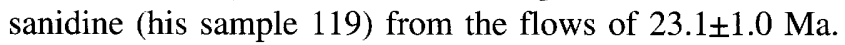
Because these rocks are similar in chemistry (Mattox, 1991a) and age to the Osiris Tuff, they were visited by P.D. Rowley in October 1992, who also concluded that the flows were from a small local volcanic center.

\section{MONROE PEAK CALDERA}

The Monroe Peak caldera in the northern Sevier Plateau is the largest caldera $(17 \times 26 \mathrm{~km})$ in the Marysvale field (fig. 3). The caldera formed from eruption of the Osiris Tuff on the site of a high volcanic plateau built during terminal stages of eruption of the Bullion Canyon Volcanics, volcanic rocks of Little Table, and volcanic rocks of Willow Spring; and the caldera formed against volcano edifices then being built on the east side of the plateau during deposition of the volcanic rocks of Signal Peak and of Langdon Mountain. The map of the western and central part of the caldera was compiled by Cunningham and others (1983), and the eastern part was mapped by Rowley and others (1986a, b), after which we realized that the western part underlies the Marysvale mining district. Consequently Rowley and others (1988a, b) remapped the western part of the caldera. Steven, Rowley, and Cunningham (1984) summarized the geology of the caldera.

The caldera subsided in response to its eruption of the trachytic Osiris Tuff, one of the most widespread ash-flow units in the volcanic field. The Osiris was informally recognized by Williams and Hackman (1971) and defined by Anderson and Rowley (1975). Fleck and others (1975) determined three concordant K-Ar dates on biotite from the Osiris Tuff, $23.4 \pm 0.4$ (sample R-3), $22.7 \pm 0.4$ (sample R-12), and $22.9 \pm 0.4$ (sample ES-1) Ma; our best estimate of the age of the Osiris is their average, 23.0 Ma. The isotopic ages of the Osiris Tuff and the Delano Peak Tuff Member of the Bullion Canyon Volcanics are similar, and Cunningham and others (1983) interpreted the Osiris Tuff to be older. Later field work by Rowley and J.J. Anderson in the Puffer Lake area of the Tushar Mountains, however, discovered a stratigraphic section containing both units that indicates that the Osiris is the younger.

The Osiris Tuff extends southwestward to the southeastern Black Mountains (Anderson, Rowley, Machette, and others, 1990), where its southwestern known occurrence overlaps the northeasternmost known occurrence of the Bauers Tuff Member of the Condor Canyon Formation (Rowley, 1978). The Bauers is virtually identical in lithology, petrology, and isotopic age to the Osiris Tuff, but their relative ages are unknown; they are another example of a petrologic type of tuff erupted from different places at the same time. Two ash-flow cooling units confined to the area near Beaver and formerly called the "tuff of Black Mountain" and "tuff of Beaver River" (Machette and others, 1984) were later correlated on the basis of detailed petrography with the Osiris Tuff (Lanigan and Anderson, 1987; Anderson, Rowley, Machette, and others, 1990a); the terms "tuff of Black Mountain" and "tuff of Beaver River" are abandoned.

Most of the fill in the Monroe Peak caldera consists of thick, deeply hydrothermally altered Osiris ash-flow tuff, locally interbedded with breccia and megabreccia beds as thick as $250 \mathrm{~m}$ that resulted from collapse of caldera walls. Alteration was caused by emplacement of abundant intracaldera intrusions, discussed in the following section. The uppermost part of the intracaldera fill, however, consists 
of a series of mostly fresh dacitic and andesitic lava flows and volcanic domes as much as $400 \mathrm{~m}$ thick. Several new isotopic determinations constrain the age of these rocks. Somewhat discordant K-Ar dates of a sample (M678) of a plagioclase- and sanidine-rich, dacitic lava flow sequence from $17 \mathrm{~km}$ northeast of Marysvale, near the top of the fault scarp that defines the west edge of the Sevier Plateau, are $21.8 \pm 0.8 \mathrm{Ma}$ on biotite and $20.3 \pm 0.8 \mathrm{Ma}$ on sanidine (table 1). Another sample (M718) from the same map unit but exposed in the western part of the caldera in Sevier Valley yielded a K-Ar date on sanidine of $21.3 \pm 0.7$ and a fissiontrack date on zircon of $15.3 \pm 1.4 \mathrm{Ma}$ (modified from preliminary dates published by Rowley and others, 1988b); the new and published analytical data are given in tables 1 and 2 . The fission-track age probably represents resetting by a buried rhyolitic or granitic intrusion of the Mount Belknap Volcanics near the sample site; the best age of the unit thus is the average of the three K-Ar dates, 21.1 Ma. New K-Ar dates were also determined from a sample (83-602) of another map unit, a sanidine-rich, dacitic, lava flow sequence near the top of the caldera fill in the eastern part of the caldera but whose relative age with respect to the plagioclase- and sanidine-rich flows is not known. These dates are $22.6 \pm 1.0 \mathrm{Ma}$ on biotite and $22.3 \pm 0.8 \mathrm{Ma}$ on sanidine (table 1 ), for an average age of $22.5 \mathrm{Ma}$. These ages suggest that volcanism in the caldera was quite long lived, extending perhaps as long as almost $2 \mathrm{~m} . y$. after the initial eruption of the Osiris Tuff, with apparently the youngest volcanism in the western part of the caldera.

Although some of the uppermost dacitic and andesitic flows and domes were locally intruded and resurgently domed by late consanguineous intracaldera intrusions; most intracaldera flows and domes were deformed into a gentle saucer-shaped structural basin that extends over the full width of the caldera. Some of the intracaldera intrusions came to within several hundred meters of the paleosurface; other intrusive masses probably were continuous upward with lava flows and domes in the upper part of the caldera fill.

\section{CALC-ALKALINE INTRUSIONS}

A shallow Cenozoic composite batholith underlies the central part of the Marysvale volcanic field and extends westward under other parts of the Pioche-Marysvale igneous belt (Steven, Rowley, and Cunningham, 1984, fig. 2; Steven and others, 1990; Steven and Morris, 1987). Cupolas of various ages, generally progressively younger toward the east, extended upward to shallow depths; some of these are partly exposed. Most of the exposed intrusive rocks are crystal-rich porphyries ranging in composition from granite through predominant quartz monzonite to diorite. All calderas in the Marysvale field occur above the batholith complex; the calderas probably represent foundered roofs of cupolas.
Table 2. Data for fission-track dates, Marysvale volcanic field and adjacent areas, Utah.

\begin{tabular}{|c|c|c|c|c|c|}
\hline $\begin{array}{l}\text { Rock unit, sample No. } \\
\text { (fig. 3), mineral } \\
\text { analyzed }^{1}\end{array}$ & ${ }^{2} \rho s$ & ${ }^{3} \rho \mathrm{i}$ & ${ }^{4} \phi \times 10^{15}$ & $\begin{array}{c}\mathrm{U} \\
(\mathrm{ppm})\end{array}$ & $\begin{array}{l}\text { Age in m.y. } \\
\quad \pm 2 \sigma\end{array}$ \\
\hline \multicolumn{6}{|l|}{$\begin{array}{l}\text { Intrusions of Mount } \\
\text { Belknap Volcanics }\end{array}$} \\
\hline M684A; Z & $\begin{array}{c}2.42 \\
(347)\end{array}$ & $\begin{array}{l}7.73 \\
(555)\end{array}$ & 1.03 & 220 & $19.2 \pm 2.8$ \\
\hline M693; Z & $\begin{array}{l}5.62 \\
(781)\end{array}$ & $\begin{array}{c}17.21 \\
(1,195)\end{array}$ & 1.02 & 490 & $19.9 \pm 2.0$ \\
\hline \multicolumn{6}{|l|}{ Calc-alkaline stock } \\
\hline M290; Z & $\begin{array}{c}2.08 \\
(529)\end{array}$ & $\begin{array}{l}3.53 \\
(449)\end{array}$ & 0.61 & 80 & $21.5 \pm 2.9$ \\
\hline \multicolumn{6}{|l|}{$\begin{array}{c}\text { Lava flows, Monroe } \\
\text { Peak caldera }\end{array}$} \\
\hline M718; Z & $\begin{array}{c}5.78 \\
(1,017)\end{array}$ & $\begin{array}{c}23.07 \\
(2,029)\end{array}$ & 1.02 & 650 & $15.3 \pm 1.4$ \\
\hline \multicolumn{6}{|l|}{$\begin{array}{c}\text { Intrusion, Monroe } \\
\text { Peak caldera }\end{array}$} \\
\hline M569; A & $\begin{array}{c}.092 \\
(189)\end{array}$ & $\begin{array}{l}.272 \\
(566)\end{array}$ & 1.00 & 7.8 & $20.0 \pm 4.1$ \\
\hline M569; Z & $\begin{array}{c}3.58 \\
(811) \\
\end{array}$ & $\begin{array}{c}9.47 \\
(1,074)\end{array}$ & .954 & 290 & $21.4 \pm 2.2$ \\
\hline \multicolumn{6}{|c|}{$\begin{array}{l}{ }^{1} \mathrm{Z}, \text { zircon, A, apatite. } \\
{ }^{2} \mathrm{ps} \text {, tracks } / \mathrm{cm}^{2} \text { fossil, } \times 10^{6} ; \text { (number of tracks counted). } \\
{ }^{3} \mathrm{pi} \text {, tracks } / \mathrm{cm}^{2} \text { induced, } \times 10^{6} ; \text { (number of tracks counted). } \\
{ }^{4} \phi \text {, neutrons } / \mathrm{cm}^{2} \text {. } \\
{ }^{5} \lambda_{\mathrm{F}}=7.03 \times 10^{-17} / \mathrm{yr} \text {. }\end{array}$} \\
\hline
\end{tabular}

SAMPLE DESCRIPTIONS

M684A. Small rhyolite stock near the Trinity mine, east of Big Rock Candy Mountain; lat $38^{\circ} 30^{\prime} 58^{\prime \prime} \mathrm{N}$., long $112^{\circ} 15^{\prime} 18^{\prime \prime} \mathrm{W}$.

M693. East-west glassy rhyolite dike that cuts the fine-grained granite in the Central Mining Area (shown by Rowley and others, 1988b); lat $38^{\circ} 30^{\prime} 15^{\prime \prime}$ N., long $112^{\circ} 13^{\prime} 05^{\prime \prime} \mathrm{W}$. Preliminary data published by Rowley and others $(1988 \mathrm{~b})$.

M290. Small porphyritic rhyodacite stock north of Deer Trail Mountain, from about $0.5 \mathrm{~km}$ south of Pine Creek at the east entrance of Bullion Canyon; lat $38^{\circ} 25^{\prime} 47^{\prime \prime}$ N., long $112^{\circ} 17^{\prime} 53^{\prime \prime} \mathrm{W}$.

M718. Lava flows of Monroe Peak, within Monroe Peak caldera, reset by an underlying pluton of bimodal magmatism, from $9.6 \mathrm{~km}$ south-southeast of Joseph (shown by Rowley and others $1988 \mathrm{~b}$ ); lat $38^{\circ} 32^{\prime} 30^{\prime \prime}$ N., long $112^{\circ} 10^{\prime} 40^{\prime \prime} \mathrm{W}$. Preliminary data published by Rowley and others (1988b). See also K-Ar date of this sample in table 1.

M569. Holocrystalline quartz monzonite porphyry, an intracaldera intrusion of the Monroe Peak caldera, from Dry Canyon, Sevier Plateau; lat $38^{\circ} 31^{\prime} 58^{\prime \prime}$ N., long $112^{\circ} 07^{\prime} 35^{\prime \prime} \mathrm{W}$.

Small, shallow, intermediate-composition, porphyritic intrusions are exposed in scattered places throughout the Tushar Mountains. Most cut the Bullion Canyon Volcanics and probably represent upward extensions of magma chambers that were the source of the Bullion Canyon. South of Cove Fort, in the northwestern Tushar Mountains (Steven and Morris, 1983), the intrusions cut rocks of the Bullion Canyon Volcanics, including the Three Creeks Tuff Member ( $27 \mathrm{Ma}$ ) and rocks as young as the tuff of Albinus Canyon $(25.5 \mathrm{Ma})$; the intrusive rocks are unconformably overlain by the Osiris Tuff. Similar stocks cutting the Bullion Canyon Volcanics were mapped by Machette and others (1984) farther south, along the western front of the Tushar Mountains, and by Cunningham and others (1983) in other parts of the range. Some stocks altered and mineralized their adjacent wallrocks, resulting in precious-metal deposits (Cunningham, Steven, Campbell, and others, 1984; Steven and Morris, 1987). One such stock of propylitized quartz monzonite 
in the northern Tushar Mountains contains the major epithermal gold-quartz-pyrite-carbonate veins of the Kimberly district (Cunningham, Steven, Campbell, and others, 1984); the stock yielded a fission-track date on zircon of $24.1 \pm 1.2$ Ma (Steven and others, 1979). The Indian Creek quartz monzonite stock in the western Tushar Mountains, with epithermal gold-quartz-pyrite veins developed at the Rob Roy mine, is of unknown age; fission-track dates from samples from the stock were reset by intrusions of younger bimodal rocks (Cunningham, Rye, and others, 1984) (see section, "Silicic Intrusions"). One intrusion, called the Hoover pluton by Rowley and others (1988b), located about $7 \mathrm{~km}$ north of Marysvale, may have localized minor amounts of copper in marginal contact-metamorphosed sedimentary rocks at the Trinity mine (Kerr and others, 1957) and developed spectacularly colorful hydrothermally altered rocks at a local tourist attraction named Big Rock Candy Mountain. The intrusion is truncated by the margin of the Monroe Peak caldera. Uranium mineralization was related to emplacement of a small stock of the Mount Belknap Volcanics near the Trinity mine, as discussed on page 25 .

The most extensive exposures of intrusive rocks in the Marysvale field are associated with the youngest calc-alkaline caldera, the Monroe Peak caldera. Several intrusions were separated in the mapping of the Marysvale mining district in the western part of the caldera, whereas elsewhere in the caldera the rocks were not divided into individual plutons (Cunningham and Steven, 1979b; Cunningham and others, 1983; Steven, Rowley, and Cunningham, 1984; Rowley and others, 1986a, b, 1988a, b). Most rocks are monzonite and quartz monzonite porphyry and have textures that range from coarse grained in pluton interiors to fine grained near intrusive contacts; at their contacts, they are difficult to distinguish from hydrothermally altered, cogenetic Osiris Tuff intracaldera fill into which the intrusions are emplaced. Fission-track dates from sample M569 of holocrystalline rock from an interior zone of an intracaldera intrusion in Dry Canyon, at the west edge of the northern Sevier Plateau, are modified from preliminary dates on this sample first reported by Rowley and others (1988b) and are given in table 2: $21.4 \pm 2.2$ Ma from zircon and 20.0 $\pm 4.1 \mathrm{Ma}$ from apatite. The zircon age is considered to represent the true age of the intrusive rock. It compares favorably with the ages of the intracaldera lava flows and domes that occur at the top of the caldera fill that are cogenetic with the undivided intrusive rocks. The zircon age, in conjunction with these volcanic ages, demonstrates that intracaldera volcanism and intrusion continued for 1-2 m.y. after eruption of the Osiris Tuff and initial collapse of the caldera. The apatite age from the Dry Canyon intrusive rocks is within analytical error of the zircon date but is believed to have been reset by plugs of the younger Mount Belknap Volcanics (see section, "Silicic Intrusions") that are abundant in the area. Replacement alunite was a significant alteration mineral produced by hydrothermal activity related to intracaldera intrusions emplaced into the
Monroe Peak caldera. A new K-Ar date on replacement alunite from Marysvale Peak (sample M932) is $23.2 \pm 1.2 \mathrm{Ma}$ (table 1) and is thus numerically older than other dates of intracaldera intrusions and volcanic rocks, but it is statistically concordant.

Among several individually mapped intrusions of the Monroe Peak intracaldera sequence, the most studied is the Central intrusion (Central "intrusive" of Kerr and others, 1957) because it is host to the largest uranium deposits of the Marysvale mining district (Kerr and others, 1957; Callaghan, 1973; Cunningham and Steven, 1979a, b; Steven and others, 1981; Cunningham and others, 1982; Cunningham, Rye, and others, 1984). The intrusion is ringed by spectacularly well exposed areas of hydrothermally altered country rocks and hot-spring quartz masses, interpreted to be the tops of a series of hydrothermal convection cells of circulating ground water (Podwysocki and Segal, 1983; Cunningham, Rye, and others, 1984). The Central intrusion has been abundantly dated by various isotopic methods, although some previous isotopic determinations did not give it a satisfactory age (summarized in Rowley and others, 1988a, b). We consider the stock to be about $22 \mathrm{Ma}$ on the basis of (1) discordant fission-track dates of $23.3 \pm 2.6 \mathrm{Ma}$ (apatite) and 19.0 $\pm 0.8 \mathrm{Ma}$ (zircon) on a sample (M27A) of intrusive rock (Steven and others, 1979), and (2) more consistent K-Ar dates (Steven and others, 1979; Cunningham, Rye, and others, 1984) on replacement alunite from the surrounding advanced argillically altered rocks, namely $23.2 \pm 1.2$, $22.7 \pm 1.1,22.5 \pm 1.0$, and $21.8 \pm 4.3 \mathrm{Ma}$. The stock was emplaced at a shallow level, then eroded and unroofed by about $19 \mathrm{Ma}$, when it was unconformably overlain by the Red Hills Tuff Member of the Mount Belknap Volcanics (see section, "Mount Belknap Volcanics").

A small porphyritic rhyodacite stock (unit Trd of Cunningham and others, 1983) cuts redbeds of the Upper Triassic Chinle Formation near the base of the fault scarp preserved on the east side of the Tushar Mountains just south of the east entrance to Bullion Canyon. Sample M290 from this stock yielded a new fission-track date on zircon of $21.5 \pm 2.9 \mathrm{Ma}$ (table 2). We consider this stock to belong to the calc-alkaline sequence on the basis of a chemical analysis of the stock.

Minerals such as nepheline and corundum that are characteristic of rocks relatively rich in alkalies occur in one place in the Marysvale volcanic field, about $20 \mathrm{~km}$ southeast of Marysvale (Agrell and others, 1986). Rowley and S.O. Agrell (unpub. data, 1985) mapped the area and concluded that the rocks formed in a fine-grained, altered, nepheline syenite breccia pipe that is $1.3 \mathrm{~km}$ in maximum diameter and was emplaced into intertonguing alluvialfacies volcanic-mudflow breccia beds of the volcanic rocks of Little Table and the volcanic rocks of Langdon Mountain. New ${ }^{40} \mathrm{Ar} /{ }^{39} \mathrm{Ar}$ dating (table 3 ; fig. 4) of biotite and sanidine from a syenite vein within the breccia pipe produced disturbed spectra with the following weight-average 
Table 3. Data for ${ }^{40} \mathrm{Ar} /{ }^{39} \mathrm{Ar}$ dates ${ }^{1}$ for biotite and sanidine from sample $83-69 \mathrm{X}$, eastern Sevier Plateau, Utah.

\begin{tabular}{|c|c|c|c|c|c|c|c|}
\hline $\begin{array}{c}\text { Temp } \\
\mathrm{C}^{\circ}\end{array}$ & $\begin{array}{l}{ }^{2} \text { Radiogenic } \\
{ }^{40} \mathrm{Ar}\end{array}$ & $\begin{array}{l}{ }^{2} \mathrm{~K} \text {-derived } \\
{ }^{39} \mathrm{Ar}\end{array}$ & ${ }^{40} \mathrm{Ar}_{\mathrm{R}}{ }^{39} \mathrm{Ar}_{\mathrm{K}}{ }^{3}$ & $\begin{array}{l}\text { Radiogenic } \\
\text { yield, pct. }\end{array}$ & $\begin{array}{l}\text { Pct. }{ }^{39} \mathrm{Ar} \\
\text { of total }\end{array}$ & $\begin{array}{l}\text { Apparent } \\
\text { age (Ma) }\end{array}$ & ${ }^{4}$ Error (Ma) \\
\hline \multicolumn{8}{|c|}{ Biotite; $63.4 \mathrm{mg} ; \mathrm{J}=0.007743 \pm .25$ percent } \\
\hline 500 & 0.0121 & 0.0078 & 1.55 & 5.9 & 0.1 & 22 & \pm 12 \\
\hline 600 & .0017 & .0040 & .42 & 2.3 & 0 & 6 & \pm 18 \\
\hline 650 & .0335 & .0291 & 1.145 & 13.7 & .4 & 15.9 & \pm 0.4 \\
\hline $700+$ & .29285 & .17699 & 1.655 & 34.8 & 2.1 & 23.0 & \pm .2 \\
\hline $750+$ & .50494 & .30275 & 1.668 & 61.2 & 3.7 & 23.2 & \pm .2 \\
\hline $800+$ & 1.3649 & .81734 & 1.670 & 71.9 & 9.9 & 23.18 & $\pm \quad .07$ \\
\hline $850+$ & 2.0251 & 1.1939 & 1.696 & 79.0 & 14.4 & 23.54 & \pm .11 \\
\hline $900+$ & 2.7645 & 1.6648 & 1.661 & 87.6 & 20.1 & 23.05 & $\pm \quad .07$ \\
\hline $950+$ & 1.8314 & 1.1085 & 1.652 & 84.6 & 13.4 & 22.93 & \pm .06 \\
\hline $1000+$ & 1.3704 & .83794 & 1.635 & 71.4 & 10.1 & 22.70 & \pm .06 \\
\hline 1050 & 1.9421 & 1.1054 & 1.757 & 55.8 & 13.3 & 24.38 & \pm .07 \\
\hline 1150 & 1.8224 & .9799 & 1.860 & 36.8 & 11.8 & 25.8 & \pm .1 \\
\hline 1250 & .0897 & .0525 & 1.707 & 36.8 & .6 & 23.7 & \pm .8 \\
\hline \multicolumn{3}{|c|}{ Total-gas date } & 1.697 & & & 23.55 & \pm .13 \\
\hline \multirow{2}{*}{\multicolumn{4}{|c|}{$\begin{array}{l}\text { Weight-average date } \\
\text { Isochron date }\left[\left({ }^{40} \mathrm{Ar} /{ }^{36} \mathrm{Ar}\right)_{\mathrm{i}}=304 \pm 5\right]\end{array}$}} & & 73.7 & 23.08 & \pm .09 \\
\hline & & & & & 99.9 & 23.00 & \pm .05 \\
\hline \multicolumn{8}{|c|}{ Sanidine; $100.8 \mathrm{mg} ; \mathrm{J}=0.007637 \pm .25$ percent } \\
\hline 700 & 0.7884 & 0.4541 & 1.74 & 32.6 & 5.6 & 23.8 & \pm 2 \\
\hline $800+$ & 2.4733 & 1.4030 & 1.763 & 79.2 & 17.3 & 24.13 & \pm 0.07 \\
\hline $900+$ & 2.7986 & 1.5742 & 1.778 & 86.4 & 19.4 & 24.33 & $\pm \quad .07$ \\
\hline $950+$ & .97773 & .55155 & 1.773 & 56.6 & 6.8 & 24.26 & \pm .08 \\
\hline $1000+$ & .65416 & .36485 & 1.793 & 48.7 & 4.5 & 24.53 & \pm .18 \\
\hline $1050+$ & .72399 & .39925 & 1.813 & 54.4 & 4.9 & 24.81 & \pm .20 \\
\hline $1100+$ & .96859 & .54654 & 1.772 & 65.1 & 6.7 & 24.25 & \pm .07 \\
\hline $1150+$ & 2.7432 & 1.5364 & 1.785 & 80.1 & 18.9 & 24.43 & \pm .07 \\
\hline $1250+$ & 1.9108 & 1.0552 & 1.811 & 69.7 & 13.0 & 24.78 & \pm .10 \\
\hline 1450 & .44391 & .24143 & 1.839 & 46.8 & 3.0 & 25.16 & \pm .07 \\
\hline \multicolumn{3}{|c|}{ Total-gas date } & 1.782 & & & 24.39 & \pm .09 \\
\hline \multicolumn{3}{|c|}{ Weight-average date } & & & 91.4 & 24.40 & \pm .10 \\
\hline \multicolumn{3}{|c|}{ Isochron date $\left[\left({ }^{40} \mathrm{Ar} /{ }^{36} \mathrm{Ar}\right)_{\mathrm{i}}=294 \pm 3\right]$} & & & 100 & 24.51 & \pm .05 \\
\hline
\end{tabular}

${ }^{1}$ Analytical data for "Radiogenic ${ }^{40} \mathrm{Ar}$ " and "K-derived ${ }^{39 "}$ are calculated to five places right of the decimal; "40 $\mathrm{Ar}_{\mathrm{R}} /{ }^{39} \mathrm{Ar}_{\mathrm{K}}$ " is calculated to three places right of the decimal. "Radiogenic ${ }^{40} \mathrm{Ar}$ " and "K-derived ${ }^{39} \mathrm{Ar} "$ are rounded to significant figures using calculated analytical precisions. Apparent ages and associated errors were calculated from unrounded analytical data and then each rounded using associated errors. All analyses were done in the Argon Laboratory, USGS, Denver, Colo. Decay constants are those recommended by Steiger and Jäger (1977): $\lambda_{\varepsilon}=0.581 \times 10^{-10} / \mathrm{yr}, \lambda_{\beta-}=4.962 \times 10^{-10} / \mathrm{yr}$, and $\lambda_{=} \lambda_{\varepsilon}+\lambda_{\beta-}=5.543 \times 10^{10} / \mathrm{yr}$. The standard for this experiment is hornblende MMhb-1 with percent $\mathrm{K}=1.555,{ }^{40} \mathrm{Ar}_{\mathrm{R}}=1.624 \times 10^{-9} \mathrm{~mole} / \mathrm{g}$, and $\mathrm{K} / \mathrm{Ar}$ age $=520.4 \mathrm{Ma}$ (Samson and Alexander, 1987).

${ }^{2}$ Abundances of "Radiogenic ${ }^{40} \mathrm{Ar}$ " and "K-derived ${ }^{39} \mathrm{Ar}$ " are reported in volts. Conversion to moles can be made using $2.078 \times 10^{-12}$ moles Ar/V for sensitivity of the mass spectrometer at the time of the experiment. Detection limit at the time of this experiment was $2 \times 10^{-17}$ moles Ar measured on a Faraday detector.

${ }^{3{ }^{40}} \mathrm{Ar}_{\mathrm{R}} / 39 \mathrm{Ar}_{\mathrm{K}}$ " has been corrected for all interfering isotopes including atmospheric argon. Abundances of interfering isotopes of argon from $\mathrm{K}$ and $\mathrm{Ca}$ were calculated from reactor production ratios determined by irradiating and analyzing pure $\mathrm{CaF}_{2}$ and $\mathrm{K}_{2} \mathrm{SO}_{4}$ simultaneously with these samples. The measured production ratios are $\left({ }^{40} \mathrm{Ar} /{ }^{39} \mathrm{Ar}\right)_{\mathrm{K}}=8.78 \times 10^{-3},\left({ }^{38} \mathrm{Ar} /{ }^{39} \mathrm{Ar}\right)_{\mathrm{K}}=1.31 \times 10^{-2},\left({ }^{37} \mathrm{Ar} /{ }^{39} \mathrm{Ar}\right)_{\mathrm{K}}=1.11 \times 10^{-4},\left({ }^{36} \mathrm{Ar} /{ }^{37} \mathrm{Ar}\right)_{\mathrm{Ca}}=2.69 \times 10^{-4}$ $\left({ }^{39} \mathrm{Ar} /{ }^{37} \mathrm{Ar}\right)_{\mathrm{Ca}}=6.55 \times 10^{-4}$, and $\left({ }^{38} \mathrm{Ar} /{ }^{37} \mathrm{Ar}\right)_{\mathrm{Ca}}=3.59 \times 10^{-5}$. Corrections were also made for additional interfering isotopes of argon produced from irradiation of chlorine using the method described by Roddick (1983). Irradiation was for 30 hours at 1 megawatt in the TRIGA reactor at the USGS, Denver, Colo.

${ }^{4} 1 \sigma$ error.

+Step is used in weight-average date.

\section{SAMPLE DESCRIPTION}

83-69X. Syenite vein within breccia pipe, $10 \mathrm{~km}$ south-southwest of Greenwich, eastern Sevier Plateau: lat $38^{\circ} 21^{\prime} 37^{\prime \prime} \mathrm{N}$., long $111^{\circ} 59^{\prime} 48^{\prime \prime} \mathrm{W}$.

dates: (1) $23.1 \pm 0.1 \mathrm{Ma}$ on biotite, and (2) $24.4 \pm 0.1 \mathrm{Ma}$ on sanidine. Both age spectra show evidence of excess ${ }^{40} \mathrm{Ar}$, but because sanidine generally is a better argon geochronometer, we interpret $24.4 \pm 0.1 \mathrm{Ma}$ to be the better estimate for the emplacement age of the vein.
The Spry intrusion, defined by Anderson and Rowley (1975) and studied in somewhat greater detail by Grant and Anderson (1979), is a batholith-sized exposure of monzonitic porphyry along U.S. Highway 89 about $15 \mathrm{~km}$ south of Circleville (Anderson, Rowley, Blackman, and others, 
1990). Low-amplitude aeromagnetic anomalies (Zietz and others, 1976; Blank and Kucks, 1989) and gravity lows (Blank and Kucks, 1989; Cook and others, 1989; Viki Bankey, unpub. data, 1992) indicate that the intrusion extends $50 \mathrm{~km}$ south of its exposed part, mostly under valley-fill deposits. The body intruded into volcanics, including the volcanic rocks of Bull Rush Creek, that are believed to be its own ejecta. The intrusion arched the Claron Formation, Buckskin Breccia, and Bear Valley Formation, and it is considered to be a laccolith emplaced into the lower part of the Claron Formation, similar to other intrusions in the northern Markagunt Plateau (Anderson and Rowley, 1975; Anderson, Rowley, Machette, and others, 1990; Anderson, Rowley, Blackman, and others, 1990). A K-Ar date from plagioclase (sample 84-257) from the intrusion is $26.1 \pm 1.8$ $\mathrm{Ma}$, modified from a preliminary date on the sample published by Anderson, Rowley, Blackman, and others (1990) and given in table 1 . This date is concordant with a plagio-

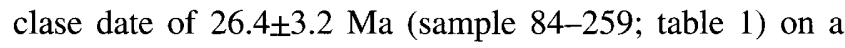
cogenetic dike cutting the volcanic rocks of Bull Rush Creek (discussed on p. 16). The actual age of some parts of the Spry intrusion may be somewhat younger than indicated by these two concordant ages because the intrusion appears to postdate at least lower parts of the Bear Valley Formation; as noted on page 16, tuff beds in the upper part of the Bear Valley have been dated at about 24.6 Ma.

The youngest known of several small laccoliths in the northern Markagunt Plateau is the Iron Peak intrusion, whose base and main body are exposed several kilometers east of Parowan. The geology of the body was summarized by Anderson and Rowley (1975), who called it the Iron Point intrusion. A K-Ar whole-rock date (sample R-28) by Fleck and others (1975) is 20.2 $\pm 0.5 \mathrm{Ma}$. Dikes probably related to the intrusion have been dated by H.H. Mehnert at about $20 \mathrm{Ma}$ (Maldonado, in press). Lava flows exposed near the body and probably derived from it, although not separated in mapping from Mount Dutton Formation (Anderson and Rowley, 1975), have an age of 21.2 Ma (see p. 12). The age of the pluton and that of its possible ejecta, however, are in some doubt because mapping in the Parowan quadrangle (Maldonado and Moore, 1993) suggests that flow breccia probably derived from the Iron Peak intrusion here is overlain by the Bauers Tuff Member (22.8 Ma) of the Condor Canyon Formation (Florian Maldonado, written commun., 1993). The laccolith may have been localized by the Red Hills shear zone (Maldonado, in press). The laccolith, which was studied in detail by Spurney (1984), is gabbro and diorite porphyry. The intrusion is more mafic than other plutons in the Marysvale field and contains noncommercial iron veinlets (Bullock, 1970). We consider the Iron Peak intrusion to mark the northeast end of the "Iron Axis" (fig. 1), a northeast-trending string of mostly quartz monzonite porphyry laccoliths that also underlie the Iron Springs and Bull Valley iron mining districts (Mackin, 1947, 1960; Blank and Mackin, 1967;
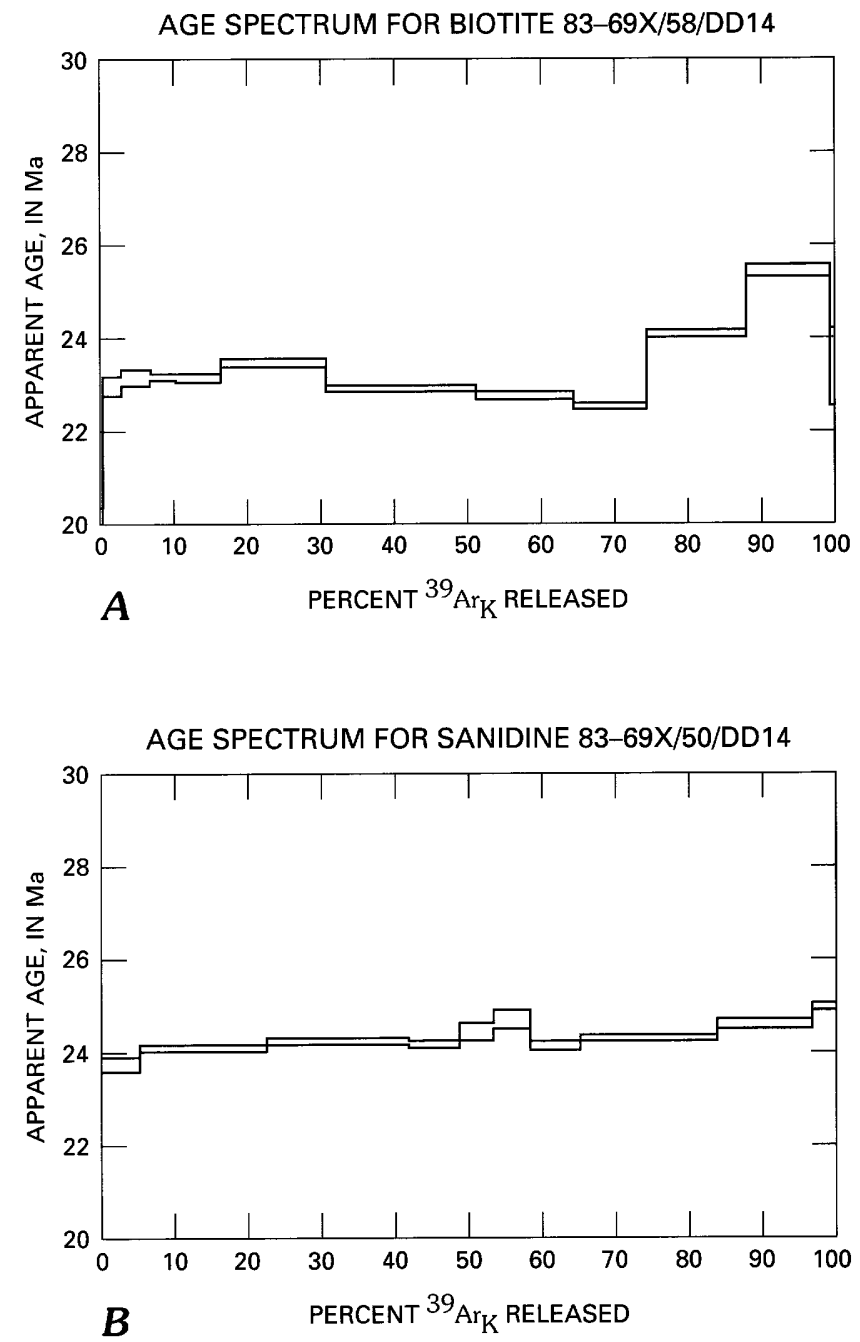

Figure 4. ${ }^{40} \mathrm{Ar} /{ }^{39} \mathrm{Ar}$ age spectrum for sample 83-69X, Marysvale volcanic field. $A$, biotite; $B$, sanidine.

Rowley and Barker, 1978; Van Kooten, 1988; Barker, 1991; Blank and others, 1992). The age of the plutons at Iron Springs appears to be about $22 \mathrm{Ma}$ (Rowley and others, 1989).

\section{UPPER CENOZOIC SEDIMENTARY AND BIMODAL IGNEOUS SEQUENCE}

\section{POTASSIUM-RICH MAFIC VOLCANIC ROCKS}

Early mapping in the southern part of the Marysvale volcanic field (Callaghan, 1939; Williams and Hackman, 1971; Anderson and Rowley, 1975) recognized basaltic rocks at two stratigraphic levels. These consist of an older sequence of "basaltic andesite" or "older basalt" lava flows, flow breccia, and conglomerate generally overlying the 
Osiris Tuff and locally intertongued with rhyolite lava flows; and a younger sequence of lithologically similar basalt lava flows, scoria, and cinder cones locally intertongued with basin-fill sedimentary rocks but generally occurring at the top of the stratigraphic column at any given location. Best and others (1980) also distinguished an older mafic rock sequence of about 25-21 Ma and younger basalt sequence of 14 Ma to Pleistocene age. They found that despite the general lithologic similarity between the two groups of rocks, the two could be distinguished geochemically: rocks of the older sequence contain $\mathrm{K}_{2} \mathrm{O}$ values generally exceeding 3 weight percent and $\mathrm{K}_{2} \mathrm{O} / \mathrm{Na}_{2} \mathrm{O}$ greater than 1 , whereas most rocks of the younger sequence are true basalt, containing significantly lower potassium values. They referred to rocks of the older sequence as potassium-rich mafic lavas, and since then, we have called them potassium-rich mafic volcanic rocks (see for example, Cunningham and others, 1983; Steven and others, 1990) except where we apply stratigraphic names to separate mappable accumulations. We conclude that the older sequence represents the first product of bimodal volcanism, which formed because of increased extensional deformation in the area. Based on the geochemistry of these potassium-rich mafic volcanic rocks (Mattox and Walker, 1989, 1990; Walker and Mattox, 1989; Mattox, 1991a, b, 1992), Mattox and Walker (1989) related the rocks to the demise of the subduction zone under western North America. Mattox (1992) disagrees somewhat with us, however, in that he finds the potassium-rich mafic rocks to be related to the termination of Mount Dutton volcanism and thus might be better included in the middle Cenozoic volcanic assemblage.

The thickest and most extensive accumulations of the potassium-rich mafic volcanic rocks are in the southern part of the Marysvale field, where some have been mapped as informally named units derived from separate local volcanic centers. The oldest are the mafic lava flows of Birch Creek Mountain (Anderson and Rowley, 1975; Anderson, Rowley, Blackman, and others, 1990), in the southern Tushar Mountains. The unit overlies the lava flows of Kents Lake, which in turn rests on the Mount Dutton Formation that contains the Osiris Tuff in its uppermost part. The mafic lava flows of Birch Creek Mountain consist of crystal-poor, olivine-bearing trachybasalt lava flows (Wickstrom, 1982) with a maximum thickness of $150 \mathrm{~m}$. Fleck and others (1975) determined two $\mathrm{K}$-Ar whole-rock dates on lava flows from the unit, 22.9 \pm 0.4 (sample R-20) and $22.4 \pm 0.4$ (sample R-17) Ma (Anderson, Rowley, Machette, and others, 1990).

Similar potassium-rich mafic flows northwest of Birch Creek Mountain (Machette and others, 1984) may correlate with the mafic lava flows of Birch Creek Mountain. One of these flows has a K-Ar whole-rock date of $23.2 \pm 0.2 \mathrm{Ma}$ (Best and others, 1980) from a sample collected on Black Mountain, $5 \mathrm{~km}$ east-southeast of Beaver. This age, however, is considered somewhat too old because the flow here overlies not only the 24-Ma Delano Peak Tuff Member of the Bullion Canyon Volcanics but also two cooling units of the 23-Ma Osiris Tuff ("tuff of Black Mountain" and "tuff of Beaver River" of Machette and others, 1984, names now abandoned) as well. The mafic flow also laps up against, and is younger than, the 22.5-Ma formation of Lousy Jim in the Beaver River drainage area. Thus, we determined a KAr whole-rock age from another sample (79-R-B) from Black Mountain; this date, first mentioned by Machette and others (1984), is $22.1 \pm 0.8 \mathrm{Ma}$ (table 1). Another new $\mathrm{K}-\mathrm{Ar}$ whole-rock date of $21.7 \pm 0.8 \mathrm{Ma}$ (table 1 ) is from another potassium-rich mafic volcanic rock (sample 79-R-A) collected from a lava flow poking through younger basin-fill sedimentary rocks $4 \mathrm{~km}$ east of Beaver (Machette and others, 1984). This last sample may correlate with the mafic lava flows of Birch Creek Mountain.

The mafic lava flows of Birch Creek Mountain are overlain by, and perhaps locally intertongued with, the mafic lava flows of Circleville Mountain (Anderson and Rowley, 1975; Anderson, Rowley, Blackman, and others, 1990). The Circleville Mountain unit consists of lava flows and flow breccia distinguished by numerous phenocrysts of plagioclase and pyroxene, which form sequences in the southeastern Tushar Mountains as thick as $350 \mathrm{~m}$. Fleck and others (1975) determined a K-Ar whole-rock date (sample R-22) of $22.8 \pm 0.4 \mathrm{Ma}$ on the unit, indicating that it is essentially contemporaneous with the mafic lava flows of Birch Creek Mountain. In the southern Tushar Mountains, another unit, which Anderson, Rowley, Machette, and others (1990) called the mafic gravels of Gunsight Flat, consists of clasts derived from the mafic lava flows of Birch Creek Mountain and Circleville Mountain and is locally intertongued with the mafic lava flows of Birch Creek Mountain. These fanglomerates and fluvial conglomerates, interpreted to be mostly shed northward from paleofault scarps, are considered to be contemporaneous with the mafic lava flows. Cunningham, Steven, Campbell, and others (1984) published a whole-rock K-Ar date of $22.8 \pm 0.7$ Ma for a sample of the mafic lava flows of Birch Creek Mountain collected where it is interbedded with the mafic gravels of Gunsight Flat (Cunningham and others, 1983).

In the northern Awapa Plateau and Fish Lake Plateau, Smith and others (1963) and Williams and Hackman (1971) mapped basaltic andesite lava flows. Some of these may be correlative with the calc-alkaline volcanic rocks of Signal Peak, but others may correlate with the potassiumrich mafic volcanic rocks. Best and others (1980), in fact, so designated a sample south of Fish Lake on which they determined a K-Ar whole-rock date of $24.5 \pm 0.5$ Ma. Fleck and others (1975) determined a K-Ar date on biotite of $22.4 \pm 0.4$ Ma for a sample (EM-1) of basaltic rock overlying Osiris Tuff in the southern Wasatch Plateau; it probably also belongs to the potassium-rich mafic volcanic rocks. Mattox (1991a) published three K-Ar plagioclase dates from "basaltic andesite" flows on the Awapa Plateau that he determined by geochemical analyses to correlate 
with the potassium-rich mafic volcanic rocks; these dates are $25.8 \pm 1.4,25.2 \pm 1.6$, and $23.2 \pm 1.5 \mathrm{Ma}$.

Elsewhere in the Marysvale volcanic field, potassiumrich mafic volcanic rocks form volumetrically smaller sequences of lava flows, reminiscent in size and scattered distribution to the younger, local sequences of basalt lava flows. (See section, "Basalt Lava Flows.") For example, in Sevier Valley near the town of Junction, potassium-rich mafic volcanic rocks as thick as $125 \mathrm{~m}$ overlie the Osiris Tuff. Wender and Nash (1979), on the basis of chemical analyses of these rocks, called them absarokite and noted that they are distinct from younger basalts. Best and others (1980) determined a K-Ar whole-rock date of $21.1 \pm 0.2 \mathrm{Ma}$ from one of these olivine-bearing flows and assigned it on the basis of chemistry to the suite of potassium-rich mafic lava flows.

\section{MOUNT BELKNAP VOLCANICS}

Increased extension in the Marysvale volcanic field led to a rise in isotherms and development of eutectic partial melts with the composition of high-silica rhyolite (C.G. Cunningham, unpub. data, 1988). The largest accumulation of volcanic rocks of the bimodal sequence, in fact, consists of high-silica rhyolite of the Mount Belknap Volcanics (Callaghan, 1939; Cunningham and Steven, 1979a; Steven and others, 1979). The formation embraces a complex assemblage of lava flows, flow breccia, volcanic mudflow breccia, volcanic domes, ash-flow tuff, and hypabyssal intrusions that were emplaced between 22 and $14 \mathrm{Ma}$ from two concurrently active eastern and western source areas that cross the central part of the volcanic field. Mount Belknap volcanism began with development of a series of crystal-rich volcanic domes and flows in the northeastern part of the eastern source area, in the Antelope Range in Sevier Valley in the western part of the older Monroe Peak caldera. Magmatism in the eastern source area resulted in hydrothermal alteration and uranium mineralization of the Central Mining Area of the Marysvale mining district. Numerous K-Ar and fission-track ages were determined on these rocks, as summarized by Rowley and others (1988a, b). Many K-Ar ages on rocks in the eastern source area determined by Bassett and others (1963) are discordant, internally and with those of other workers, and many are herein discounted. Among more reliable ages on rocks from the eastern source area are the following from a single sample of the glassy margin of the Teacup dome (Steven and others, 1979): (1) discordant fission-track dates on apatite and zircon of, respectively, $27.8 \pm 3.9$ and $20.9 \pm 1.1 \mathrm{Ma}$; and (2) $\mathrm{K}$-Ar dates on biotite of $21.6 \pm 1.1 \mathrm{Ma}$ and on sanidine of $21.6 \pm 0.9$ and $21.4 \pm 1.0 \mathrm{Ma}$. The apatite date is rejected, leaving an average age for the others of $21.4 \mathrm{Ma}$. Centers that erupted flows, domes, and tuff migrated south- westward over the next 4 m.y. The largest ash-flow tuff from the eastern source area is the Red Hills Tuff Member of the Mount Belknap Volcanics (Steven and others, 1979). It was erupted from the small Red Hills caldera near Marysvale (Cunningham and Steven, 1979a, b). The age of the Red Hills Tuff Member is $18.9 \pm 0.7 \mathrm{Ma}$ on the basis of a $\mathrm{K}$-Ar determination on sanidine (Cunningham and others, 1982). It is overlain by a series of domes and flows as much as $500 \mathrm{~m}$ thick named the Gray Hills Rhyolite Member (Steven and others, 1979). Bassett and others (1963) determined $\mathrm{K}-\mathrm{Ar}$ dates of 20.5, 20.5, and 19.5 Ma on the unit.

In the western source area, centered on the crest of the Tushar Mountains, the large Mount Belknap caldera subsided in response to eruption of the largest ash-flow tuff of the episode of bimodal magmatism, the Joe Lott Tuff Member (Steven and others, 1979; Budding and others, 1987) of the Mount Belknap Volcanics. Budding and others (1987) reported two K-Ar dates on the Joe Lott: $18.3 \pm 1.1 \mathrm{Ma}$ on sanidine from the upper cooling unit and $17.2 \pm 0.7 \mathrm{Ma}$ on hydrated basal vitrophyre of the lower cooling unit. They rejected these dates, however, and concluded that the age of the member is about $19 \mathrm{Ma}$ on the basis of isotopic ages from underlying and overlying volcanic rocks. The underlying rocks include a series of heterogeneous flows and tuff units making up the oldest rocks derived from the Mount Belknap caldera. Fission-track dates on zircon and apatite from a sample of tuff are $19.6 \pm 0.8$ and 18.8 $\pm 1.7 \mathrm{Ma}$, respectively (Steven and others, 1979). The overlying rocks include the Red Hills Tuff Member and the informally named (Steven and others, 1979) crystal-rich tuff member of the Mount Belknap Volcanics, which overlies both the Joe Lott and Red Hills Tuff Members. Two samples from the crystalrich tuff member yielded the following discordant dates (Steven and others, 1979): (1) a K-Ar date on sanidine of $18.5 \pm 0.8 \mathrm{Ma}$ and a fission-track date on zircon from the same sample of $15.3 \pm 0.8 \mathrm{Ma}$; and (2) a K-Ar date on sanidine of $19.4 \pm 0.8 \mathrm{Ma}$ and fission-track dates on zircon from the same sample of $17.1 \pm 0.8$ and $16.1 \pm 0.7 \mathrm{Ma}$; the fissiontrack dates are rejected because they are less reasonable geologically. The caldera was filled quickly by comagmatic rhyolite lava flows, breccia, ash-flow tuff, and hypabyssal rocks that are subdivided into a series of named members (Steven and others, 1979), some very thick (Cunningham and Steven, 1979b). The products of the eastern and western source areas complexly intertongue in areas between the sources. For example, the upper gray tuff member of the Mount Belknap Volcanics, considered to be the youngest identified product derived from the Mount Belknap caldera (western source area) overlies the Gray Hills Rhyolite Member (eastern source area) of the Mount Belknap Volcanics, about $5 \mathrm{~km}$ west of Marysvale; the upper gray tuff has a fission-track date on zircon of $18.0 \pm 0.8 \mathrm{Ma}$ (Steven and others, 1979). 


\section{SMALL RHYOLITE VOLCANIC CENTERS}

Small high-silica rhyolite centers synchronous with the basin-range episode of maximum extensional deformation are scattered throughout the Marysvale volcanic field. Several of these are along the east-striking Blue Ribbon lineament (fig. 1). The largest volcanic center on the lineament and the most important in terms of its tectonic implications is in the Kingston Canyon area of the southern Sevier Plateau, as first noted by Rowley (1968) and dated and discussed in detail by Rowley and others (1981). Kingston Canyon is a deep, west-flowing antecedent canyon that cuts through the Sevier Plateau, which is an east-tilted fault block uplifted on its west side more than $1,500 \mathrm{~m}$ along north-striking basin-range faults. Rhyolite flows that predate canyon cutting yielded $\mathrm{K}-\mathrm{Ar}$ dates on sanidine of $7.6 \pm 0.6 \mathrm{Ma}$ and on whole-rock obsidian of $7.6 \pm 0.4 \mathrm{Ma}$. A rhyolite volcanic dome deposited in the base of the canyon yielded K-Ar dates on sanidine of $5.4 \pm 0.3 \mathrm{Ma}$ and on whole-rock obsidian of $4.8 \pm 0.2 \mathrm{Ma}$. A basalt clast of country rock in a premonitory rhyolite tuff cone into which the dome was emplaced yielded a K-Ar whole-rock date of $7.8 \pm 0.5 \mathrm{Ma}$, indicating that basalt was emplaced at least at depth at the same time as the rhyolite flows that predated canyon cutting. Rowley and others (1981) interpreted that the cutting of Kingston Canyon indicated that the main episode of basin-range faulting in the area was between about 8 and $5 \mathrm{Ma}$.

In the Black Mountains, on the west side of the Marysvale volcanic field and farther west along the Blue Ribbon lineament, several small rhyolite centers have been dated. Two small centers, the rhyolite of Beaver airport (sample 78-1695) and the rhyolite of Teddys Valley (sample 78-1741), yielded K-Ar whole-rock obsidian dates of $8.3 \pm 0.3$ and 7.9 $\pm 0.5 \mathrm{Ma}$, respectively (Anderson, Rowley, Machette, and others, 1990); these are published again in table 1. Two other centers farther west, on the edge of the Marysvale field, are represented by the rhyolite of Blue Ribbon Summit with a K-Ar sanidine date of $7.9 \pm 0.5 \mathrm{Ma}$ (Mehnert and others, 1978; Rowley, Lipman, and others, 1978) and the rhyolite of Minersville Reservoir with an unpublished K-Ar date by S.H. Evans, Jr. of 7.5 \pm 0.3 Ma (T.A. Steven, written commun., 1984; mentioned by Evans and Steven, 1982, and Anderson, Rowley, Blackman, and others, 1990). Other rhyolites west of the Marysvale field and along the Blue Ribbon lineament were dated by Mehnert and others (1978) and Rowley, Lipman, and others (1978) and mapped by Rowley (1978).

The rhyolite of Gillies Hill is a sequence of rhyolite volcanic domes and tuff in the Great Basin (Steven and Morris, 1983; Machette and others, 1984) but north of the Blue Ribbon lineament. Evans and Steven (1982) published four biotite K-Ar dates from the volcanic center of $9.2 \pm 0.5$, $9.1 \pm 0.6,8.0 \pm 0.3$, and $7.0 \pm 0.4 \mathrm{Ma}$, and one sanidine $\mathrm{K}-\mathrm{Ar}$ date of $9.1 \pm 0.3 \mathrm{Ma}$. The rhyolite was emplaced along and postdates a major north-striking basin-range fault zone. Cunningham, Steven, Campbell, and others (1984) published a fission-track date on apatite of $8.4 \pm 0.6 \mathrm{Ma}$ from a flow in the rhyolite of Gillies Hill farther southeast, along the west scarp of the Tushar Mountains.

The rhyolite of the Mineral Mountains, at the west edge of the Marysvale field, consists of little-eroded rhyolitic tuff, flows, and volcanic domes ranging in age between 0.8 and $0.5 \mathrm{Ma}$ according to K-Ar, fission-track, and obsidian-hydration dating (Lipman and others, 1978; Mehnert and others, 1978). This Pleistocene rhyolite is a product of magmatism that today is still active under the Mineral Mountains and has been developed for commercial electrical energy in the Roosevelt geothermal area.

\section{SILICIC INTRUSIONS}

Intrusive rocks related to the eastern source area of the Mount Belknap Volcanics and to satellitic rhyolite centers of the Marysvale volcanic field are abundant. Most intrusions consist of hypabyssal rhyolite dikes and plugs that for the most part are discussed with the Mount Belknap Volcanics, but the geochronology of the stocks is summarized here. One of the smaller stocks is composed of fine-grained granodioritic to granitic rock that intruded the west side of the Central intrusion (discussed in the section, "Calc-alkaline Intrusions"), as mapped by most workers in the Central Mining Area. The stock was mapped and discussed by Rowley and others (1988a, b) as belonging to the fine-grained silicic pluton (unit Tif), and it occurs just inside the margin of the Monroe Peak caldera. Cunningham and Steven (1979a, b) interpreted the pluton to belong to the bimodal sequence and to be perhaps a source for some of the rhyolitic volcanic rocks in the eastern source area of the Mount Belknap Volcanics. Kerr and others (1957) and Rowley and others (1988a, b), however, suggested that the pluton resembles the more silicic parts of the Central intrusion and thus instead might be interpreted as a late-stage, more silicic, differentiated phase of the Central intrusion. The fine-grained silicic pluton is a host for many of the uranium ore bodies in the Central Mining Area north of Marysvale (Cunningham and Steven, 1979a). The following concordant K-Ar and fissiontrack dates were determined on samples of intrusive rocks and alteration minerals of the pluton by Steven and others (1979) and Cunningham and others (1982): (1) a fissiontrack date on zircon from the pluton of $20.2 \pm 0.9 \mathrm{Ma}$; (2) a KAr date on biotite of a dike of the fine-grained silicic pluton of $21.4 \pm 0.9 \mathrm{Ma}$ and two fission-track dates on zircon from the same sample of $21.3 \pm 0.9$ and $19.5 \pm 0.7 \mathrm{Ma}$; (3) a K-Ar date on biotite from the Central intrusion adjacent to the finegrained silicic pluton of $21.6 \pm 0.9 \mathrm{Ma}$ and a fission-track date on zircon from the same sample of $20.4 \pm 0.9 \mathrm{Ma}$ (both interpreted to be dates reset by the fine-grained silicic pluton); and (4) a fission-track date on apatite from a sample of the fine-grained silicic pluton, collected at depth in the Freedom mine, of $22.1 \pm 4.4 \mathrm{Ma}$. The average of these seven analyses 
is $20.9 \mathrm{Ma}$, our best estimate of the age of the fine-grained silicic pluton. Its age is younger than ages of even the latest volcanism in the Monroe Peak caldera, suggesting that the fine-grained silicic pluton might better be included within the bimodal sequence, as originally proposed by Cunningham and Steven (1979a, b).

A series of glassy rhyolite dikes cut the Central intrusion and fine-grained silicic pluton. These hypabyssal intrusions contain uranium- and molybdenum-bearing veins, which are interpreted to be genetically related to the intrusive activity. Cunningham and others (1982) suggested that the dikes pass downward into a hidden stock that was the primary source of the uranium in the Central Mining Area. Cunningham and Steven (1979b) also proposed, based on values of molybdenum that increase downward in mines in the Central Mining Area, that the apex of this stock may contain a porphyry-type molybdenum deposit. The following $\mathrm{K}-\mathrm{Ar}$ and fission-track determinations give the age of the glassy rhyolite dikes: (1) discordant fission-track dates on apatite and zircon from a dike sample of, respectively, $23.3 \pm 4.7$ and $18.1 \pm 0.8 \mathrm{Ma}$ (Cunningham and others, 1982); (2) a fissiontrack date on zircon of 19.0土1.0 Ma (Cunningham and others, 1982); and (3) a fission-track date on zircon from an apparent glassy dike (sample M693) of 19.9+2.0 Ma, modified from a preliminary date first published by Rowley and others (1988b) and given in table 2. Rejecting the apatite date that is numerically too old (although within analytical error of the others) yields an average age of 19.0 Ma. Cunningham and others (1982) independently arrived at a similar age by dating the effects of uranium mineralization in the Central Mining Area: (1) a U-Pb isochron date on uranium vein material of $19.0 \pm 3.7 \mathrm{Ma}$, (2) a fission-track date on quartz adjacent to pitchblende of 16.5 $\pm 4.3 \mathrm{Ma}$, and (3) K-Ar dates on two samples of sericite adjacent to veins of $21.1 \pm 0.6$ and 20.5土0.7 Ma.

A small stock of rhyolite of Mount Belknap Volcanics cuts the metamorphosed Lower Permian Toroweap Formation (Cunningham and others, 1983) near the Trinity mine, northeast of Big Rock Candy Mountain and $8 \mathrm{~km}$ north of Marysvale. A sample (M684A) yielded a new fission-track date on zircon of $19.2 \pm 2.8 \mathrm{Ma}$ (table 2).

Hypabyssal intrusions that postdate the Mount Belknap Volcanics occur locally in the Marysvale area. A small rhyolite stock named the Beaver Creek stock that intrudes the Gray Hills Rhyolite Member at the east edge of the Tushar Mountains has a fission-track date on zircon of $15.7 \pm 0.8 \mathrm{Ma}$ (Cunningham and others, 1982). About $9 \mathrm{~km}$ west of Marysvale, a rhyolite dike yielded a fission-track date on zircon of 16.6 $\pm 0.7 \mathrm{Ma}$ (Cunningham and others, 1982); it is associated with ore at the Copper Belt mine there.

The youngest igneous activity in the eastern source area of the Mount Belknap Volcanics occurred at about $14 \mathrm{Ma}$ under Alunite Ridge, about $12 \mathrm{~km}$ southwest of Marysvale in the eastern Tushar Mountains. Here a structural dome was interpreted by Cunningham and Steven (1979c) to be caused by a buried rhyolitic or granitic stock. K-Ar dates on coarsegrained vein alunite from the ridge making up the exposed top of the dome and the result of degassing of the underlying stock are $14.3 \pm 0.6$ and $13.8 \pm 0.6 \mathrm{Ma}$ (Steven and others, 1979). In addition, K-Ar dates on sericite from an underlying base-metal manto in the Deer Trail mine (Beaty and others, 1986) are 14.2 and 12.8 Ma (Bassett and others, 1963).

Igneous activity of the 22- to 14-Ma Mount Belknap magmatic episode also took place about $9 \mathrm{~km}$ north of Marysvale, where the youngest economic mineral deposit in the Central Mining Area, replacement natroalunite, formed above inferred intrusions. The main evidence for this age of magmatism comes from $\mathrm{K}-\mathrm{Ar}$ dates of natroalunite at the $\mathrm{Al}$ Kee Mee prospect of $17.7 \pm 1.0$ (Cunningham, Rye, and others, 1984) and 16.6 $\pm 0.8 \mathrm{Ma}$ (Steven and others, 1979), at the Alum King mine of 13.9 $\pm 0.9 \mathrm{Ma}$ (Cunningham, Rye, and others, 1984), and at the Big Star mine of 12.6 $\pm 2.5 \mathrm{Ma}$ (Cunningham, Rye, and others, 1984). Additional evidence comes from the new fission-track date on zircon from sample M718 of $15.3 \pm 1.4 \mathrm{Ma}$ (table 2; discussed in the section, "Monroe Peak Caldera"), which indicates a resetting of the emplacement age of the lava flows of the Monroe Peak caldera, probably related to emplacement of nearby rhyolite plugs; this date from the lava flow is modified from a preliminary one published by Rowley and others (1988b). In addition, samples from a basal glass of the rhyolite of Big Star (Cunningham and others, 1983) near the Alum King and Big Star mines gave K-Ar dates of 15.2, 14.0, and 12.0 Ma (Bassett and others, 1963); these dates indicate that volcanism also resulted from this igneous pulse.

Many features of the plutons of the Marysvale field are analogous to those exhibited by the 25- to 9-Ma Mineral Mountains batholith, which is the largest exposed batholith in Utah (Nielson and others, 1986; Steven and others, 1990; Coleman and Walker, 1992). This batholith occurs on the west side of the Marysvale volcanic field and is better exposed than most intrusive rocks elsewhere in the field. This batholith, in fact, provides a unique north-south cross section through the batholithic complex that underlies much of the Pioche-Marysvale igneous belt because the Mineral Mountains underwent huge amounts of uplift due to later (basin-range) extension associated with its formation as a core complex (Price and Bartley, 1992). Minor early phases (about $25 \mathrm{Ma}$ ) of coarse-grained quartz monzonite and granodiorite represent calc-alkaline intrusion. Later intrusive rocks became more silicic with time (Coleman and Walker, 1992). The main phase of the batholith consists of mediumgrained plutonic rocks of variable compositon, from diorite to high-silica granite, that are more alkaline than the $25-\mathrm{Ma}$ plutons (Nielson and others, 1986). These rocks formed from about 22 to $11 \mathrm{Ma}$ according to dating by Nielson and others (1986) and Aleinikoff and others (1986), or between 18 and $16 \mathrm{Ma}$ according to petrology and dating by Coleman and Walker (1992). These rocks formed during the bimodal igneous episode, although Coleman and Walker (1992) have 
considered all rocks except high-silica rhyolite of $9 \mathrm{Ma}$ to have a calc-alkaline signature, perhaps reflecting calc-alkaline source rocks that were partially melted. Rapid and extensive uplift of the range during formation as a core complex coincided with silicic intrusions of 9 Ma that fed rhyolite hypabyssal rocks and the rhyolite of Gillies Hill (Nielson and others, 1986). Pleistocene rhyolite domes, flows, and tuff (Lipman and others, 1978; Mehnert and others, 1978) are the result of later magmatism in the same area, and the west side of the range now contains geothermal energy resources. Two new $\mathrm{K}-\mathrm{Ar}$ dates published here from an intrusive rhyolite mass in the southeastern Mineral Mountains indicate that this mass is satellitic to the main mass of the Mineral Mountains batholith. The dates (sample $78-1835$ ) are $22.5 \pm 0.9 \mathrm{Ma}$ on biotite and $22.3 \pm 0.8 \mathrm{Ma}$ on sanidine (table 1).

Rhyolitic or granitic intrusions related to the western source area of the Mount Belknap Volcanics and underlying areas west of this source area are exposed in the western Tushar Mountains, as mapped by Machette and others (1984) and described by Cunningham, Steven, Campbell, and others (1984). One such intrusion is the U-Beva rhyolite stock, in the southwestern part of the Mount Belknap caldera, which yielded a fission-track date on zircon of 19.8 1.2 Ma (Cunningham, Steven, Campbell, and others, 1984). A rhyolite cone-sheet dike nearby but just outside the wall of the caldera gave a fission-track date on zircon of 20.3 $\pm 0.9 \mathrm{Ma}$ (Cunningham, Steven, Campbell, and others, 1984). These two dates represent magmatism associated with the Mount Belknap caldera. These rocks in turn are intruded by similar silicic rocks that postdate the Mount Belknap Volcanics. For example, a fission-track date on apatite from the same sample of the U-Beva stock yielded a date of $13.4 \pm 2.7 \mathrm{Ma}$, and another nearby rhyolite cone-sheet dike yielded a fission-track date on apatite of $9.5 \pm 1.9 \mathrm{Ma}$ (Cunningham, Steven, Campbell, and others, 1984). These ages indicate partial (the 13.4-Ma date) to complete (the 9.5-Ma date) resetting by a younger buried, approximately $9.5-\mathrm{Ma}$ intrusion related to the rhyolite of Gillies Hill to the west (Cunningham, Steven, Campbell, and others, 1984). Coleman and Walker (1992) noted that the youngest intrusions of the Mineral Mountains batholith date at $9 \mathrm{Ma}$, the same age as the rhyolite of Gillies Hill, and thus the latter is the extrusive equivalent of the former. The intrusive sources under the western Tushar Mountains may correlate with late phases of the Mineral Mountains batholith, and all these magmatic events are believed by Nielson and others (1986) to be synchronous with the Cove Canyon detachment fault of the southwestern Mineral Mountains and to basin-range development of the graben underlying the Beaver basin.

The Sheep Rock alunite deposit west of the U-Beva rhyolite stock, along the basin-range fault that defines the west edge of the Tushar Mountains, appears to be underlain by an intrusion, because alunite replaces rhyolite flows of the 19-Ma Mount Baldy Rhyolite Member of the Mount
Belknap Volcanics that poured over the margin of the Mount Belknap caldera. Replacement alunite from the deposit yielded $\mathrm{K}-\mathrm{Ar}$ dates of $9.4 \pm 0.5 \mathrm{Ma}$ (Steven and others, 1979) and 9.2 \pm 0.3 Ma (Cunningham, Steven, Campbell, and others, 1984). A gold deposit just north of the alunite deposit was likely localized by the same presumed hidden rhyolite or granite stock, which in turn may have been emplaced along the range-front fault, thereby suggesting that it, like the one across the Beaver basin at Gillies Hill, was active at about 9 Ma.

Inferred resetting by underlying, hidden intrusions also is exhibited by samples of the calc-alkaline Indian Creek stock, located $4 \mathrm{~km}$ west of the rim of the Mount Belknap caldera and $7 \mathrm{~km}$ northwest of the U-Beva stock. Although presumably this intrusion has an age of 24-23 Ma based on its composition and relative age, a fission-track date on zircon from the stock is $19.3 \pm 1.0 \mathrm{Ma}$, reset by an underlying intrusion probably related to Mount Belknap magmatism (Cunningham, Steven, Campbell, and others, 1984). A fission-track date on apatite from the stock is $12.8 \pm 2.1 \mathrm{Ma}$, which is interpreted to be partially reset by a still younger intrusion probably related to Gillies Hill magmatism (Cunningham, Steven, Campbell, and others, 1984). A third inferred episode of emplacement of underlying intrusions of rhyolite or granite is indicated by two fission-track zircon dates of rhyolite dikes at the Mystery Sniffer uranium mine, which is east of the Indian Creek stock and about $1 \mathrm{~km}$ west of the margin of the Mount Belknap caldera (Cunningham, Steven, Campbell, and others, 1984). The dates are 16.1 \pm 0.8 and $15.6 \pm 1.1 \mathrm{Ma}$ and suggest another hidden intrusion, with attendant hydrothermal activity (Cunningham, Steven, Campbell, and others, 1984).

\section{BASALT LAVA FLOWS}

Small fields of olivine basalt lava flows, flow breccia, and cinder cones are scattered through and around the Marysvale volcanic field (Cunningham and others, 1983; Steven and others, 1990). Vents rarely occur near either older sources of middle Cenozoic calc-alkaline igneous rocks or sources of the first (23-16 Ma) of the upper Cenozoic high-silica rhyolites; instead, they are much more common on the flanks of or beyond the Marysvale field. Some basalt vents, however, do coincide with source areas of the small fields of younger (9 Ma to Quaternary) high-silica rhyolite, suggesting that emplacement of basalt may have supplied the heat that led to partial melting of crust to form the rhyolites. Basalts overlie and intertongue with basin-fill sedimentary rocks (see next section) and generally coincide with basin-range extensional faulting. Although erosion has removed evidence of many basaltic vents, it seems that many were partly controlled by northerly-striking joints or zones of weakness related to adjacent major north-striking rangefront faults and that the basalts were deposited on the edges 
of upthrown (footwall) fault blocks, in the manner explained theoretically by Ellis and King (1991) and noted by the field data of R.E. Anderson (1988).

The southern flank of the Marysvale volcanic field and areas just south of the field contain some of the largest basalt fields in the eastern Great Basin (Anderson and Rowley, 1975) and some of the best examples of basalt louderbacks on upthrown (footwall) tilt fault blocks. These examples include basalt flows on the southern Sevier Plateau and Markagunt Plateau (Steven and others, 1990; Hintze, 1980; Moore and Nealey, 1993). The eastern flank of the Marysvale field also contains scattered basalt cinder cones and flows that cap all tilted blocks of the eastern High Plateaus (Williams and Hackman, 1971). Basalt flows also are abundant along and west of the Colorado Plateau-Great Basin boundary near the western part of the Marysvale field (Steven and Morris, 1983; Machette and others, 1984; Steven and others, 1990) and in the Black Rock Desert northwest of the Marysvale field (Steven and others, 1990).

Best and others (1980) studied the chemistry and isotopic ages of many of the true basaltic rocks throughout a broad area that ircludes the Marysvale field. Overall, dates from the basalts they analyzed from the Marysvale field range between $14 \mathrm{Ma}$ and Holocene. Histograms of isotopic ages that they published suggest three pulses of basalt magmatism in the area, at 14 to $11 \mathrm{Ma}, 9$ to $5 \mathrm{Ma}$, and 3 Ma through Quaternary. A significant basalt flow at the west end of Red Canyon, $12 \mathrm{~km}$ southeast of Panguitch, dated by Best and others (1980) at $0.6 \pm 0.1 \mathrm{Ma}$, was vertically offset between 60 and $180 \mathrm{~m}$ along the Sevier fault zone (Rowley and others, 1981). A new K-Ar whole-rock date of $5.3 \pm 0.5 \mathrm{Ma}$ (table 1) was determined on a faulted and tilted basalt lava flow (sample AC-PANG) from $1.5 \mathrm{~km}$ south-southeast of Panguitch. Anderson and Rowley (1975) compiled data on basalt occurrences from and south of the southern Marysvale field. Basalt ages between 12.6 and 0.8 Ma were published by Anderson and Mehnert (1979) from the Markagunt Plateau and areas to the southwest. Anderson and Christenson (1989) listed ages of Quaternary basalt flows in the same area. Mattox (1991a) reported two new $\mathrm{K}-\mathrm{Ar}$ whole-rock dates from the Awapa Plateau, including the oldest $(16.4 \mathrm{Ma})$ so far determined for a basalt from the Marysvale field. On the north side of the Marysvale field, two basalt flows ( 9.2 and 7.4 Ma) dated by Best and others (1980) are mentioned in the next section because they intertongue with the Sevier River Formation.

Basalt is rare in the central part of the Marysvale field. A new K-Ar whole-rock date was determined on sample M673 from the southeastern Tushar Mountains at 10.9 \pm 0.4 Ma (table 1). This date is similar to those from a basalt on the edge of the western Sevier Plateau to the east that was dated by Damon (1969) at $12.9 \pm 0.6 \mathrm{Ma}$ and by Best and others (1980) at $12.7 \pm 0.3 \mathrm{Ma}$.

\section{BASIN-FILL SEDIMENTARY ROCKS}

Grabens and related structural valleys that formed as closed basins during extension in the Great Basin and Great Basin-Colorado Plateau transition zone contain upper Cenozoic, poorly to moderately consolidated, basin-fill sedimentary rocks. Most of these sedimentary rocks are coarse- to fine-grained clastic fluvial rocks, but lacustrine rocks and airfall tuff occur locally, and in places the fluvial rocks are interbedded with basalt flows. The basins formed in large part after $10 \mathrm{Ma}$, during basin-range faulting (Zoback and others, 1981; Anderson and others, 1983; Anderson, 1989), although some clearly formed earlier as grabens or downwarps. Ages of basins differ from place to place depending on when the bounding faults or structural sags were active. Most basins in the Great Basin evolved independently, and their strata cannot be correlated from basin to basin (Anderson and others, 1983).

The Beaver basin near the west edge of the Marysvale volcanic field is a typical basin in the Great Basin that was studied in detail. The upper part of its fill is well exposed and the stratigraphy consists of local informal names (Anderson and others, 1978; Machette and others, 1984; Machette, 1985; Anderson, Rowley, Machette, and others, 1990). Dates of soil horizons, airfall tuff beds, basalt flows, and fossils constrain the stratigraphic units to the Pliocene and Quaternary (Machette, 1985). The age of beds in the lower part of the basin is not known, although the approximate 9-Ma date on the rhyolite of Gillies Hill on the north side of the basin, and the rhyolite's eruptive source interpreted to be along a basin-range fault (Evans and Steven, 1982) indicate that the Beaver basin dates at least to this time. Furthermore, in the Cedar City area south of the Beaver basin, Anderson and Mehnert (1979) determined K-Ar whole-rock ages of basalts that suggested that this basin began to form about $10 \mathrm{Ma}$.

In contrast to the many closed basins in the Great Basin, the drainages in the High Plateaus transition zone are well integrated. The name Sevier River Formation was applied by Callaghan (1938) to the sedimentary rocks of the various integrated basins throughout the area. Exposed basin-fill sedimentary rocks are at least $350 \mathrm{~m}$ thick in some basins and are well exposed in many places because rivers have cut down through the poorly consolidated sediments (Anderson and Rowley, 1975). Anderson (1987) and Rowley and others (1988a, b) summarized the geomorphic evolution of the basins and concluded that most formed independently, as in the Great Basin; these basins currently have structural relief of as much as $2,000 \mathrm{~m}$, and were formerly largely filled with sedimentary deposits, much of which have since eroded away. Most drainage systems superposed on the thick fill cut vertically through the structural margins to form deep canyons in bedrock, then integrated with streams in other basins, eroding away as much as $1,000 \mathrm{~m}$ of the fill. Some bedrock canyons, such as Kingston Canyon, are antecedent due to 
uplift of fault blocks from 8 to $5 \mathrm{Ma}$ as the river kept pace. Drainage integration continued during the Pliocene and Pleistocene.

The Sevier River Formation overlies the Joe Lott Tuff Member (19 Ma) and other units of the Mount Belknap Volcanics. Fission-track zircon dates on two tuff beds in the Sevier River Formation from near the town of Sevier, one from near the base of the formation and the other from near the eroded top, are $14.2 \pm 0.9$ and $7.1 \pm 0.7 \mathrm{Ma}$, respectively (Steven and others, 1979). West of Sevier, basalt flows interbedded with the Sevier River Formation yielded K-Ar whole-rock dates of $9.2 \pm 0.4$ and $7.4 \pm 0.7 \mathrm{Ma}$ (Best and others, 1980). The basalt flow south-southeast of Panguitch, newly dated at $5.3 \pm 0.5 \mathrm{Ma}$ and discussed in the preceding section, is probably intertongued in the upper part of the Sevier River Formation (R.E. Anderson, unpub. data, 1992).

A new K-Ar date on sanidine from an airfall tuff (sample 78-609) near the top of exposures of the Sevier River Formation on the edge of a pediment in the Sevier Valley, 11 $\mathrm{km}$ south-southeast of Marysvale, is $13.6 \pm 0.8 \mathrm{Ma}$ (table 1). This dated tuff is low in the formation and much of the overlying section has been removed by erosion, but this overlying section may have formerly filled much of the valley. Gravity data suggest that the basin fill of Sevier River Formation under the pediment is hundreds of meters thick. About $16 \mathrm{~km}$ south of Marysvale, the Sevier River Formation is similarly eroded and its exposed lower part is overlain by a basalt flow, mentioned in the preceding section, that has K-Ar whole-rock dates of $12.9 \pm 0.6 \mathrm{Ma}$ (Damon, 1969) and $12.7 \pm 0.3 \mathrm{Ma}$ (Best and others, 1980).

Another new K-Ar date of 5.6 $\pm 0.4 \mathrm{Ma}$ (table 1) was determined on sanidine from an airfall tuff (sample 80-331B) in the Sevier River Formation. This sample was collected from the base of the western scarp of the northern Sevier Plateau near Annabella, where the Sevier River Formation consists of coarse clastic sediments that represent an old fan deposit derived from the scarp. The sample thus dates part of the movement on the Sevier fault zone that formed the scarp. The date is in agreement with relationships in the Kingston Canyon area, where the main offset of the southern Sevier Plateau is documented at between 8 and 5 Ma. Anderson and Barnhard (1992) first mentioned the date but interpreted instead that the Sevier River Formation here predates fault uplift of the high Sevier Plateau along the Sevier fault zone.

\section{CONCLUSIONS}

Stratigraphic studies and compilation of new and published $\mathrm{K}-\mathrm{Ar}$, fission-track, and ${ }^{40} \mathrm{Ar} /{ }^{39} \mathrm{Ar}$ ages of Cenozoic rocks of the Marysvale volcanic field and adjacent areas of Utah show that the rocks can be placed in three stratigraphic sequences. These are the lower Cenozoic sedimentary sequence, the middle Cenozoic calc-alkaline igneous sequence, and the upper Cenozoic sedimentary and bimodal igneous sequence (fig. 2). The lower Cenozoic sedimentary sequence consists of continental sedimentary rocks whose stratigraphy is poorly known and currently under revision by other workers and by some of us. Units of this sequence include the Claron Formation and overlying Brian Head Formation. The Brian Head contains isotopically dated airfall tuff beds as old as $34 \mathrm{Ma}$ that probably represent the earliest known eruptions of the Marysvale field.

About 95 percent of the eruptive volume of the Marysvale volcanic field is represented by the middle Cenozoic calc-alkaline igneous sequence and consists of volcanic mudflow breccia and subordinate amounts of lava flows, flow breccia, and ash-flow tuff. The rocks range from basaltic andesite to low-silica rhyolite in composition and from 34(?) to $22 \mathrm{Ma}$ in age. The sequence formed during subduction beneath the western United States. Two great intertonguing units dominate the middle Cenozoic sequence: the more differentiated Bullion Canyon Volcanics (at least 32 to $22 \mathrm{Ma}$ ) in the central and northern part of the volcanic field, and the generally more mafic Mount Dutton Formation (at least 32 to $21 \mathrm{Ma}$ ) in the southern part of the field. Mapped units from smaller centers also are intertongued with these two major rock bodies. Rocks of the Bullion Canyon Volcanics and related units were derived from and overlie a major batholith complex that also extends west of the field. Intrusive rocks from this complex are exposed locally in the northern and central parts of the field, and hydrothermally altered rocks and deposits of base and precious metals resulted from them. The cover rocks above some higher intruding cupolas that developed on the batholith complex failed, and then the resulting fractures tapped major ash-flow sheets that have a cumulative volume about 10 percent of that of the massive deposits of volcanic mudflow breccia and lava flows. Tuff includes the Three Creeks Tuff Member (27 Ma) of the Bullion Canyon Volcanics that erupted from the Three Creeks caldera, the Delano Peak Tuff Member (24 Ma) of the Bullion Canyon Volcanics that erupted from the Big John caldera, and the Osiris Tuff ( $23 \mathrm{Ma}$ ) that erupted from the Monroe Peak caldera. The magma sources for the Mount Dutton Formation and related units were deeper than those of the Bullion Canyon Volcanics, and intrusive rocks related to these units are rarely exposed. In addition to regional ash-flow tuff derived from the Marysvale field, regional ash-flow units from sources in the Great Basin west of the Marysvale field are intertongued with rocks of the field. These tuff units include the Wah Wah Springs Formation (>29.5 Ma), Isom Formation (27-26 Ma), Leach Canyon Formation (24 Ma), Condor Canyon Formation (23.5-23 Ma), and Harmony Hills Tuff (22 Ma). The tuffs from within and outside the field provide regional marker horizons that assist stratigraphic subdivision of the volcanic field. 
The upper Cenozoic sedimentary and bimodal igneous sequence consists mostly of lava flows and ash-flow tuff ranging in age from 23 Ma through Quaternary. About 5 percent of the eruptive volume of the Marysvale volcanic field is represented by the upper Cenozoic bimodal igneous rocks, which consist of basaltic andesite, basalt, and rhyolite. The sequence is interpreted to represent cessation of subduction and increased extension in the western United States; the main phase of faulting is the basin-range episode of about $10 \mathrm{Ma}$ to Quaternary, which climaxed in the area at about 8 to $5 \mathrm{Ma}$. The sedimentary rocks are largely basin-fill clastic fluvial rocks deposited in basins formed probably by warping before the basin-range episode and in relatively downfaulted areas during the basin-range episode. Lava flows of potassium-rich mafic volcanic rocks, ranging in age from at least 23 to $21 \mathrm{Ma}$, generally were the first of the bimodal volcanic rocks and were derived from small centers scattered in and near the Marysvale volcanic field. The largest bimodal volcanic unit is the Mount Belknap Volcanics (23-14 Ma), which formed above a western and eastern source area spanning the central part of the Marysvale volcanic field. Intrusive rocks of the source area are exposed locally, and their intrusion resulted in hydrothermally altered rocks and deposits mostly of uranium and molybdenum. A major ash-flow sheet, the Joe Lott Tuff Member (19 Ma) of the Mount Belknap Volcanics, was erupted from the Mount Belknap caldera above the western source area. Other small rhyolite centers, as young as $0.5 \mathrm{Ma}$, are scattered throughout the Marysvale field. Basalt fields of $16 \mathrm{Ma}$ to Quaternary are likewise small and scattered throughout the Marysvale field, though basalt fields of the same age are larger outside the field.

The present mountains and valleys were formed by basin-range block faulting, especially between 8 and $5 \mathrm{Ma}$. Downthrown areas accumulated clastic sediment of the upper part of the Sevier River Formation from erosion of upthrown areas. Drainage integration, largely by rivers superposed on the basin fill, led to erosion of the soft basinfill sediments and created the present topography.

\section{REFERENCES CITED}

Agrell, S.O., Charnley, N.R., and Rowley, P.D., 1986, The occurrence of hibonite, perovskite, zirconolite, pseudobrookites and other minerals in a metamorphosed hydrothermal system at Pine Canyon, Piute County, Utah, U.S.A. [abs.]: Mineralogical Society (London) Bulletin 72, p. 4.

Aleinikoff, J.N., Nielson, D.L., Hedge, C.E., and Evans, S.H., Jr., 1986, Geochronology of Precambrian and Tertiary rocks in the Mineral Mountains, south-central Utah, Chapter A in Peterman, Z.E., and Schnabel, D.C., eds., Shorter contributions to isotope research: U.S. Geological Survey Bulletin 1622, p. $1-12$.
Anderson, J.J., 1965, Geology of northern Markagunt Plateau, Utah: Austin, Texas, University of Texas Ph. D. dissertation, $193 \mathrm{p}$.

1971, Geology of the southwestern High Plateaus of Utah-Bear Valley Formation, an Oligocene-Miocene volcanic arenite: Geological Society of America Bulletin, v. 82, p. 1179-1205.

1985, Mid-Tertiary block faulting along west and northwest trends, southern High Plateaus, Utah: Geological Society of America Abstracts with Programs, v. 17, no. 7, p. 513.

1987, Late Cenozoic drainage history of the northern Markagunt Plateau, Utah, in Kopp, R.S., and Cohenour, R.E., eds., Cenozoic geology of western Utah-Sites for precious metal and hydrocarbon accumulations: Utah Geological Association Publication 16, p. 271-278.

1988, Pre-basin-range block faulting along west and northwest trends, southeastern Great Basin and southern High Plateaus: Geological Society of America Abstracts with Programs, v. 20, no. 3, p. 139.

1993, The Markagunt megabreccia-Large Miocene gravity slides mantling the northern Markagunt Plateau, southwestern Utah: Utah Geological Survey Miscellaneous Publication 93-2, $37 \mathrm{p}$.

Anderson, J.J., Iivari, T.A., and Rowley, P.D., 1987, Geologic map of the Little Creek Peak quadrangle, Garfield and Iron Counties, Utah: Utah Geological and Mineral Survey Map 104, 11 p., scale 1:24,000.

Anderson, J.J., and Kurlich, R.A., III, 1989, Post-Claron Formation, pre-regional ash-flow tuff early Tertiary stratigraphy of the southern High Plateaus of Utah: Geological Society of America Abstracts with Programs, v. 21, no. 5, p. 50.

Anderson, J.J., and Rowley, P.D., 1975, Cenozoic stratigraphy of the southwestern High Plateaus of Utah, in Anderson, J.J., Rowley, P.D., Fleck, R.J., and Nairn, A.E.M., Cenozoic geology of southwestern High Plateaus of Utah: Geological Society of America Special Paper 160, p. 1-52.

1987, Geologic map of the Panguitch NW quadrangle, Iron and Garfield Counties, Utah: Utah Geological and Mineral Survey Map 103, 8 p., scale 1:24,000.

Anderson, J.J., Rowley, P.D., Machette, M.N., Decatur, S.H., and Mehnert, H.H., 1990, Geologic map of the Nevershine Hollow area, eastern Black Mountains, southern Tushar Mountains, and northern Markagunt Plateau, Beaver and Iron Counties, Utah: U.S. Geological Survey Miscellaneous Investigations Series Map I-1999, scale 1:50,000.

Anderson, J.J., Rowley, P.D., Blackman, J.T., Mehnert, H.H., and Grant, T.C., 1990, Geologic map of the Circleville Canyon area, southern Tushar Mountains and northern Markagunt Plateau, Beaver, Garfield, Iron, and Piute Counties, Utah: U.S. Geological Survey Miscellaneous Investigations Series Map I2000, scale 1:50,000.

Anderson, R.E., 1988, Hazard implications of joint-controlled basaltic volcanism in southwestern Utah: Geological Society of America Abstracts with Programs, v. 20, no. 7, p. A115.

1989, Tectonic evolution of the Intermontane System, Basin and Range, Colorado Plateau, and High Lava Plains, Chapter 10 in Pakiser, L.C., and Mooney, W.D., eds., Geophysical framework of the continental United States: Geological Society of America Memoir 172, p. 163-176. 
Anderson, R.E., and Barnhard, T.P., 1992, Neotectonic framework of the central Sevier Valley area, Utah, and its relationship to seismicity, in Gori, P.L., and Hays, W.W., eds., Assessment of regional earthquake hazards and risk along the Wasatch front, Utah: U.S. Geological Survey Professional Paper 1500-F, $47 \mathrm{p}$.

Anderson, R.E., Bucknam, R.C., and Hamblin, Kenneth, 1978, Road $\log$ to the Quaternary tectonics of the Intermountain Seismic Belt between Provo and Cedar City, Utah: Geological Society of America Rocky Mountain Section Annual Meeting, Field Trip 8, $50 \mathrm{p}$.

Anderson, R.E., and Christenson, G.E., 1989, Quaternary faults, folds, and selected volcanic features in the Cedar City $1^{\circ} \times 2^{\circ}$ quadrangle, Utah: Utah Geological and Mineral Survey Miscellaneous Publication 89-6, 29 p.

Anderson, R.E., and Hintze, L.F., 1993, Geologic map of the Dodge Spring quadrangle, Washington County Utah, and Lincoln County, Nevada: U.S. Geological Survey Geologic Quadrangle Map GQ-1721, scale 1:24,000.

Anderson, R.E., and Mehnert, H.H., 1979, Reinterpretation of the history of the Hurricane fault in Utah, in Newman, G.W., and Goode, H.D., eds., Basin and Range symposium: Rocky Mountain Association of Geologists and Utah Geological Association, p. 145-165.

Anderson, R.E., Zoback, M.L., and Thompson, G.A., 1983, Implications of selected subsurface data on the structural form and evolution of some basins in the northern Basin and Range province, Nevada and Utah: Geological Society of America Bulletin, v. 94, p. 1055-1072.

Armstrong, R.L., 1970, Geochronology of Tertiary igneous rocks, eastern Basin and Range province, western Utah, eastern Nevada, and vicinity, U.S.A.: Geochimica et Cosmochimica Acta, v. 34, p. 203-232.

Barker, D.S., 1991, Quartz monzonite and associated iron deposits, Iron Springs, Utah: Geological Society of America Abstracts with Programs, v. 23, no. 5, p. A388.

Bartley, J.M., Taylor, W.J., and Lux, D.R., 1992, Blue Ribbon volcanic rift in southeastern Nevada and its effects on Basin and Range fault segmentation: Geological Society of America Abstracts with Programs, v. 24, no. 6, p. 2.

Bassett, W.A., Kerr, P.F., Schaeffer, O.A., and Stoenner, R.W., 1963, Potassium-argon dating of the late Tertiary volcanic rocks and mineralization of Marysvale, Utah: Geological Society of America Bulletin, v. 74, p. 213-220.

Beaty, D.W., Cunningham, C.G., Rye, R.O., Steven, T.A., and Gonzalez-Urien, Eliseo, 1986, Geology and geochemistry of the Deer Trail $\mathrm{Pb}-\mathrm{Zn}-\mathrm{Ag}-\mathrm{Cu}$ manto deposits, Marysvale district, west-central Utah: Economic Geology, v. 81, p. 1932-1952.

Best, M.G., Christiansen, E.H., and Blank, H.R., Jr., 1989, Oligocene caldera complex and calc-alkaline tuffs and lavas of the Indian Peak volcanic field, Nevada and Utah: Geological Society of America Bulletin, v. 101, p. 1076-1090.

Best, M.G., Christiansen, E.H., Deino, A.L., Grommé, C.S., McKee, E.H., and Noble, D.C., 1989, Excursion 3A-Eocene through Miocene volcanism in the Great Basin of the western United States: New Mexico Bureau of Mines and Mineral Resources Memoir 47, p. 91-133.

Best, M.G., and Grant, S.K., 1987, Stratigraphy of the volcanic Oligocene Needles Range Group in southwestern Utah and eastern Nevada: U.S. Geological Survey Professional Paper 1433-A, 28 p.

Best, M.G., McKee, E.H., and Damon, P.E., 1980, Space-timecomposition patterns of late Cenozoic mafic volcanism, southwestern Utah and adjoining areas: American Journal of Science, v. 280, p. 1035-1050.

Best, M.G., Scott, R.B., Rowley, P.D., Swadley, W C, Anderson, R.E., Grommé, C.S., Harding, A.E., Deino, A.L., Christiansen, E.H., Tingey, D.G., and Sullivan, K.R., 1993, OligoceneMiocene caldera complexes, ash-flow sheets, and tectonism in the central and southeastern Great Basin, in Lahren, M.M., Trexler, J.H., Jr., and Spinosa, Claude, eds., Crustal evolution of the Great Basin and Sierra Nevada: Cordilleran/Rocky Mountain section, Geological Society of America Guidebook, Dept. of Geological Sciences, University of Nevada, Reno, p. 285-311.

Best, M.G., Shuey, R.T., Caskey, C.F., and Grant, S.K., 1973, Stratigraphic relations of members of the Needles Range Formation at type localities in southwestern Utah: Geological Society of America Bulletin, v. 84, p. 3269-3278.

Blackman, J.T., 1985, Geology of a vent of the Mount Dutton Formation (Miocene), southwest Tushar Mountains, Utah: Kent, Ohio, Kent State University M.S. thesis, 80 p.

Blank, H.R., Jr., 1959, Geology of the Bull Valley district, Washington County, Utah: Seattle, Wash., University of Washington Ph. D. dissertation, $177 \mathrm{p}$.

Blank, H.R., and Kucks, R.P., 1989, Preliminary aeromagnetic, gravity, and generalized geologic maps of the USGS Basin and Range-Colorado Plateau transition zone study area in southwestern Utah, southeastern Nevada, and northwestern Arizona (the "BARCO" project): U.S. Geological Survey Open-File Report 89-432, 16 p.

Blank, H.R., Jr., and Mackin, J.H., 1967, Geologic interpretation of an aeromagnetic survey of the Iron Springs district, Utah: U.S. Geological Survey Professional Paper 516-B, 14 p.

Blank, H.R., Rowley, P.D., and Hacker, D.B., 1992, Miocene monzonitic intrusions and associated megabreccias of the Iron Axis region, southwestern Utah, in Wilson, J.R., ed., Field guide to geologic excursions in Utah and adjacent areas of Nevada, Idaho, and Wyoming, Geological Society of America Rocky Mountain Section Meeting: Utah Geological Survey Miscellaneous Publication 92-3, p. 399-420.

Bowers, W.E., 1972, The Canaan Peak, Pine Hollow, and Wasatch Formations in the Table Cliff Region, Garfield County, Utah: U.S. Geological Survey Bulletin 1331-B, 39 p.

1990, Geologic map of Bryce Canyon National Park and vicinity, southwestern Utah: U.S. Geological Survey Miscellaneous Investigations Series Map I-2108, 15 p., scale 1:24,000.

Budding, K.E., Cunningham, C.G., Zielinski, R.A., Steven, T.A., and Stern, C.R., 1987, Petrology and chemistry of the Joe Lott Tuff Member of the Mount Belknap Volcanics, Marysvale volcanic field, west-central Utah: U.S. Geological Survey Professional Paper 1354, 47 p.

Bullock, K.C., 1970, Iron deposits of Utah: Utah Geological and Mineralogical Survey Bulletin 88, $101 \mathrm{p}$.

Callaghan, Eugene, 1938, Preliminary report on the alunite deposits of the Marysvale region, Utah: U.S. Geological Survey Bulletin 886-D, p. 91-134. 
1939, Volcanic sequence in the Marysvale region in southwest-central Utah: American Geophysical Union Transactions, 20th Annual Meeting, Washington, D.C., pt. 3, p. 438-452.

1973, Mineral resources potential of Piute County, Utah and adjoining area: Utah Geological and Mineralogical Survey Bulletin 102, $135 \mathrm{p}$.

Callaghan, Eugene, and Parker, R.L., 1961a, Geology of the Monroe quadrangle, Utah: U.S. Geological Survey Geologic Quadrangle Map GQ-155, scale 1:62,500.

$1961 \mathrm{~b}$, Geologic map of part of the Beaver quadrangle, Utah: U.S. Geological Survey Mineral Investigations Map MF-202, scale 1:62,500.

1962a, Geology of the Delano Peak quadrangle, Utah: U.S. Geological Survey Geologic Quadrangle Map GQ-153, scale $1: 62,500$.

1962b, Geology of the Sevier quadrangle, Utah: U.S. Geological Survey Geologic Quadrangle Map GQ-156, scale $1: 62,500$.

Campbell, D.L., Cunningham, C.G., Steven, T.A., Rowley, P.D., Glassgold, L.B., and Anderson, J.J., 1984, Aeromagnetic map on a geologic base map of the Tushar Mountains and adjoining areas, Marysvale volcanic field, Utah: U.S. Geological Survey Miscellaneous Investigations Series Map I-1430-D, scale 1:50,000.

Carpenter, B.S., and Reimer, G.M., 1974, Calibrated glass standards for fission-track use: National Bureau of Standards Special Publication 260-49, p. 1-16.

Caskey, C.F., and Shuey, R.T., 1975, Mid-Tertiary volcanic stratigraphy, Sevier-Cove Fort area, central Utah: Utah Geology, v. 2, no. 1, p. 17-25.

Christiansen, R.L., and Lipman, P.W., 1972, Cenozoic volcanism and plate-tectonic evolution of the western United States-II. Late Cenozoic: Philosophical Transactions of Royal Society of London, v. A271, p. 249-284.

Coleman, D.S., and Walker, J.D., 1992, Evidence for the generation of juvenile granitic crust during continental extension, Mineral Mountains batholith, Utah: Journal of Geophysical Research, v. 97, no. B7, p. 11,011-11,024.

Cook, K.L., Bankey, Viki, Mabey, D.R., and DePanger, Michael, 1989, Complete Bouguer gravity anomaly map of Utah: Utah Geological and Mineral Survey Map 122, scale 1:500,000.

Cook, K.L., Halliday, M.E., Cunningham, C.G., Steven, T.A., Rowley, P.D., Glassgold, L.B., Anderson, J.J., and Coles, L.L., 1984, Complete Bouguer gravity anomaly map on a geologic base map of the Tushar Mountains and adjoining areas, Marysvale volcanic field, Utah: U.S. Geological Survey Miscellaneous Investigations Series Map I-1430-C, scale 1:50,000.

Cunningham, C.G., Ludwig, K.R., Naeser, C.W., Weiland, E.K., Mehnert, H.H., Steven, T.A., and Rasmussen, J.D., 1982, Geochronology of hydrothermal uranium deposits and associated igneous rocks in the eastern source area of the Mount Belknap Volcanics, Marysvale, Utah: Economic Geology, v. 77, no. 2, p. $453-463$.

Cunningham, C.G., Rye, R.O., Steven, T.A., and Mehnert, H.H., 1984, Origins and exploration significance of replacement and vein-type alunite deposits in the Marysvale volcanic field, west-central Utah: Economic Geology, v. 79, p. 50-71.

Cunningham, C.G., and Steven, T.A., 1979a, Mount Belknap and Red Hills calderas and associated rocks, Marysvale volcanic field, west-central Utah: U.S. Geological Survey Bulletin 1468,34 p.

1979b, Uranium in the Central Mining Area, Marysvale district, west central Utah: U.S. Geological Survey Miscellaneous Investigations Series Map I-1177, scale 1:24,000.

1979c, Geologic map of the Deer Trail Mountain-Alunite Ridge mining area, west-central Utah: U.S. Geological Survey Miscellaneous Investigations Series Map I-1230, scale 1:24,000.

Cunningham, C.G., Steven, T.A., Rowley, P.D., Glassgold, L.B., and Anderson, J.J., 1983, Geologic map of the Tushar Mountains and adjoining areas, Marysvale volcanic field, Utah: U.S. Geological Survey Miscellaneous Investigations Series Map I-1430-A, scale 1:50,000.

1984, Map of argillic and advanced argillic alteration and principal hydrothermal quartz and alunite veins in the Tushar Mountains and adjoining areas, Marysvale volcanic field, Utah: U.S. Geological Survey Miscellaneous Investigations Series Map I-1430-B, scale 1:50,000.

Cunningham, C.G., Steven, T.A., Campbell, D.L., Naeser, C.W., Pitkin, J.A., and Duval, J.S., 1984, Multiple episodes of igneous activity, mineralization, and alteration in the western Tushar Mountains, Marysvale volcanic field, west-central Utah, Chapter A in Steven, T.A., ed., Igneous activity and related ore deposits in the western and southern Tushar Mountains, Marysvale volcanic field, west-central Utah: U.S. Geological Survey Professional Paper 1299, p. 1-22.

Damon, P.E., 1969, Correlation and chronology of ore deposits and volcanic rocks: Tucson, Ariz., Arizona University, Geochronology Laboratory, U.S. Atomic Energy Commission Contract AT(11-1)-689, Annual Progress Report COO-689-120, 90 p.

Davis, G.H., and Krantz, R.W., 1986, Post-"Laramide" thrust faults in the Claron Formation, Bryce Canyon National Park, Utah: Geological Society of America Abstracts with Programs, v. 18, no. 5, p. 98 .

Dutton, C.E., 1880, Report on the geology of the High Plateaus of Utah with atlas: U.S. Geographical and Geological Survey, Rocky Mountain region (Powell), 307 p.

Ekren, E.B., Bucknam, R.C., Carr, W.J., Dixon, G.L., and Quinlivan, W.D., 1976, East-trending structural lineaments in central Nevada: U.S. Geological Survey Professional Paper 986, 16 p.

Ellis, Michael, and King, Geoffrey, 1991, Structural control of flank volcanism in continental rifts: Science, v. 254, p. 839-842.

Evans, S.H., Jr., and Steven, T.A., 1982, Rhyolites in the Gillies Hill-Woodtick Hill area, Beaver County, Utah: Geological Society of America Bulletin, v. 93, p. 1131-1141.

Evernden, J.F., and Curtis, G.H., 1965, The present status of potassium-argon dating of Tertiary and Quaternary rocks: International Association of Quaternary Research, 6th Congress, Warsaw, 1961, Report, v. 1, p. 643-651.

Fleck, R.J., Anderson, J.J., and Rowley, P.D., 1975, Chronology of mid-Tertiary volcanism in High Plateaus region of Utah, in Anderson, J.J., Rowley, P.D., Fleck, R.J., and Nairn, A.E.M., Cenozoic geology of southwestern High Plateaus of Utah: Geological Society of America Special Paper 160, p. 53-62.

Gleadow, A.J.W., Hurtford, A.J., and Quaife, R.D., 1976, Fission track dating of zircon-Improved etching techniques: Earth and Planetary Science Letters, v. 33, p. 273-276. 
Goldstrand, P.M., 1990, Stratigraphy and paleogeography of Late Cretaceous and Paleogene rocks of southwest Utah: Utah Geological and Mineral Survey Miscellaneous Publication 90-2, $58 \mathrm{p}$.

1992, Evolution of Late Cretaceous and early Tertiary basins of southwest Utah based on clastic petrology: Journal of Sedimentary Petrology, v. 62, no. 3, p. 495-507.

Grant, T.C., and Anderson, J.J., 1979, Geology of the Spry intrusion, Garfield County, Utah: Utah Geology, v. 6, p. 5-24.

Gregory, H.E., 1951, The geology and geography of the Paunsaugunt region, Utah: U.S. Geological Survey Professional Paper $226,116 \mathrm{p}$.

Hintze, L.F., 1980, Geologic map of Utah: Utah Geological and Mineral Survey, scale 1:500,000.

-1986, Stratigraphy and structure of the Beaver Dam Mountains, southwestern Utah, in Griffen, D.T., and Phillips, W.R., eds., Thrusting and extensional structures and mineralization in the Beaver Dam Mountains, southwestern Utah: Utah Geological Association Publication 15, p. 1-36.

Kerr, P.F., Brophy, G.P., Dahl, H.M., Green, Jack, and Woolard, L.E., 1957, Marysvale, Utah, uranium area-Geology, volcanic relations, and hydrothermal alteration: Geological Society of America Special Paper 64, 212 p.

Kowallis, B.J., and Best, M.G., 1990, Fission track ages from volcanic rocks in southwestern Utah and southeastern Nevada: Isochron/West, no. 55, p. 24-27.

Kurlich, R.A., III, and Anderson, J.J., 1991, Preliminary geologic map of the Hatch 7.5 minute quadrangle, Garfield County, southwestern Utah: U.S. Geological Survey Open-File Report 91-37, 7 p., scale 1:24,000.

-in press, Geologic map of the Hatch quadrangle, Garfield County, Utah: Utah Geological Survey Map, scale 1:24,000.

Lanigan, J.C., Jr., and Anderson, J.J., 1987, Geology of the lower canyon of Beaver River, southwestern Tushar Mountains, Utah, in Kopp, R.S., and Cohenour, R.E., eds., Cenozoic geology of western Utah-Sites for precious metal and hydrocarbon accumulations: Utah Geological Association Publication 16, p. $417-428$.

LaRocque, A., 1960, Molluscan faunas of the Flagstaff Formation of central Utah: Geological Society of America Memoir 78, $100 \mathrm{p}$.

Le Bas, M.J., LeMaitre, R.W., Streckeisen, A., and Zanettin, B., 1986, A chemical classification of volcanic rocks based on the total alkali-silica diagram: Journal of Petrology, v. 27, pt. 3, p. $745-750$.

Lipman, P.W., 1992, Magmatism in the Cordilleran United States-Progress and problems, in Burchfiel, B.C., Lipman, P.W., and Zoback, M.L., eds., The Cordilleran orogen-Conterminous U.S.: Geological Society of America, The geology of North America, v. G-3, p. 481-514.

Lipman, P.W., Prostka, H.J., and Christiansen, R.L., 1972, Cenozoic volcanism and plate-tectonic evolution of the western United States-I. Early and middle Cenozoic: Philosophical Transactions of the Royal Society of London, v. A.271, p. 217-248.

Lipman, P.W., Rowley, P.D., Mehnert, H.H., Evans, S.H., Jr., Nash, W.P., and Brown, F.H., 1978, Pleistocene rhyolite of the Mineral Mountains, Utah-Geothermal and archeological significance, with sections on Fission-track dating, by Izett, G.A., and Naeser, C.W., and on Obsidian-hydration dating, by Irving
Friedman: U.S. Geological Survey Journal of Research, v. 6, no. 1, p. $133-147$.

Lundin, E.R., 1989, Thrusting of the Claron Formation, Bryce Canyon region, Utah: Geological Society of America Bulletin, v. 101, p. 1038-1050.

Lundin, E.R., and Davis, G.H., 1987, Southeast vergent thrust faulting and folding of the Eocene(?) Claron Formation, Bryce Canyon National Park, Utah: Geological Society of America Abstracts with Programs, v. 19, no. 5, p. 317.

Machette, M.N., 1985, Late Cenozoic geology of the Beaver basin, southwestern Utah: Brigham Young University Studies in Geology, v. 32, pt. 1, p. 19-37.

Machette, M.N., Steven, T.A., Cunningham, C.G., and Anderson, J.J., 1984, Geologic map of the Beaver quadrangle, Beaver and Piute Counties, Utah: U.S. Geological Survey Miscellaneous Investigations Series Map I-1520, scale 1:50,000.

Mackin, J.H., 1947, Some structural features of the intrusions in the Iron Springs district: Utah Geological Society Guidebook 2, $62 \mathrm{p}$.

-1960 , Structural significance of Tertiary volcanic rocks in southwestern Utah: American Journal of Science, v. 258, p. 81-131.

Mackin, J.H., and Rowley, P.D., 1976, Geologic map of the Three Peaks quadrangle, Iron County, Utah: U.S. Geological Survey Geologic Quadrangle Map GQ-1297, scale 1:24,000.

Maldonado, Florian, in press, Decoupling of mid-Tertiary rocks, Red Hills-western Markagunt Plateau, southwestern Utah, Chapter I, in Scott, R.B., and Swadley, W C, eds., Geologic studies in the Basin and Range-Colorado Plateau transition in southeastern Nevada, southwestern Utah, and northwestern Arizona, 1992: U.S. Geological Survey Bulletin 2056.

Maldonado, Florian, and Moore, R.C., 1993, Preliminary geologic map of the Parowan quadrangle, Iron County, Utah: U.S. Geological Survey Open-File Report 93-3, 9 p., scale 1:24,000.

Maldonado, Florian, Sable, E.G., and Anderson, J.J., 1989, Evidence for shallow detachment faulting of mid-Tertiary rocks, Red Hills (Basin and Range), with implications for a more extensive detachment zone in the adjacent Markagunt Plateau (Colorado Plateau), southwest Utah [abs]: Eos, v. 70, no. 43, p. 1336.

1990, Shallow detachment of mid-Tertiary rocks, Red Hills (Basin and Range), with implications for a regional detachment zone in the adjacent Markagunt Plateau (Colorado Plateau), southwest Utah: Geological Society of America Abstracts with Programs, v. 22, no. 3, p. 63.

-1992, Evidence for a Tertiary low-angle shear zone, Red Hills, with implications for a regional shear zone in the adjacent Colorado Plateau, in Harty, K.M., ed., Engineering \& environmental geology of southwestern Utah: Utah Geological Association Publication 21, p. 315-323.

Maldonado, Florian, and Williams, V.S., 1993a, Geologic map of the Parowan Gap quadrangle, Iron County, Utah: U.S. Geological Survey Geologic Quadrangle Map GQ-1712, scale $1: 24,000$.

1993b, Geologic map of the Paragonah quadrangle, Iron County, Utah: U.S. Geological Survey Geologic Quadrangle Map GQ-1713, scale 1:24,000.

Mattox, S.R., 1991a, Origin of potassium-rich mafic lava flows, Marysvale volcanic field, Utah: Eos, Program and Abstracts, v. 72 , no. 44 , p. 561 . 
1991b, Petrology, age, geochemistry, and correlation of the Tertiary volcanic rocks of the Awapa Plateau, Garfield, Piute, and Wayne Counties, Utah: Utah Geological Survey Miscellaneous Publication 91-5, 46 p.

-1992, Geochemistry, origin, and tectonic implications of mid-Tertiary and late Tertiary and Quaternary volcanic rocks, southern Marysvale volcanic field, Utah: DeKalb, Ill., Northern Illinois University $\mathrm{Ph}$. D. dissertation, $502 \mathrm{p}$.

Mattox, S.R., and Walker, J.A., 1989, Geochemistry and tectonism of lavas erupted during the transition from compression to extension, southern Marysvale complex, southwestern Utah: IAVCEI Abstracts, New Mexico Bureau of Mines and Mineral Resources Bulletin 131, p. 178.

-1990, Late Cenozoic lavas of the Utah transition zone: Geological Society of America Abstracts with Programs, v. 22, no. 3, p. 65.

Mehnert, H.H., Rowley, P.D., and Lipman, P.W., 1978, K-Ar ages and geothermal implications of young rhyolites in west-central Utah: Isochron/West, no. 21, p. 3-7.

Merle, O.R., Davis, G.H., Nickelsen, R.P., and Gourlay, P.A., 1993, Relation of thin-skinned thrusting of Colorado Plateau strata in southwestern Utah to Cenozoic magmatism: Geological Society of America Bulletin, v. 105, p. 387-398.

Miller, W.R., Motooka, J.M., Cunningham, C.G., Steven, T.A., Rowley, P.D., and Anderson, J.J., 1984a, Distribution of anomalous trace elements in the nonmagnetic fraction of heavy-mineral concentrates of stream sediments, shown on a geologic base map of the Tushar Mountains and adjoining areas, Marysvale volcanic field, Utah: U.S. Geological Survey Miscellaneous Investigations Series Map I-1430-E, scale 1:50,000.

1984b, Distribution of anomalous trace elements in the magnetic fraction of heavy-mineral concentrates of stream sediments, shown on a geologic base map of the Tushar Mountains and adjoining areas, Marysvale volcanic field, Utah: U.S. Geological Survey Miscellaneous Investigations Series Map I-1430-F, scale 1:50,000.

$-1984 \mathrm{c}$, Distribution of anomalous trace elements in the lessthan-180-micrometer fraction of stream sediments, shown on a geologic base map of the Tushar Mountains and adjoining areas, Marysvale volcanic field, Utah: U.S. Geological Survey Miscellaneous Investigation Series Map I-1430-G, scale 1:50,000.

Moore, D.W., and Nealey, L.D., 1993, Preliminary geologic map of the Navajo Lake quadrangle, Kane and Iron Counties, Utah: U.S. Geological Survey Open-File Report 93-190, 16 p.

Mullett, D.J.,1989, Interpreting the early Tertiary Claron Formation of southern Utah: Geological Society of America Abstracts with Programs, v. 21, no. 5, p. 120.

Mullett, D.J., Wells, N.A., and Anderson, J.J., 1988a, Early Cenozoic deposition in the Cedar-Bryce depocenter-Certainties, uncertainties, and comparisons with other Flagstaff-Green River Basins: Geological Society of America Abstracts with Programs, v. 20, no. 3, p. 217.

-1988b, Unusually intense pedogenic modification of the Paleocene-Eocene Claron Formation of southwestern Utah: Geological Society of America Abstracts with Programs, v. 20, no. 5 , p. 382.

Naeser, C.W., 1976, Fission track dating: U.S. Geological Survey Open-File Report 76-190, 65 p.
1979, Fission-track dating and geologic annealing of fission tracks, in Jäger, Emile, and Hunziker, J.C., eds., Lectures in isotope geology: New York, Springer-Verlag, p. 154-169.

Nelson, S.T., Davidson, J.P., and Sullivan, K.R., 1992, New age determinations of central Colorado Plateau laccoliths, Utah-Recognizing disturbed $\mathrm{K}$-Ar systematics and re-evaluating tectonomagmatic relationships: Geological Society of America Bulletin, v. 104, p. 1547-1560.

Nickelsen, R.P., and Merle, O., 1991, Structural evolution at the tip line of a mid-Tertiary compressional event in southwestern Utah: Geological Society of America Abstracts with Programs, v. 23, no. 1, p. 109.

Nielson, D.L., Evans, S.H., Jr., and Sibbett, B.S., 1986, Magmatic, structural, and hydrothermal evolution of the Mineral Mountains intrusive complex, Utah: Geological Society of America Bulletin, v. 97, p. 765-777.

Noble, D.C., and McKee, E.H., 1972, Description and K-Ar ages of volcanic units of the Caliente volcanic field, Lincoln County, Nevada, and Washington County, Utah: Isochron/West, no. 5, p. 17-24.

Parsons, W.H., 1965, Structures and origin of volcanic rocks, Montana-Wyoming-Idaho, in National Science Foundation Guidebook, Summer Conference, 1965: Detroit, Mich., Wayne State University, $58 \mathrm{p}$.

1969, Criteria for the recognition of volcanic breccia-Review, in Igneous and metamorphic geology (Poldervaart volume): Geological Society of America Memoir 115, p. 263-304.

Podwysocki, M.H., and Segal, D.B., 1983, Mapping of hydrothermally altered rocks using air-borne multispectral data, Marysvale, Utah, mining district: Economic Geology, v. 78, p. 675-687.

Price, D.E., and Bartley, J.M., 1992, Three-dimensional extensional structure of the southern Mineral Mountains, southwestern Utah: Geological Society of America Abstracts with Programs, v. 24 , no. 6 , p. 58 .

Roddick, J.C., 1983, High precision intercalibration of ${ }^{40} \mathrm{Ar} /{ }^{39} \mathrm{Ar}$ standards: Geochimica et Cosmochimica Acta, v. 47, p. 887-898.

Rowley, P.D., 1968, Geology of the southern Sevier Plateau, Utah: Austin, Texas, University of Texas Ph. D. dissertation, 340 p.

1978, Geologic map of the Thermo 15-minute quadrangle, Beaver and Iron Counties, Utah: U.S. Geological Survey Geologic Quadrangle Map GQ-1493, scale 1:62,500.

Rowley, P.D., Anderson, J.J., Williams, P.L., and Fleck, R.J., 1978, Age of structural differentiation between the Colorado Plateaus and Basin and Range provinces in southwestern Utah: Geology, v. 6, p. 51-55.

Rowley, P.D., Anderson, R.E., Snee, L.W., and Mehnert, H.H., 1990, Geology and structural setting of the western Caliente caldera complex, Lincoln County, Nevada: Geological Society of America Abstracts with Programs, v. 22, no. 3, p. 79.

Rowley, P.D., and Barker, D.S., 1978, Geology of the Iron Springs mining district, Utah, in Shawe, D.R., and Rowley, P.D., eds., Guidebook to mineral deposits of southwestern Utah: Utah Geological Association Publication 7, p. 49-58.

Rowley, P.D., Cunningham, C.G., Anderson, J.J., and Steven, T.A., 1979, Geologic map of the Marysvale SW quadrangle, Piute County, Utah: U.S. Geological Survey Miscellaneous Field Studies Map MF-1116, scale 1:24,000. 
Rowley, P.D., Cunningham, C.G., Steven, T.A., Mehnert, H.H., and Naeser, C.W., 1988a, Geologic map of the Marysvale quadrangle, Piute County, Utah: Utah Geological and Mineral Survey Map 105, 15 p., scale 1:24,000.

1988b, Geologic map of the Antelope Range quadrangle, Sevier and Piute Counties, Utah: Utah Geological and Mineral Survey Map 106, 14 p., scale 1:24,000.

Rowley, P.D., Hereford, Richard, and Williams, V.S., 1987, Geologic map of the Adams Head-Johns Valley area, southern Sevier Plateau, Garfield County, Utah: U.S. Geological Survey Miscellaneous Investigations Series Map I-1798, scale 1:50,000.

Rowley, P.D., Lipman, P.W., Mehnert, H.H., Lindsey, D.A., and Anderson, J.J., 1978, Blue Ribbon lineament, an east-trending structural zone within the Pioche mineral belt of southwestern Utah and eastern Nevada: U.S. Geological Survey Journal of Research, v. 6, no. 2, p. 175-192.

Rowley, P.D., McKee, E.H., and Blank, H.R., Jr., 1989, Miocene gravity slides resulting from emplacement of the Iron Mountain pluton, southern Iron Springs mining district, Iron County, Utah [abs.]: Eos, v. 70, no. 43, p. 1309.

Rowley, P.D., Nealey, L.D., Unruh, D.M., Snee, L.W., Mehnert, H.H., Anderson, R.E., and Grommé, C.S., in press, Stratigraphy of Oligocene and Miocene ash-flow tuffs in and near the Caliente caldera complex, southeastern Nevada and southwestern Utah, Chapter B in Scott, R.B., and Swadley, W C, eds., Geologic studies in the Basin and Range-Colorado Plateau transition in southeastern Nevada, southwestern Utah, and northwestern Arizona, 1992: U.S. Geological Survey Bulletin 2056.

Rowley, P.D., Shroba, R.R., Simonds, F.W., Burke, K.J., Axen, G.J., and Olmore, S.D., in press, Geologic map of the Chief Mountain quadrangle, Lincoln County, Nevada: U.S. Geological Survey Geologic Quadrangle Map GQ-1731, scale $1: 24,000$.

Rowley, P.D., and Siders, M.A., 1988, Miocene calderas of the Caliente caldera complex, Nevada-Utah [abs.]: Eos, v. 69, no. 44, p. 1508.

Rowley, P.D., Snee, L.W., Mehnert, H.H., Anderson, R.E., Axen, G.J., Burke, K.J., Simonds, F.W., Shroba, R.R., and Olmore, S.D., 1992, Structural setting of the Chief mining district, eastern Chief Range, Lincoln County, Nevada, Chapter H in Thorman, C.H., ed., Application of structural geology to mineral and energy resources of the central and western United States: U.S. Geological Survey Bulletin 2012, 17 p.

Rowley, P.D., Steven, T.A., and Mehnert, H.H., 1981, Origin and structural implications of upper Miocene rhyolites in Kingston Canyon, Piute County, Utah: Geological Society of America Bulletin, pt. I, v. 92, p. 590-602.

Rowley, P.D., Steven, T.A., Anderson, J.J., and Cunningham, C.G., 1979, Cenozoic stratigraphic and structural framework of southwestern Utah: U.S. Geological Survey Professional Paper 1149,22 p.

Rowley, P.D., Williams, P.L., and Kaplan, A.M., 1986a, Geologic map of the Greenwich quadrangle, Piute County, Utah: U.S. Geological Survey Geologic Quadrangle Map GQ-1589, scale 1:24,000.

-1986b, Geologic map of the Koosharem quadrangle, Sevier and Piute Counties, Utah: U.S. Geological Survey Geologic Quadrangle Map GQ-1590, scale 1:24,000.
Sable, E.G., and Anderson, J.J., 1985, Tertiary tectonic slide megabreccia, Markagunt Plateau, southwestern Utah: Geological Society of America Abstracts with Programs, v. 17, no. 4, p. 263.

Samson, S.D., and Alexander, E.C., Jr., 1987, Calibration of the interlaboratory ${ }^{40} \mathrm{Ar} /{ }^{39} \mathrm{Ar}$ dating standard, MMhb-1: Chemical Geology, v. 66, p. 27-34.

Schneider, M.C., 1967, Early Tertiary continental sediments of central and south-central Utah: Brigham Young University Geology Studies, v. 14, p. 143-194.

Scott, R.B., Grommé, C.S., Best, M.G., Rosenbaum, J.G., and Hudson, M.R., in press, Stratigraphic relationships of Tertiary volcanic rocks in central Lincoln County, southeastern Nevada, Chapter A in Scott, R.B., and Swadley, W C, eds., Geologic studies in the Basin and Range-Colorado Plateau transition in southeastern Nevada, southwestern Utah, and northwestern Arizona, 1992: U.S. Geological Survey Bulletin 2056.

Siders, M.A., and Shubat, M.A., 1986, Stratigraphy and structure of the northern Bull Valley Mountains and Antelope Range, Iron County, Utah, in Griffen, D.T., and Phillips, W.R., eds., Thrusting and extensional structures and mineralization in the Beaver Dam Mountains, southwestern Utah: Utah Geological Association Publication 15, p. 87-102.

Sigmund, J.M., 1979, Geology of a Miocene rhyodacite lava flow, southern Tushar Mountains, Utah: Kent, Ohio, Kent State University M.S. thesis, $35 \mathrm{p}$.

Smedes, H.W., and Prostka, H.J., 1973, Stratigraphic framework of the Absaroka Volcanic Supergroup in the Yellowstone National Park region: U.S. Geological Survey Professional Paper 729-C, $33 \mathrm{p}$.

Smith, J.F., Jr., Huff, L.C., Hinrichs, E.N., and Luedke, R.G., 1963, Geology of the Capitol Reef area, Wayne and Garfield Counties, Utah: U.S. Geological Survey Professional Paper 363, $102 \mathrm{p}$.

Spurney, J.C., 1984, Geology of the Iron Peak intrusion, Iron County, Utah: Kent, Ohio, Kent State University M.S. thesis, $84 \mathrm{p}$.

Steiger, R.H., and Jäger, Emile, 1977, Subcommission on geochronology - Convention on the use of decay constants in geo- and cosmochronology: Earth and Planetary Science Letters, v. 36, p. 359-362.

Steven, T.A., 1981, Three Creeks caldera, southern Pavant Range, Utah: Brigham Young University Geology Studies, v. 28, pt. 3, p. $1-7$.

1988, Mosaic faulting as a guide to mineral exploration in the Richfield $1^{\circ} \times 2^{\circ}$ quadrangle, western Utah, in Schindler, K.S., ed., USGS research on mineral resources-1989 program and abstracts: U.S. Geological Survey Circular 1035, p. 71.

Steven, T.A., Cunningham, C.G., and Anderson, J.J., 1984, Geologic history and uranium potential of the Big John caldera, southern Tushar Mountains, Utah, Chapter B in Steven, T.A., ed., Igneous activity and related ore deposits in the western and southern Tushar Mountains, Marysvale volcanic field, westcentral Utah: U.S. Geological Survey Professional Paper 1299, p. 25-33.

Steven, T.A., Cunningham, C.G., and Machette, M.N., 1981, Integrated uranium systems in the Marysvale volcanic field, westcentral Utah, in Goodell, P.C., and Waters, A.C., eds., Uranium in volcanic and volcaniclastic rocks: American Association of Petroleum Geologists Studies in Geology 13, p. 111-122. 
Steven, T.A., Cunningham, C.G., Naeser, C.W., and Mehnert, H.H., 1979, Revised stratigraphy and radiometric ages of volcanic rocks and mineral deposits in the Marysvale area, west-central Utah: U.S. Geological Survey Bulletin 1469, 40 p.

Steven, T.A., and Morris, H.T., 1983, Geologic map of the Cove Fort quadrangle, west-central Utah: U.S. Geological Survey Miscellaneous Investigations Map I-1481, scale 1:50,000.

1987, Summary mineral resource appraisal of the Richfield $1^{\circ} \times 2^{\circ}$ quadrangle, west-central Utah: U.S. Geological Survey Circular 916, 24 p.

Steven, T.A., Morris, H.T., and Rowley, P.D., 1990, Geologic map of the Richfield $1^{\circ} \times 2^{\circ}$ quadrangle, west-central Utah: U.S. Geological Survey Miscellaneous Investigations Series Map I-1901, scale 1:250,000.

Steven, T.A., Rowley, P.D., and Cunningham, C.G., 1984, Calderas of the Marysvale volcanic field, west central Utah: Journal of Geophysical Research, v. 89, no. B10, p. 8751-8764.

Streckeisen, A., 1976, To each plutonic rock its proper name: Earth Science Reviews, v. 12, p. 1-33.

Sullivan, K.R., Kowallis, B.J., and Mehnert, H.H., 1991, Isotopic ages of igneous intrusions in southeastern Utah-Evidence for a mid-Cenozoic Reno-San Juan magmatic zone: Brigham Young University Geology Studies, v. 37, p. 139-144.

Taylor, W.J., Bartley, J.M., Lux, D.R., and Axen, G.J., 1989, Timing of Tertiary extension in the Railroad Valley-Pioche transect, Nevada-Constraints from ${ }^{40} \mathrm{Ar} /{ }^{39} \mathrm{Ar}$ ages of volcanic rocks: Journal of Geophysical Research, v. 94, p. 7757-7774.

Van Kooten, G.K., 1988, Structure and hydrocarbon potential beneath the Iron Springs laccolith, southwestern Utah: Geological Society of America Bulletin, v. 100, no. 10, p. 1533-1540.

Walker, J.A., and Mattox, S.R., 1989, The influences of subduction on mid-late Cenozoic volcanism in southwestern Utah: Geological Society of America Abstracts with Programs, v. 21, no. 6, p. A57.
Wender, L.E., and Nash, W.P., 1979, Petrology of Oligocene and early Miocene calc-alkaline volcanism in the Marysvale area, Utah: Geological Society of America Bulletin, pt. II, v. 90, p. 34-76.

Wickstrom, L.H., 1982, Geology of a Miocene felsic tuff and overlying basalts, southwestern Tushar Mountains, Utah: Kent, Ohio, Kent State University M.S. thesis, 61 p.

Wiley, M.A., 1963, Stratigraphy and structure of the Jackson Mountain-Tobin Wash area, southwest Utah: Austin, Texas, University of Texas M.S. thesis, 104 p.

Willard, M.E., and Callaghan, Eugene, 1962, Geology of the Marysvale quadrangle, Utah: U.S. Geological Survey Geologic Quadrangle Map GQ-154, scale 1:24,000.

Williams, P.L., 1967, Stratigraphy and petrography of the Quichapa Group, southwestern Utah and southeastern Nevada: Seattle, Wash., University of Washington $\mathrm{Ph}$. D. dissertation, $182 \mathrm{p}$.

Williams, P.L., and Hackman, R.J., 1971, Geology, structure, and uranium deposits of the Salina quadrangle, Utah: U.S. Geological Survey Miscellaneous Geologic Investigations Map I-591, scale $1: 250,000$.

Willis, G.C., 1985, Revisions to the geochronology and source areas of early Tertiary formations in the Salina area of Sevier Valley, central Utah: Geological Society of America Abstracts with Programs, v. 17, no. 4, p. 272.

Yannacci, D.S., 1986, The Buckskin Breccia-A block and ashflow tuff of Oligocene age in the southwestern High Plateaus of Utah: Kent, Ohio, Kent State University M.S. thesis, 107 p.

Zietz, Isidore, Shuey, Ralph, and Kirby, J.R., Jr., 1976, Aeromagnetic map of Utah: U.S. Geological Survey Geophysical Investigations Map GP-907, scale 1:1,000,000.

Zoback, M.L., Anderson, R.E., and Thompson, G.A., 1981, Cainozoic evolution of the state of stress and style of tectonism in the Basin and Range province of the western United States: Royal Society of London Philosophical Transactions, v. A300, p. $407-434$.
Published in the Central Region, Denver, Colorado

Manuscript approved for publication September 24, 1993

Edited by Lorna Carter

Graphics prepared by Mari L. Kauffmann

Photocomposition by Carol A. Quesenberry 


\section{SELECTED SERIES OF U.S. GEOLOGICAL SURVEY PUBLICATIONS}

\section{Periodicals}

Earthquakes \& Volcanoes (issued bimonthly).

Preliminary Determination of Epicenters (issued monthly).

\section{Technical Books and Reports}

Professional Papers are mainly comprehensive scientific reports of wide and lasting interest and importance to professional scientists and engineers. Included are reports on the results of resource studies and of topographic, hydrologic, and geologic investigations. They also include collections of related papers addressing different aspects of a single scientific topic.

Bulletins contain significant data and interpretations that are of lasting scientific interest but are generally more limited in scope or geographic coverage than Professional Papers. They include the results of resource studies and of geologic and topographic investigations; as well as collections of short papers related to a specific topic.

Water-Supply Papers are comprehensive reports that present significant interpretive results of hydrologic investigations of wide interest to professional geologists, hydrologists, and engineers. The series covers investigations in all phases of hydrology, including hydrology, availability of water, quality of water, and use of water.

Circulars present administrative information or important scientific information of wide popular interest in a format designed for distribution at no cost to the public. Information is usually of short-term interest.

Water-Resources Investigations Reports are papers of an interpretive nature made available to the public outside the formal USGS publications series. Copies are reproduced on request unlike formal USGS publications, and they are also available for public inspection at depositories indicated in USGS catalogs.

Open-File Reports include unpublished manuscript reports, maps, and other material that are made available for public consultation at depositories. They are a nonpermanent form of publication that may be cited in other publications as sources of information.

\section{Maps}

Geologic Quadrangle Maps are multicolor geologic maps on topographic bases in $71 / 2$ - or 15-minute quadrangle formats (scales mainly $1: 24,000$ or $1: 62,500$ ) showing bedrock, surficial, or engineering geology. Maps generally include brief texts; some maps include structure and columnar sections only.

Geophysical Investigations Maps are on topographic or planimetric bases at various scales, they show results of surveys using geophysical techniques, such as gravity, magnetic, seismic, or radioactivity, which reflect subsurface structures that are of economic or geologic signifcance. Many maps include correlations with the geology.

Miscellaneous Investigations Series Maps are on planimetric or topographic bases of regular and irregular areas at various scales; they present a wide variety of format and subject matter. The series also includes 7 1/2-minute quadrangle photogeologic maps on planimetric bases which show geology as interpreted from aerial photographs. The series also includes maps of Mars and the Moon.
Coal Investigations Maps are geologic maps on topographic or planimetric bases at various scales showing bedrock or surficial geology, stratigraphy, and structural relations in certain coal-resource areas.

Oil and Gas Investigations Charts show stratigraphic information for certain oil and gas fields and other areas having petroleum potential.

Miscellaneous Field Studies Maps are multicolor or black-andwhite maps on topographic or planimetric bases on quadrangle or irregular areas at various scales. Pre-1971 maps show bedrock geology in relation to specific mining or mineral-deposit problems; post-1971 maps are primarily black-and-white maps on various subjects such as environmental studies or wilderness mineral investigations.

Hydrologic Investigations Atlases are multicolored or black-andwhite maps on topographic or planimetric bases presenting a wide range of geohydrologic data of both regular and irregular areas; the principal scale is $1: 24,000$, and regional studies are at $1: 250,000$ scale or smaller.

\section{Catalogs}

Permanent catalogs, as well as some others, giving comprehensive listings of U.S. Geological Survey publications are available under the conditions indicated below from USGS Map Distribution, Box 25286, Building 810, Denver Federal Center, Denver, CO 80225. (See latest Price and Availability List.)

"Publications of the Geological Survey, 1879-1961" may be purchased by mail and over the counter in paperback book form and as a set microfiche.

"Publications of the Geological Survey, 1962-1970" may be purchased by mail and over the counter in paperback book form and as a set of microfiche.

"Publications of the U.S. Geological Survey, 1971-1981" may be purchased by mail and over the counter in paperback book form (two volumes, publications listing and index) and as a set of microfiche.

Supplements for 1982, 1983, 1984, 1985, 1986, and for subsequent years since the last permanent catalog may be purchased by mail and over the counter in paperback book form.

State catalogs, "List of U.S. Geological Survey Geologic and Water-Supply Reports and Maps For (State)," may be purchased by mail and over the counter in paperback booklet form only.

"Price and Availability List of U.S. Geological Survey Publications," issued annually, is available free of charge in paperback booklet form only.

Selected copies of a monthly catalog "New Publications of the U.S. Geological Survey" is available free of charge by mail or may be obtained over the counter in paperback booklet form only. Those wishing a free subscription to the monthly catalog "New Publications of the U.S. Geological Survey" should write to the U.S. Geological Survey, $582 \mathrm{Na}$ tional Center, Reston, VA 22092.

Note.-Prices of Government publications listed in older catalogs, announcements, and publications may be incorrect. Therefore, the prices charged may differ from the prices in catalogs, announcements, and publications. 
